\title{
On lymphedema of the lower limbs after treatment of endometrial cancer \\ -with emphasis on incidence, quality of life, risk factors and health economy
}

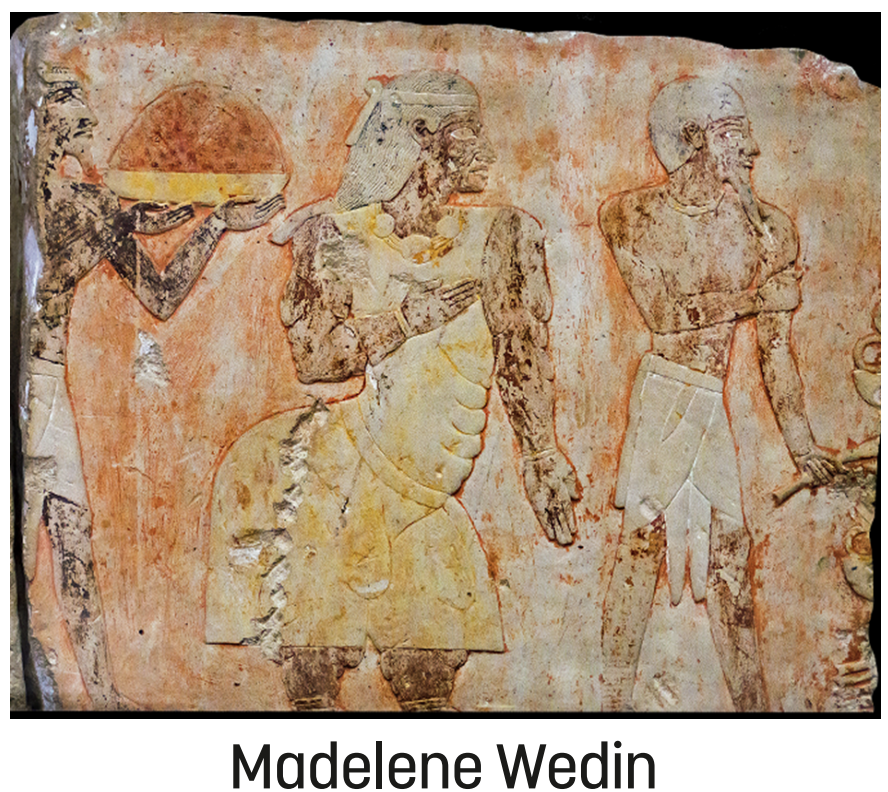



Linköping University Medical Dissertation

No. 1777

\section{On lymphedema of the lower limbs after treatment of endometrial cancer}

-with emphasis on incidence, quality of life, risk factors, and health economy

Madelene Wedin

10U UNNIERSTITES

Department of biomedical and clinical sciences, Division of Children's and Women's Health

Linköping University, Linköping, Sweden

Linköping 2021 
$($ (c) EY This work is licensed under a Creative Commons Attribution 4.0 International License.

https://creativecommons.org/licenses/by/4.0

Front illustration "Princess Ati of Egypt" reprinted by the license CC-BY-SA.

On lymphedema of the lower limbs after treatment of endometrial cancer

- with emphasis on incidence, quality of life, risk factors, and health economy

(C) Madelene Wedin, 2021

ISBN 978-91-7929-663-6

ISSN 0345-0082

Printed in Sweden by LiU-Tryck, 2021 
To all the women who have survived endometrial cancer and suffer from lymphedema 



\section{Abstract}

Objectives: The overall purpose of this study was to investigate the long-term consequences of primary surgical treatment of endometrial cancer with emphasis on lymphadenectomy, lymphedema development in the limbs, health-related quality of life, and health economy aspects. The primary objective was to assess the incidence of lymphedema both objectively and subjectively by using three different methods to determine lymphedema. Secondary objectives were to determine risk factors for lymphedema, and to analyze the impact of lymphadenectomy and lymphedema on health-related quality of life. Another secondary objective was to evaluate the hospital costs of lymphadenectomy and lymphedema one year after primary treatment of endometrial cancer.

Material and methods: The study was a prospective observational longitudinal multicenter study with 15 Swedish hospitals participating between June 2014 and January 2018. Two hundred sixty-two women with presumed early stage endometrial cancer were included; 235 women completed the study. Of these, 119 were classified as having high-risk endometrial cancer and underwent surgery including lymphadenectomy, and 116 were classified as having low-risk endometrial cancer where no lymphadenectomy was performed. The women were evaluated preoperatively according to the national guidelines for endometrial cancer. The women were all monitored on four occasions: preoperatively, then four to six weeks, six months, and one year postoperatively. On all occasions, lymphedema was evaluated by means of two objective methods: systematic circumferential measurements of the lower limbs, enabling estimation of the leg volume, and by clinical grading of lymphedema of the lower limbs, and subjectively by means of the patient-reported perception of leg swelling. Health-related quality of life was evaluated using three different quality of life questionnaires. Two were generic: the SF-36 and EQ-5D-3L, and one was lymphedema-specific: the LYMQOL. Intraabdominal lymphocysts were evaluated by transvaginal ultrasound. Cost analysis of hospital costs was performed in relation to lymphadenectomy and lymphedema development.

Results: The incidence of lymphedema varied between $9.5 \%$ and $29.6 \%$, depending on the method of assessment of lymphedema. The highest incidence was found when using patientreported swelling. The incidences of lymphedema were significantly higher in the lymphadenectomy group $(14.9 \%-38.1 \%)$ compared with the non-lymphadenectomy group $(3.4 \%-21.4 \%)$. The inter-rater agreement of lymphedema between the various methods of determining lymphedema was low. The incidence of lymphocysts was $4.3 \%$ and did not seem to pose a clinical problem. Lymphadenectomy per se did not seem to affect health-related quality of life negatively; however, lymphedema, independent of the method of assessing lymphedema, affected the lymphedema-specific quality of life significantly negatively, mainly in physical domains. Lymphadenectomy, age, and adjuvant radiation therapy were independent risk factors for lymphedema. Lymphadenectomy generated higher hospital costs, independent of the mode of surgery.

Conclusions: A significant number of women develop lymphedema after lymphadenectomy in the treatment of endometrial cancer. The incidences vary, depending on the method of determining lymphedema. This inconsistency is also reflected in risk factors for lymphedema. Lymphadenectomy, increasing age, and adjuvant radiation are factors to pay attention to when planning treatment of endometrial cancer, not least because lymphedema has a negative impact on health-related quality of life. Lymphadenectomy is a cost-driving procedure and its use should be carefully evaluated in relation to its potential benefit 



\section{List of Scientific papers}

I. Incidence of lymphedema in the lower limbs and lymphocyst formation within one year of surgery for endometrial cancer: A prospective longitudinal multicenter study. Madelene Wedin, Karin Stålberg, Janusz Marcickiewicz, Eva Ahlner, Åsa Åkesson, Gabriel Lindahl, Preben Kjølhede. Gynecol Oncol. 2020;159(1):201-8.

II. Impact of lymphadenectomy and lymphoedema on health-related quality of life 1 year after surgery for endometrial cancer. A prospective longitudinal multicentre study.

Madelene Wedin, Karin Stålberg, Janusz Marcickiewicz, Eva Ahlner, Åsa Åkesson, Gabriel Lindahl, Ninnie Borendal Wodlin, Preben Kjølhede. BJOG. 2021 Aug 26. Online ahead of print.

III. Risk factors for lymphedema and method of assessment in endometrial cancer: a prospective longitudinal multicenter study.

Madelene Wedin, Karin Stålberg, Janusz Marcickiewicz, Eva Ahlner, Ulrika Ottander, Åsa Åkesson, Gabriel Lindahl, Ninnie Borendal Wodlin, Preben Kjølhede. Int J Gynecol Cancer. 2021 Oct 5:ijgc-2021-002890. Online ahead of print.

IV. Cost analysis of lymphadenectomy and lymphedema one year after surgery of endometrial cancer.

Madelene Wedin, Thomas Davidson, Evelyn Lundin, Karin Stålberg, Janusz Marcickiewicz, Gabriel Lindahl, Ninnie Borendal Wodlin, Preben Kjølhede. In manuscript.

The published papers are reprinted with permission from the publishers 


\section{Abbreviations}

\begin{tabular}{|c|c|}
\hline $\mathrm{AB}$ & Aortic bifurcation \\
\hline $\mathrm{AD}$ & Anno Domini \\
\hline ANOVA & Analysis of variance \\
\hline $\mathrm{aOR}$ & Adjusted odds ratio \\
\hline ASA & American Society of Anesthesiologists \\
\hline $\mathrm{BP}$ & Bodily pain \\
\hline $\mathrm{BC}$ & Before Christ \\
\hline BIA & Bioelectrical impedance \\
\hline BMI & Body mass index \\
\hline BMI-SV & Body mass index-standardized volume increase \\
\hline BSOE & Bilateral salpingo-oophorectomy \\
\hline $\mathrm{CI}$ & Confidence interval \\
\hline $\mathrm{CPP}$ & Cost per patient \\
\hline $\mathrm{CT}$ & Computed tomography \\
\hline DCIV & Deep circumflex iliac vein. \\
\hline SNGEC & The Swedish National Guidelines for treatment of endometrial cancer \\
\hline EBV & Estimated bleeding volume \\
\hline EC & Endometrial cancer \\
\hline EQ-5D-3L & The EuroQol group five dimension and three-level form \\
\hline FIGO & The International Federation of Gynecology and Obstetrics \\
\hline GCP & Good clinical practice \\
\hline $\mathrm{GH}$ & General health perception \\
\hline HRQoL & Health-related quality of life \\
\hline ICH-GCP & International Conference on Harmonisation -Good Clinical practice \\
\hline IMA & Inferior mesenteric artery \\
\hline IQR & Interquartile range \\
\hline LA & Lymphadenectomy \\
\hline LRV & Left renal vein \\
\hline LYMQOL & Lymphedema quality of life questionnaire \\
\hline $\mathrm{MCS}$ & Mental component summery \\
\hline $\mathrm{MH}$ & Mental health \\
\hline MRI & Magnetic resonance imaging \\
\hline NSAID & Non-steroidal anti-inflammatory drug \\
\hline PACU & Post anesthesia care unit \\
\hline PCS & Physical component summary \\
\hline $\mathrm{PF}$ & Physical functioning \\
\hline QALY & Quality-adjusted life-years \\
\hline QoL & Quality of life \\
\hline RE & Role limitations due to emotional problems \\
\hline $\mathrm{RP}$ & Physical problems \\
\hline SD & Standard deviation \\
\hline SEK & Swedish Crowns \\
\hline $\mathrm{SF}$ & Social functioning \\
\hline SF-36 & The 36-item Short Form Health Survey \\
\hline SNGEC & Swedish National Guidelines for Endometrial Cancer \\
\hline STROBE & STrengthening the Reporting of OBservational studies in Epidemiology \\
\hline $\mathrm{TH}$ & Total hysterectomy \\
\hline TSV & Transvaginal sonography \\
\hline WHO & The World Health Organization \\
\hline VT & Vitality \\
\hline
\end{tabular}




\section{Contents}

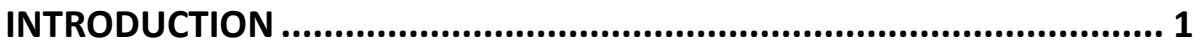

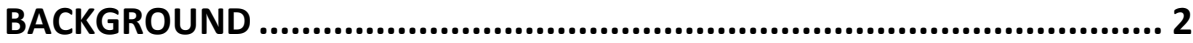

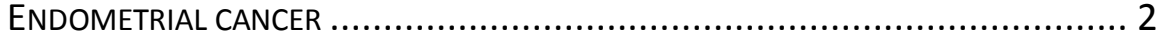

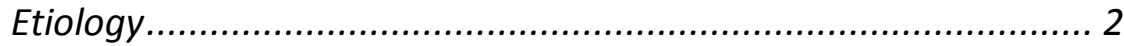

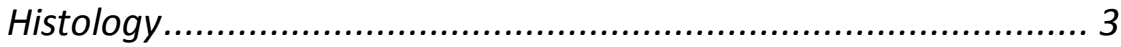

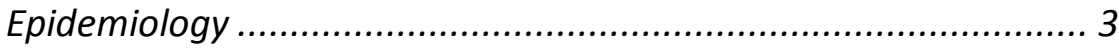

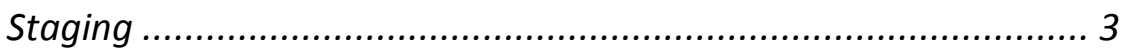

Pre-treatment evaluation ............................................................ 4

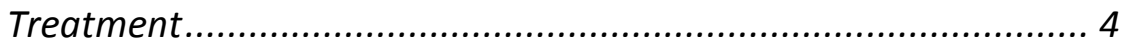

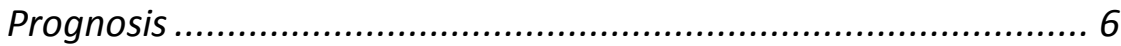

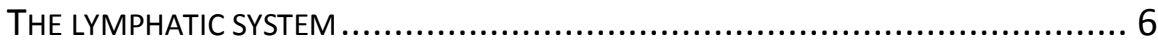

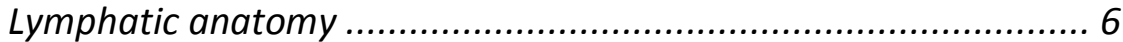

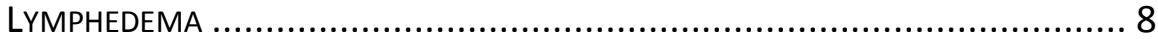

Lymphedema in a historic perspective ....................................... 9

Pathophysiology of lymphedema ............................................ 11

Risk factors for lymphedema ................................................ 14

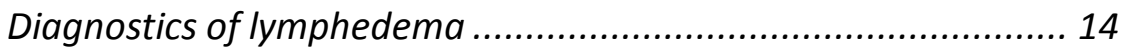

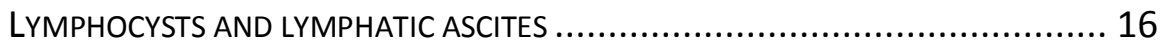

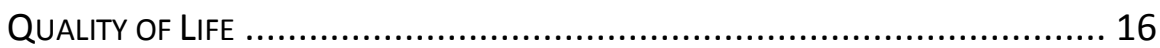

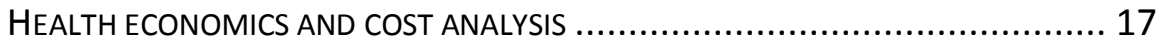

CLINICAL CONSIDERATIONS AND EVOLVEMENT OF HYPOTHESES..... 19

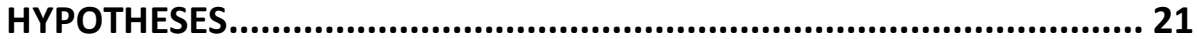

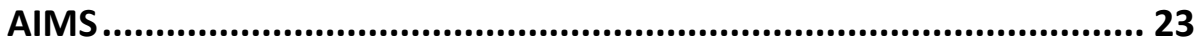

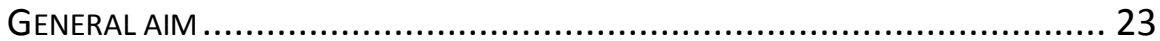

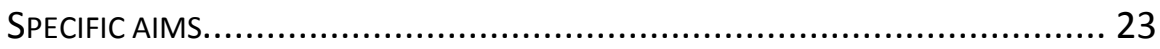

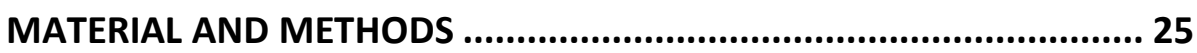

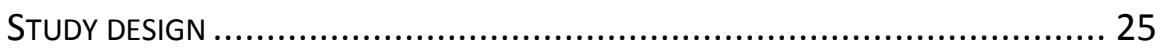

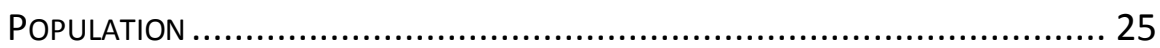

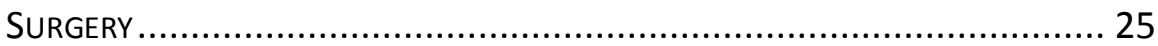

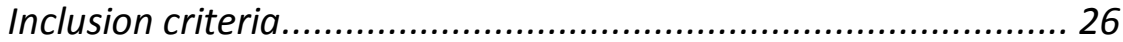

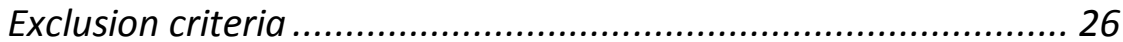


ADJUVANT ONCOLOGICAL TREATMENT ......................................... 26

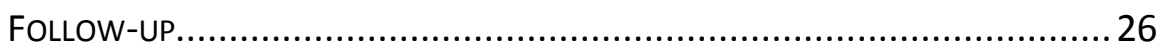

METHODS OF ASSESSING LYMPHEDEMA ........................................ 26

Leg volume measurement............................................ 27

Clinical evaluation of the legs ......................................... 28

Patient's perception of leg swelling ..................................... 29

ASSESSMENT OF LYMPHOCYST AND LYMPHATIC ASCITES......................... 29

QUALITY ASSESSMENT OF THE LASEC TRIAL .................................. 29

HEALTH-RELATEd QuAlity OF LIFE ASSESSMENTS................................ 29

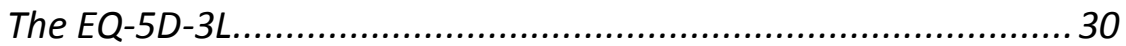

The SF-36......................................................... 30

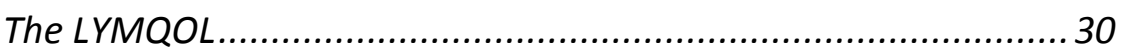

HEALTH ECONOMY ......................................................... 31

Hospital costs ........................................................... 31

ETHICAL APPROVAL AND CONSIDERATIONS................................... 35

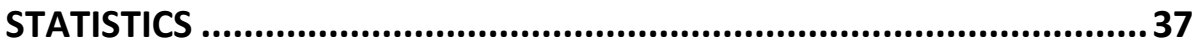

SAMPLE SIZE ESTIMATION OF THE LASEC TRIAL .................................. 37

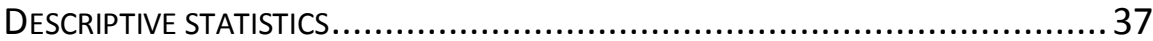

COMPARATIVE STATISTICS ................................................... 37

RESULTS AND COMMENTS................................................... 39

DESCRIPTION OF STUDY POPULATION ......................................... 39

Distribution according to hospital and lymphadenectomy .......... 42

Reliability of leg measurements.................................... 42

Measurements and clinical grading of legs ......................... 43

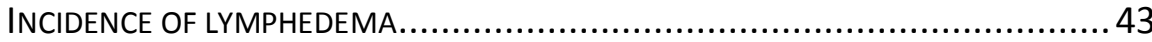

Assessing leg volume over time in relation to lymphadenectomy. 45

Assessing clinical grading of lymphedema over time.................. 48

Assessing the patient-reported leg swelling over time .............. 50

AGREEMENT BETWEEN METHODS OF DETERMINING LYMPHEDEMA ................. 52

RISK FACTORS FOR LYMPHEDEMA .......................................... 54

LYMPHOCYST AND LYMPHATIC ASCITES ................................... 59

IMPACT OF LYMPHADENECTOMY ON HRQOL....................................60

Generic HRQoL measures.............................................. 60 
Lymphedema-specific HRQoL measures ................................... 62

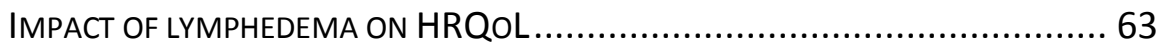

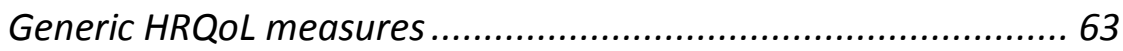

Lymphedema-specific HRQoL measures ................................... 65

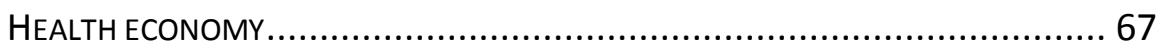

Hospital costs in relation to lymphadenectomy......................... 67

Hospital costs in relation to lymphedema ............................... 70

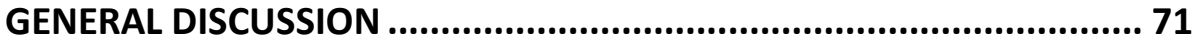

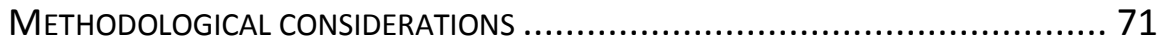

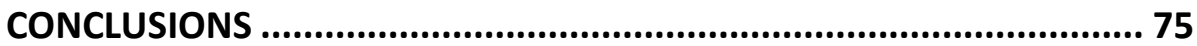

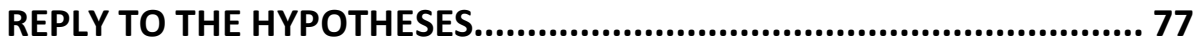

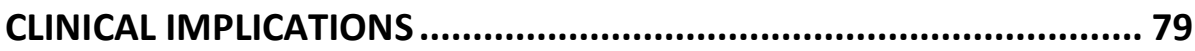

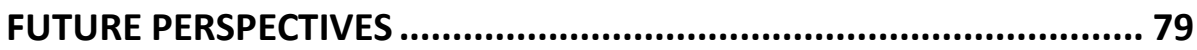

POPULÄRVETENSKAPLIG SAMMANFATTNING ............................... 81

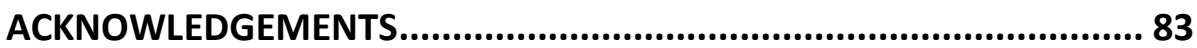

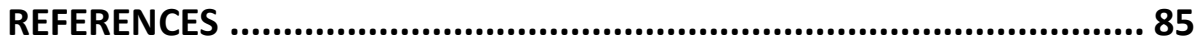

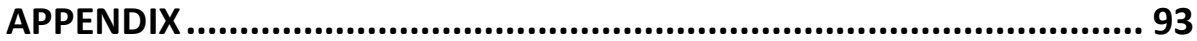

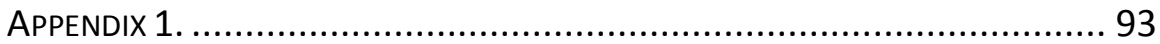

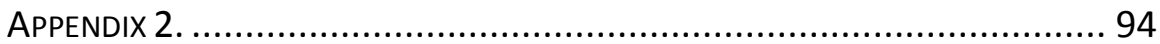

Paper I

Paper II

Paper III

Paper IV 



\section{Introduction}

Surgery is a cornerstone in the treatment of gynecological cancer. In addition to removing the affected gynecological organs, the surgery often includes lymphadenectomy in order to establish a correct staging of the cancer. Correct surgical staging is important for prediction of prognosis and for tailoring the adjuvant treatment.

Endometrial cancer is the most common gynecological cancer in Sweden, with nearly 1,500 women diagnosed annually [Socialstyrelsen 2021]. The Swedish National Guidelines for treatment of endometrial cancer (SNGEC) [SNGEC 2012] have since 2012 recommended a comprehensive lymphadenectomy in conjunction with surgery for endometrial cancer in women who present with apparent early-stage endometrial cancer with unfavorable prognostic factors such as deep myometrial invasion or a histopathology demonstrating low differentiated endometrioid adenocarcinoma or non-endometrioid histology. The guidelines do not consider lymphadenectomy necessary if the histopathology reveals a high or moderately differentiated endometrioid adenocarcinoma without deep myometrial invasion.

Lymphadenectomy is associated with increased intra- and postoperative morbidity. In gynecologic cancer, lymphadenectomy is associated with the development of lymphedema of the lower limbs and impaired health-related quality of life (HRQoL) that may be seen even in early stages of lymphedema. [Finnane et al. 2011, Dunberger et al. 2013, Angioli et al. 2013, Yost et al. 2014, Rowlands, et al. 2014, Biglia et al. 2015, Kim et al. 2015]. Lymphedema is a chronic disease that may progress if untreated, and even causes severe infections that in the worst-case scenario may be fatal [Bonnetblanc et al. 2003, Al-Niaimi et al. 2009]. The reported incidence of lymphedema after treatment of endometrial cancer varies substantially between $0 \%$ and $49 \%$ [Larson et al.1992, Tanaka et al. 2007, Lindqvist et al. 2017] The methods of determining lymphedema are often different in the reports, which use a mixture of subjective and objective measurements. Not infrequently, the determination of lymphedema has been restricted to only include symptomatic patients that seek medical care [Hidaka et al. 2007, Konno et al. 2011, Biglia et al. 2015, Mendivil et al. 2016, Mitra et al.2016]. Consequently, it is difficult to compare the results and draw reliable conclusions. Still, there is no consensus on what method should be considered as the 'gold standard' to define lymphedema and for use in research or in clinical practice [Lindqvist et al. 2017, Russo et al. 2021].

Lymphadenectomy is considered to be a major risk factor for lymphedema after treatment of endometrial cancer. [Yost et al. 2014, Todo et al. 2015, Mitra et al. 2016]; other suggested risk factors are age [Deura et al. 2015, Yoshihara et al. 2020], body mass index (BMI) [Yost et al. 2014, Mendivil et al. 2016], the extent of the lymphadenectomy [Beesley et al. 2015], adjuvant chemotherapy [Pigott et al. 2020] and radiation therapy [Todo et al. 2015]. The reports of risk factors for lymphedema are not consistent, mainly because there are different methods of determining the occurrence of lymphedema. The inconsistency raises concerns about the validity of risk factors and the use of these in clinical practice.

The consequences of lymphadenectomy after surgery for endometrial cancer have therefore not been fully or systematically explored. The true incidence of lymphedema, the real impact on quality of life, and risk factors are not sufficiently established, and thus more research is merited, with well-designed studies. 


\section{Background}

\section{Endometrial cancer}

Endometrial cancer is the most common gynecological cancer in Sweden, with an annual incidence of nearly 26 out of 100000 women (2019). The incidence has increased over time since the early 1970s, but the trend seems to have reversed during the last decade (Figure 1).

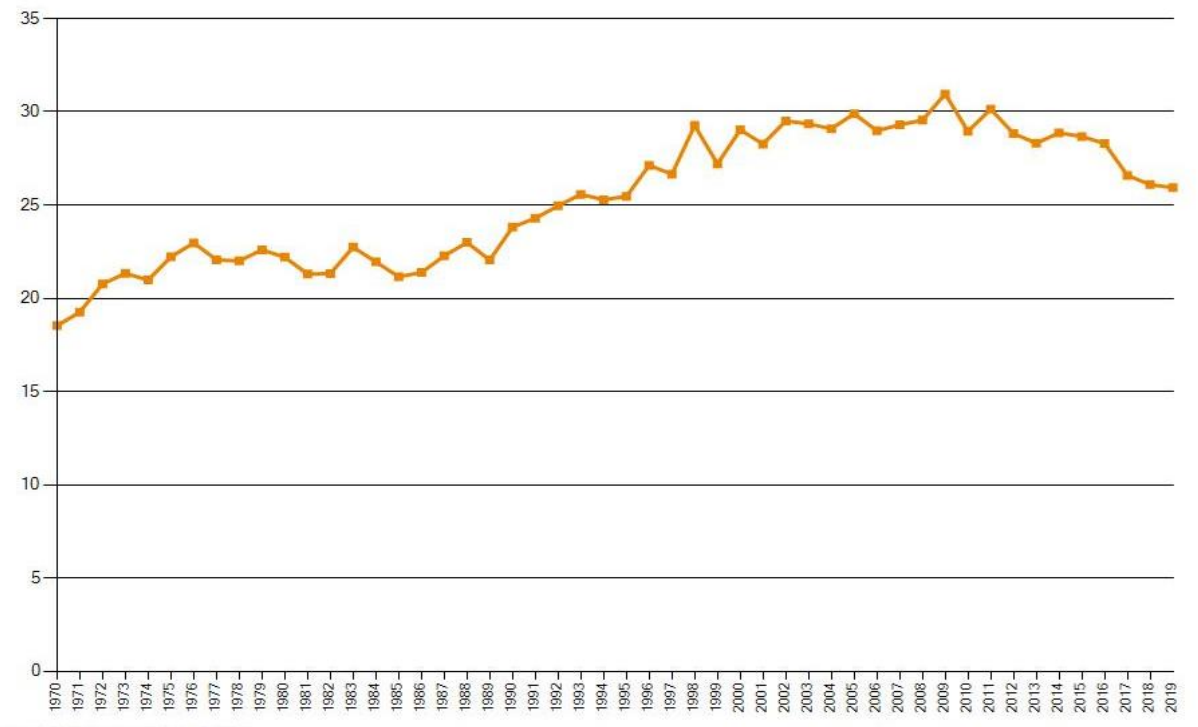

Socialstyrelsens statistikdatabas 2021-0423

Figure 1. Annual incidence of endometrial cancer per 100000 women in Sweden, 1970-2019, all ages. Statistics from Socialstyrelsen [Socialstyrelsen 2021].

\section{Etiology}

Endometrial cancer arises in the endometrium. In 1983, JV Bokhman presented a hypothesis about the etiology of endometrial cancer and postulated two different pathogenetic types of endometrial cancer, type I and type II [Bokhman 1983]. Type 1 endometrial cancers, which constitute the majority, are mainly histologically low-grade endometrioid estrogen- and progesterone receptor-positive. They are associated with high BMI and show good prognosis. In contrast, type II endometrial cancers are histologically high-grade endometrioid or non-endometrioid, demonstrate loss of hormone receptors, and are more aggressive with a worse prognosis. The basic tenets of this classification of endometrial cancer have been confirmed (Suarez et al. 2017). The classification is still used today and constitutes the basis for treatment recommendations of endometrial cancer in the SNGEC [SNGEC 2012].

Rapidly evolving research in the oncogenetics of endometrial cancer within the last decade has demonstrated significant differences in gene expression between type I and type II endometrial cancer [Bansai et al. 2009] (Table 1). The clinical implications of these differences are under evaluation. Although the evaluation has not concluded yet or been implemented in clinical practice, the preliminary results of gene typing seem very promising for tailoring the treatment of endometrial cancer in the future. 
Table 1. Differences in gene expression between type I and type II endometrial cancer [Bansai et al. 2009].

\begin{tabular}{|l|c|c|}
\hline Genetic change & Type l-cancer (\%) & Type II-cancer (\%) \\
\hline PTEN-inactivation & $50-80$ & 10 \\
\hline K-ras-mutation & $15-30$ & $0-5$ \\
\hline B-catenin-mutation & $20-40$ & $0-3$ \\
\hline Microsatellite instability & $20-30$ & $0-5$ \\
\hline p53-mutation & $10-20$ & $80-90$ \\
\hline HER-2/neu-amplification & $10-30$ & $40-80$ \\
\hline p16-mutation & 10 & 40 \\
\hline E-cadherin & $10-20$ & $60-90$ \\
\hline
\end{tabular}

\section{Histology}

The majority of endometrial cancers are endometrioid adenocarcinoma (75-80\%). According to the International Federation of Obstetrics and Gynecology (FIGO) classification, the endometrioid adenocarcinomas are assigned a FIGO grade, 1 to 3, based on the degree of glandular differentiation of the endometrium. Grade 1 tumors exhibit $\leq 5 \%$ solid non-glandular, non-squamous growth; Grade 2 tumors from $6 \%$ to $50 \%$; and Grade 3 tumors $>50 \%$. Nearly $43 \%$ of the endometrioid ECs are classified as FIGO Grade 1, 38\% as FIGO Grade 2, and 17\% as FIGO Grade 3. Serous carcinoma makes up 5-10\%, clear-cell adenocarcinoma 1-2\% and other types $<10 \%$ (mixed adenocarcinoma, carcinosarcoma, neuroendocrine carcinoma and undifferentiated carcinoma) [SNGEC 2012, Murali et al. 2014].

\section{Epidemiology}

Obesity is the strongest risk factor for type I endometrial cancer and is associated with $40 \%$ of all cases of endometrial cancer in Western Europe [Bergstrom et al. 2001]. A BMI > 25 is associated with a double risk and BMI >30 with a triple risk [Calle et al. 2003]. In premenopausal women, the increased risk is mainly due to increased insulin resistance [Yang et al. 2019], ovarian estrogen excess, anovulation and chronic progesterone deficiency. In postmenopausal women, androgens are converted to estrogen by aromatase in the fat tissue, which stimulates endometrial cell growth and promotes angiogenesis.

Other risk factors for developing endometrial cancer are nulliparity, early menarche and late onset menopause, and use of tamoxifen. Tamoxifen acts as an anti-estrogen in breast tissue, but acts like an estrogen in the uterus and stimulates the endometrium, which increases the risk of endometrial cancer [American Cancer Society 2021].

Hormonal contraceptives, parity [Henderson et al. 1983], smoking and physical activity and exposure to sunlight [Epstein et al. 2009] are protective against developing endometrial cancer.

\section{Staging}

The purpose of a staging system is to offer a classification of the extent of the cancer in order to provide a method of conveying one's clinical experience to others for the comparison of treatment methods without ambiguity. The FIGO was the first organization to develop a staging 
system for gynecologic cancer and presented the first staging classification in 1958 [Odicino et al. 2008]. In 2009, the most recent edition of the FIGO staging of endometrial cancer was published (Table 2) [Pecorelli et al. 2009]. The current FIGO staging of endometrial cancer is based on surgical findings.

Table 2. Staging of endometrial cancer according to the FIGO classification from 2009 [Pecorelli et al. 2009].

\begin{tabular}{c|l}
\hline FIGO stage & $\begin{array}{l}\text { Description of spread } \\
\text { Stage I }\end{array}$ \\
\hline Stage IA & \begin{tabular}{l} 
The cancer is found only in the uterus, and it has not spread to other \\
The cancer is found only in the endometrium or less than one-half of \\
the myometrium. \\
The tumor has spread to one-half or more of the myometrium. \\
The tumor has spread from the uterus to the cervical stroma but not \\
to other parts of the body. \\
The cancer has spread beyond the uterus, but it is still only in the \\
pelvic area. \\
The cancer has spread to the serosa of the uterus and/or the tissue \\
of the fallopian tubes and ovaries but not to other parts of the body. \\
The tumor has spread to the vagina or next to the uterus. \\
\hline Stage III
\end{tabular}$\quad \begin{array}{l}\text { The cancer has spread to the regional pelvic lymph nodes. } \\
\text { The cancer has spread to the para aortic lymph nodes with or without } \\
\text { spread to the regional pelvic lymph nodes. } \\
\text { The cancer has metastasized to the rectum, bladder, and/or distant } \\
\text { organs. }\end{array}$ \\
\hline Stage IIIB & $\begin{array}{l}\text { The cancer has spread to the mucosa of the rectum or bladder. } \\
\text { The cancer has spread to lymph nodes in the groin area, and/or it } \\
\text { has spread to distant organs, such as the bones or lungs. }\end{array}$ \\
\hline Stage IIIC2 &
\end{tabular}

\section{Pre-treatment evaluation}

After the diagnosis of endometrial cancer has been confirmed histopathologically, different imaging diagnostic methods are used to evaluate the occurrence of dissemination of the cancer. Myometrial invasion, which is an independent risk factor for worse prognosis, is evaluated by transvaginal sonography (TVS) or magnetic resonance imaging (MRI), and distant spread is evaluated by computed tomography (CT) or MRI. The findings in these investigations are important for the determination of the primary treatment.

\section{Treatment}

In the SNGEC, patients are preoperatively categorized as having low-risk or high-risk endometrial cancer based on the histological classification (endometrioid, non-endometrioid), FIGO grade (1-3), together with the preoperative imaging diagnostic evaluation (TVS, CT or MRI).

A patient with an endometrioid adenocarcinoma, FIGO Grade 1-2, myometrial invasion $<50 \%$, and no signs of distant spread is classified as having low-risk endometrial cancer. If non-endometrial histology or endometrioid adenocarcinoma FIGO Grade 3, or cervical involvement, or endometrioid adenocarcinoma FIGO Grade 1-2 with myometrial invasion $>50 \%$ were found the patient is classified as having a high-risk endometrial cancer. 
The primary treatment for endometrial cancer, according to the SNGEC edition from 2012, is surgery comprising peritoneal washing, total hysterectomy (TH) and bilateral salpingo-oophorectomy (BSOE) for low-risk endometrial cancer. For high-risk endometrial cancer, in addition to the $\mathrm{TH}$ and BSOE, a comprehensive lymphadenectomy in the pelvis and para-aortical is recommended, (Table 3). An overview of the lymphadenectomy in surgery for endometrial cancer is presented in Figure 2.

Table 3. Overview over algorithm for treatment of low- and high-risk endometrial cancer.

\begin{tabular}{|c|c|c|}
\hline & Low-risk EC & High-risk EC \\
\hline Histology & $\begin{array}{l}\text { Endometrioid, FIGO } \\
\text { Grade 1-2 }\end{array}$ & $\begin{array}{l}\text { Endometrioid FIGO Grade } 3 \\
\text { Serous adenocarcinoma } \\
\text { Clear-cells adenocarcinoma } \\
\text { Undifferentiated, mixed carcinoma, carci- } \\
\text { nosarcoma, neuroendocrine tumor }\end{array}$ \\
\hline $\begin{array}{l}\text { Myometrial inva- } \\
\text { sion }\end{array}$ & $<50 \%$ & $\geq 50 \%$ \\
\hline Cervical invasion & No & Yes \\
\hline Surgical regimen & $\begin{array}{l}\text { Peritoneal washing } \\
\text { TH, BSOE }\end{array}$ & $\begin{array}{l}\text { Peritoneal washing } \\
\text { TH, BSOE, pelvic and para aortal lym- } \\
\text { phadenectomy } \\
\text { Omentectomy (in non-endometrioid his- } \\
\text { tology) }\end{array}$ \\
\hline
\end{tabular}

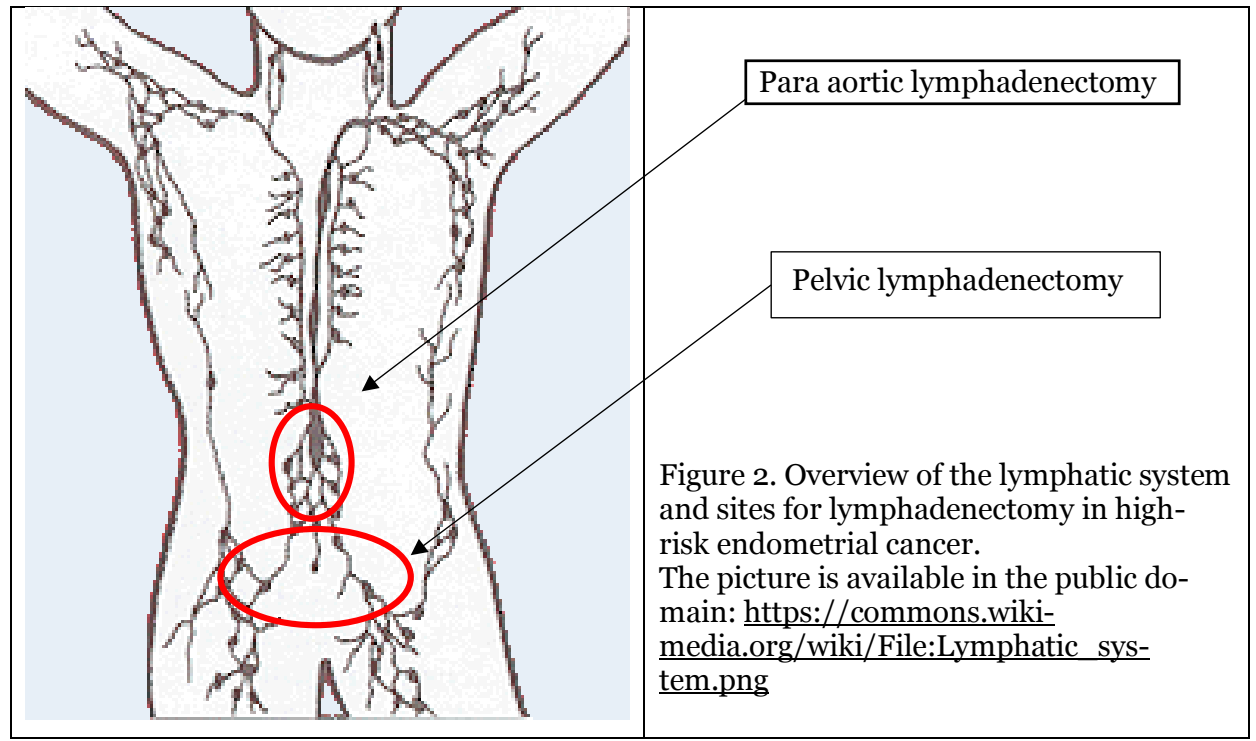




\section{Prognosis}

The overall 10-year survival for all patients with endometrial cancer in Sweden between 2010 -2020 is shown in Figure 3. There is a substantial difference in survival between the histological subtype, and surgical FIGO stage. Early-stage (FIGO surgical stage I-II) low-risk endometrial cancer has a good prognosis and high expectancy for long-term survival whereas higher FIGO stages have a poorer prognosis.

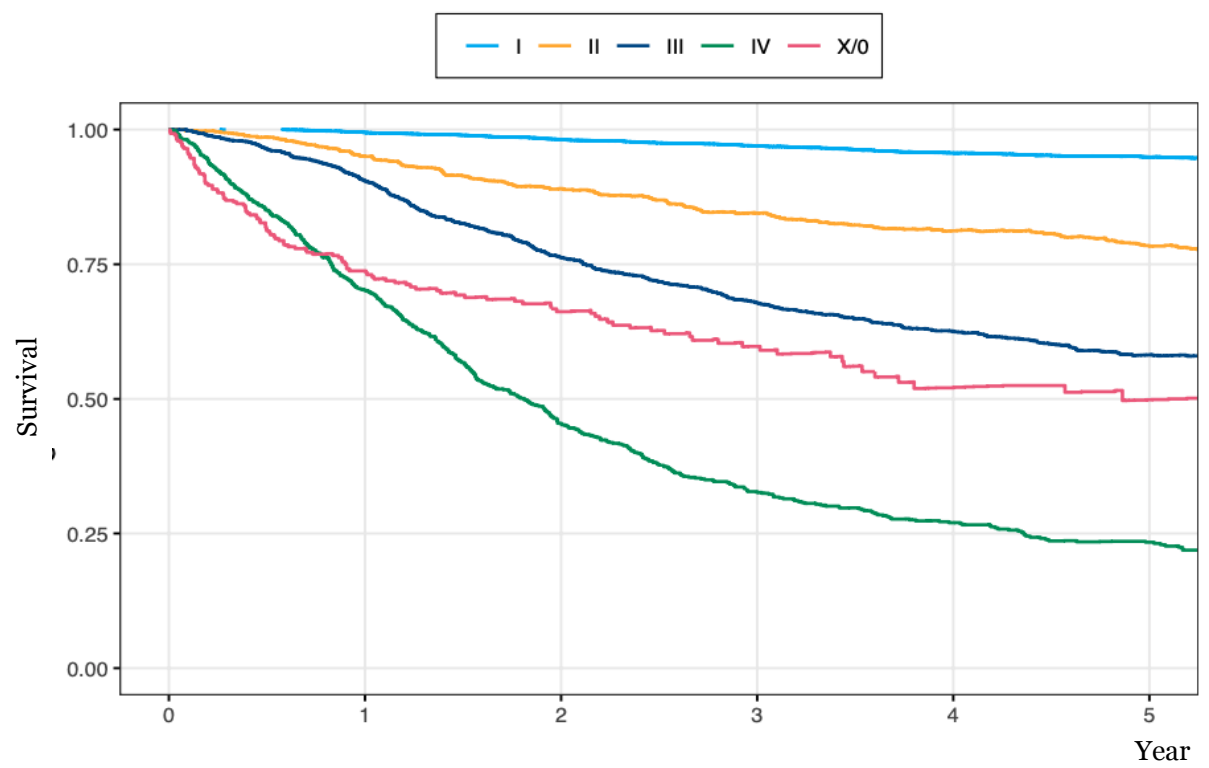

Figure 3. The overall 10-year survival for all patients with endometrial cancer in Sweden in years between $2010-2020$ in relation to FIGO stage (stage I - IV). X/0= stage unknown. (https://cancercentrum.se/samverkan. Personal communication)

\section{The lymphatic system}

The lymphatic system has many functions. Besides being a part of the immune system, protecting the body from foreign agents, it is involved in body fluid regulation [Choi et al. 2012], the absorption and transport of digestive tract fats [Hussain 2000], and in removing cellular waste [Welter et al. 2013].

\section{Lymphatic anatomy}

In 1921, the two German gynecologists Albert Döderlein and Bernhard Krönig described the female genital lymphatic drainage system in their textbook of gynecological operations (Figure 4). Döderlein and Krönig described three lymphatic pathways; 1: from the vulva to the lower third of the vagina, which drained into the inguinofemoral nodes, 2: from the upper vagina to the cervix uteri, which drained to the pelvic wall vessels, and 3: from the uterus and the ovaries along the ovarian vessels to the para aortic and para caval basins between the renal vessels and the inferior mesenteric artery [Döderlein et al. 1921]. 


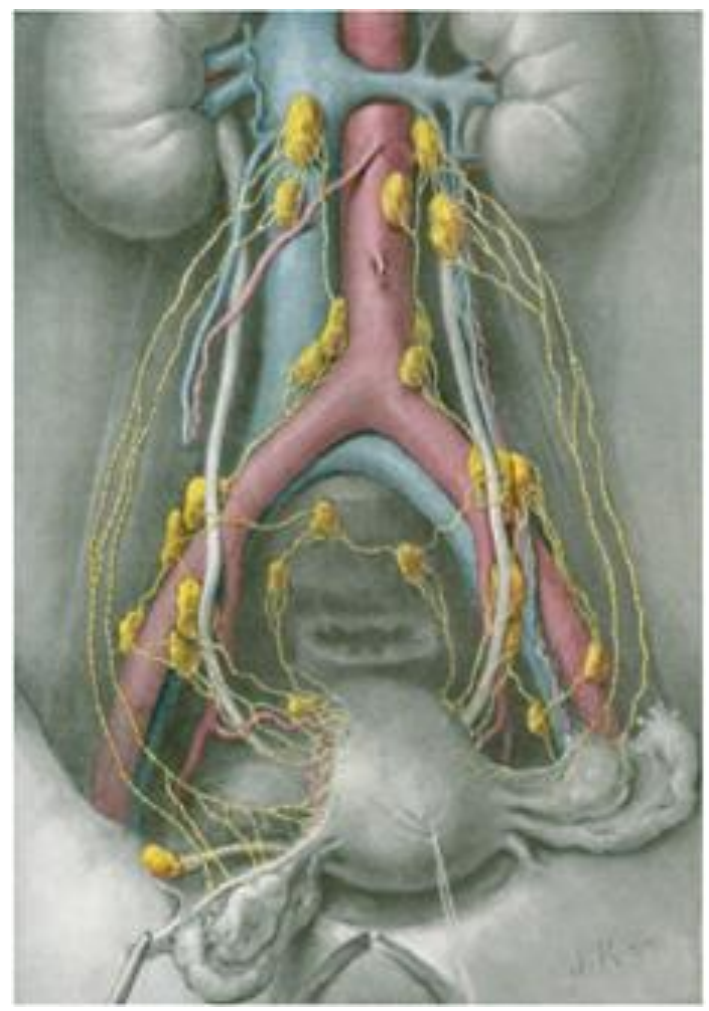

Figure 4. Original description of the lymphatic system in the pelvic region by Döderlein and Krönig 1921. Reprinted with kind permission from Georg Thieme Verlag Stuttgart.

Recently, Barbara Geppert et al. confirmed the three lymphatic pathways in systematic studies using robotic surgery and the fluorescence technique, but also found that the second lymphatic pathway (described by Döderlein) could alter course and go directly from the uterus, passing the bifurcation of the communis vessels, instead of passing the iliac vessels, named the lower paracervical pathway (Figure 5) [Geppert 2018]. 


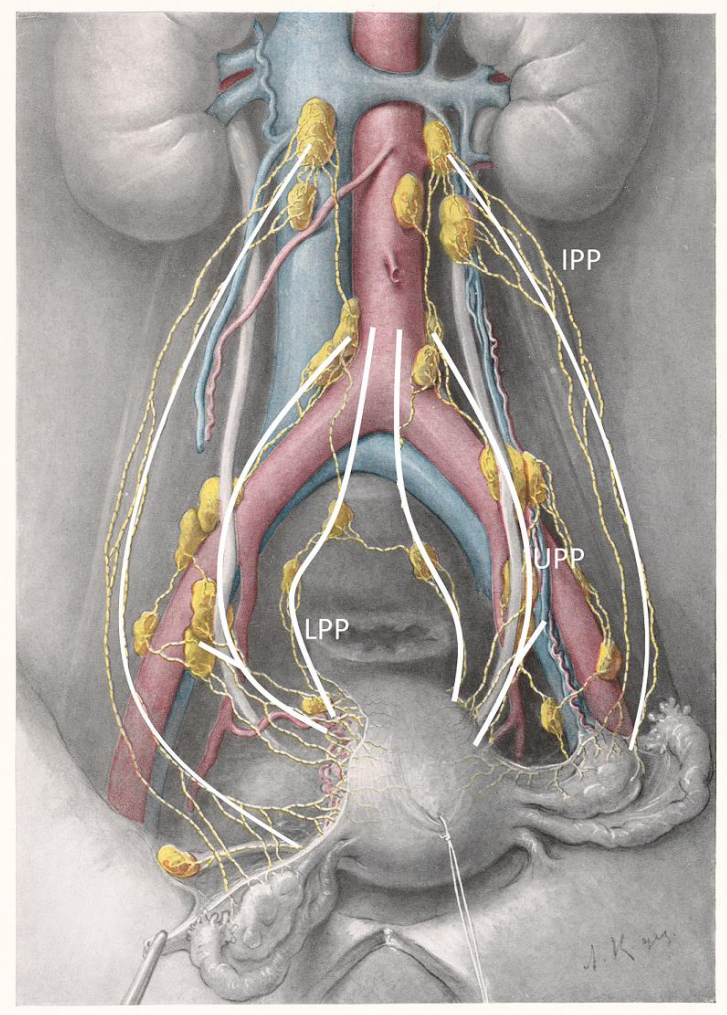

Figure 5. Schematic overview of the uterine lymphatic pathways, described by Gebbert. Upp= upper paracervical pathway, LPP= lower paracervical pathway, IPP=infundibulopelvic pathway. Reprinted with kind permission from B. Geppert [Geppert 2018].

\section{Lymphedema}

Lymphedema is a chronic disease of the lymphatic system characterized by an increased collection of lymphatic fluid in the body, causing swelling which can led to skin and tissue changes. [Executive Committee of the International Society of Lymphology 2020, Sleigh et al. 2021]. Lymphedema can only be diagnosed when edema can be demonstrated to be caused by an abnormality involving the lymphatic system, "edema of lymphatic origin" [Bourgeois et al. 2015]. Lymphedema is divided into primary and secondary lymphedema. Primary lymphedema is an inherited or congenital condition whereas secondary lymphedema is associated with an injury or obstruction to the lymphatic system that is an acquired condition, such as after cancer treatment. In the Western world, primary lymphedema is rare; in the US, less than 1 in 100,000 is affected. In contrast, secondary lymphedema is much more common and affects 1 in 1,000 Americans [Sleigh et al. 2021].

The prevalence of lymphedema, independent of etiology and gender, was investigated by Mofatt et al. in the United Kingdom. The overall prevalence was 1.33/1000 but the prevalence 
was 4.6 times higher in women than in men $(2.15 / 1000$ vs $0.47 / 1000$ in men) [Mofatt et al. 2003].

\section{Lymphedema in a historic perspective}

Lymphedema was described by the ancient Egyptians in 2000 BC (Before Christ). The lymphedema at that time was most probably caused by a lymphatic filariasis, a parasitic disease caused by microscopic, thread-like worms. There are several ancient statues of Pharaoh Mentuhotep II (reigned 2060-2009 BC) that show him with a swollen left limb, elephantiasis, (Figure 7) [Mendoza et al. 2009]. Also Princess Ati of Egypt (1516-1481 BC) was sculptured with oversize arms and legs, presumably lymphedema (Figure 8).

The exploration of the lymphatic system has a documented history dating back before Christ, and the most famous name among the researchers is Claudius Galenus, a Greek physician and philosopher most often referred to as 'Galen`. Galen is considered to be one of the fathers of anatomy and pathology, and part of his legacy was the description of the blood circulation, and from a lymphatic perspective "vessels containing a milky fluid".

Galen influenced medical science for more than 1300 years. After 1500 AD (Anno Domini, After Christ), the lymphatic anatomical landmarks, the thoracic duct and the cloacal bursa, were identified, respectively, by Bartolomeo Eustachi in 1500 [Adanir et al. 2021] and by Gabriele Falloppio in 1621. The latter is also known as the father of embryology.

Another milestone in the lymphatic history came in 1651 when Jean Perquet described the thoracic duct and the valves in the lymph vessel, and also the reservoir of the chyle, the cisterna chyli. Importantly, he also described the milky-like lymph lacteals that ran to the reservoir of the chyle and to the thoracic duct.

The Danish physician Thomas Bartholin, professor at the University of Copenhagen, first described the small lymphatic vessels outside the gut and the liver in 1652. Simultaneously, the Swedish physician and professor at Uppsala University, Olof Rudbeck, presented similar findings, but due to internal disputes, Rudbeck's results were first published in 1653.

The first to provide a graphic presentation of the lymphatic system was the Italian anatomist and surgeon, Giovanni Guglielmo (1627-1677). The lymphatics anatomy continued to be explored, but it was not until the twentieth century that the function of the lymphatics and their pathology were revealed [Natale et al. 2017]. 


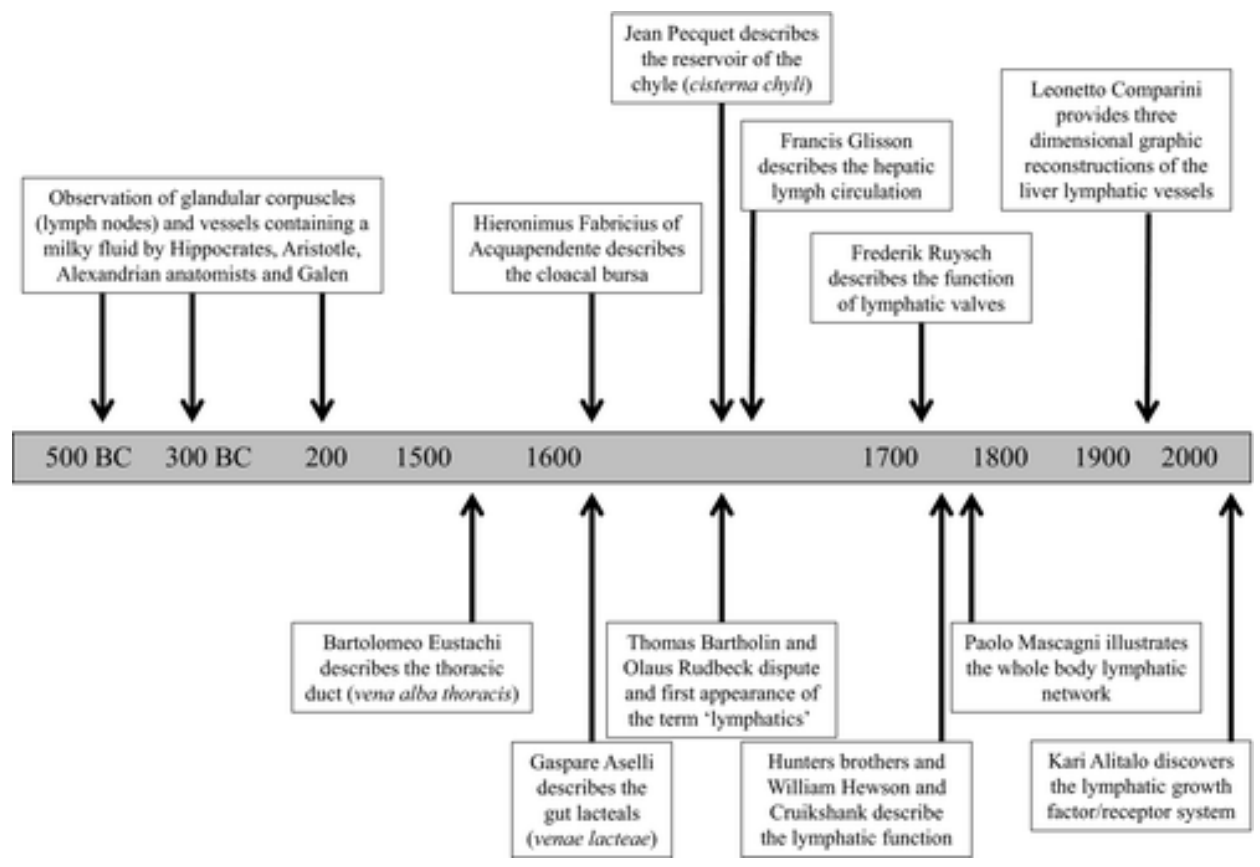

Figure 6. "The history of the lymphatic system" [Natale et al. 2017]. Reprinted with permission from the publisher John Wiley and Sons by the license nr 5157010873968.

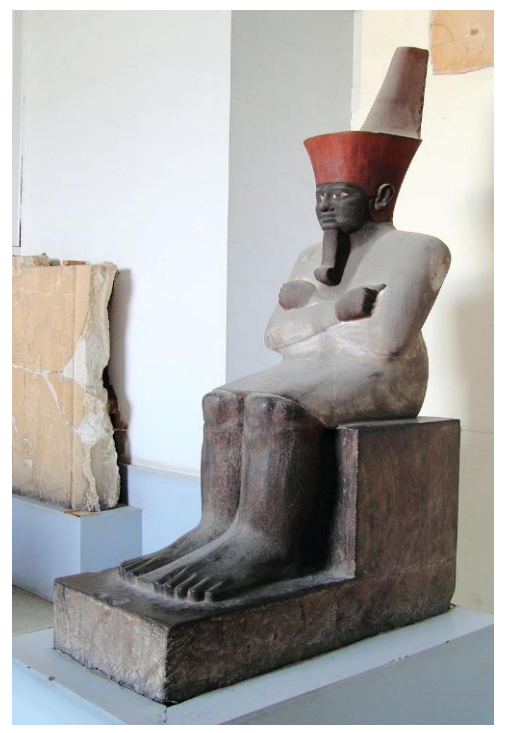

Figure 7. Ancient Egyptian statue of Pharaoh Mentuhotep II. Egyptian Museum, Cairo. Wikimedia Commons; reprinted by the license CC BY-SA 


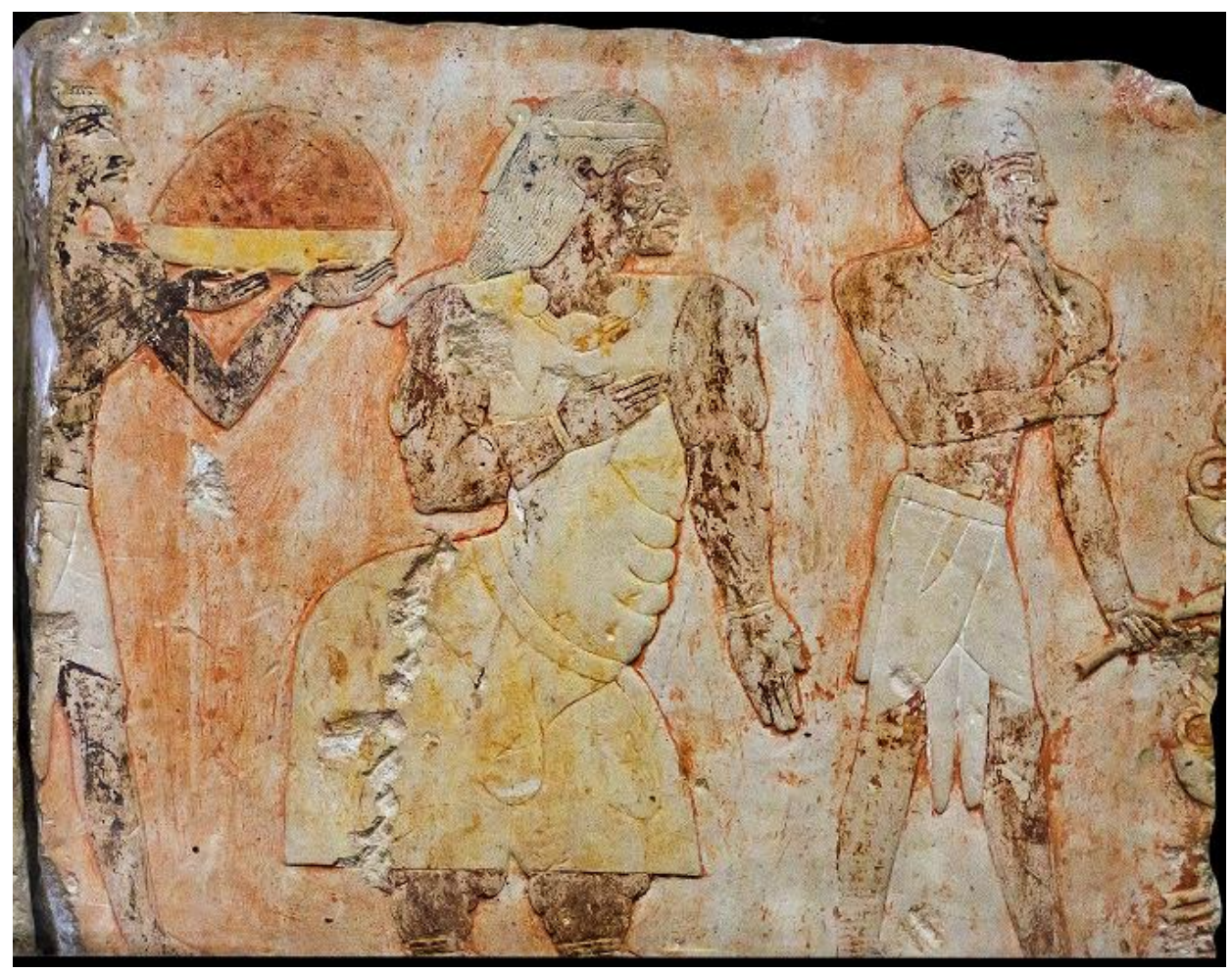

Figure 8. Princess Ati of Egypt (Osiritkos at Wikimedia Commons 2021). Reprinted by the license CC-BY-SA.

\section{Pathophysiology of lymphedema}

The most common reasons for lymphedema in developed countries are secondary lymphedema, secondary to cancer treatment, mainly caused by disruption of the lymphatic system by lymphadenectomy or radiation therapy. When disruption of the lymphatic system occurs, independent of reason, the transport of fluid becomes insufficient and is disturbed. The normal physiological transport of lymphatics is blocked (stage 0). The excess fluid in the extracellular space creates swelling (stage I) and the stasis of protein rich intracellular fluid and cellular debris causes chronic inflammation (stage II). This process initiates the proliferation of stromal tissue which is followed by increased adipose deposition and tissue fibrosis (stage III). [Executive Committee of the International Society of Lymphology 2020]. The pathways of the pathophysiological process are illustrated in Figure 9. 


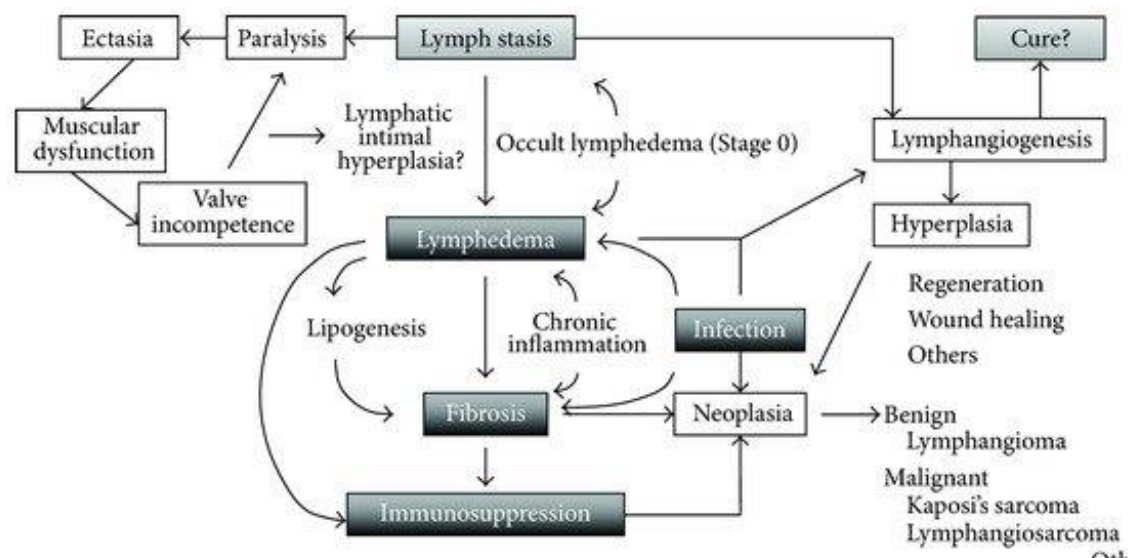

Others

Figure 9. Schematic diagram of the pathophysiology of lymphedema. [Saito Y et al. 2013].

The lymphatic system plays an important role in the immune response. Injury to the lymphatic systems results in a chronic inflammatory state distal to the zone of injury that promotes an upregulation of endogeneous danger signal molecules. These molecules alarm and activate the innate immune system [Saito et al. 2013]. The cascade activation of the immune system in turn leads to a sophisticated regulation of inflammatory lymphangiogenesis and chronic inflammatory reactions via various immune cells, cytokines, and growth factors.

A suggested model of the influence of injury of the lymph systems on the pathophysiology of lymphedema is presented in Figure 10, and the role of immunological cells and mediators in lymphedema development is shown in Table 4.

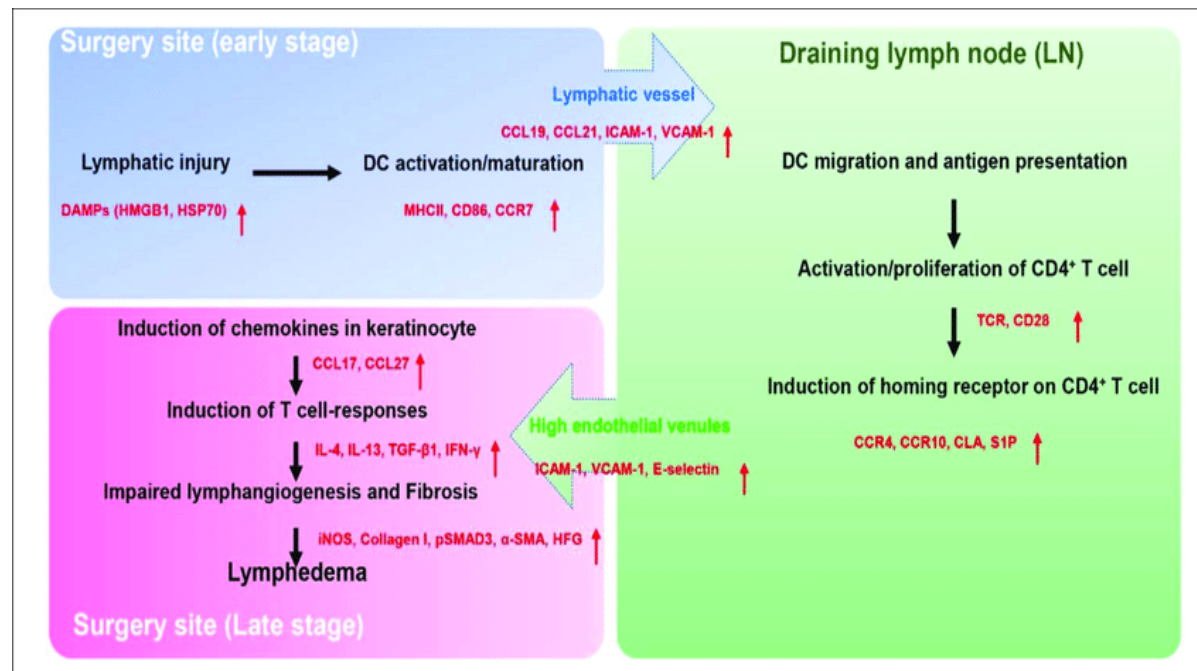

Figure 10. The proposed pathophysiology of secondary lymphedema. [Kataru et al. 2019]. 


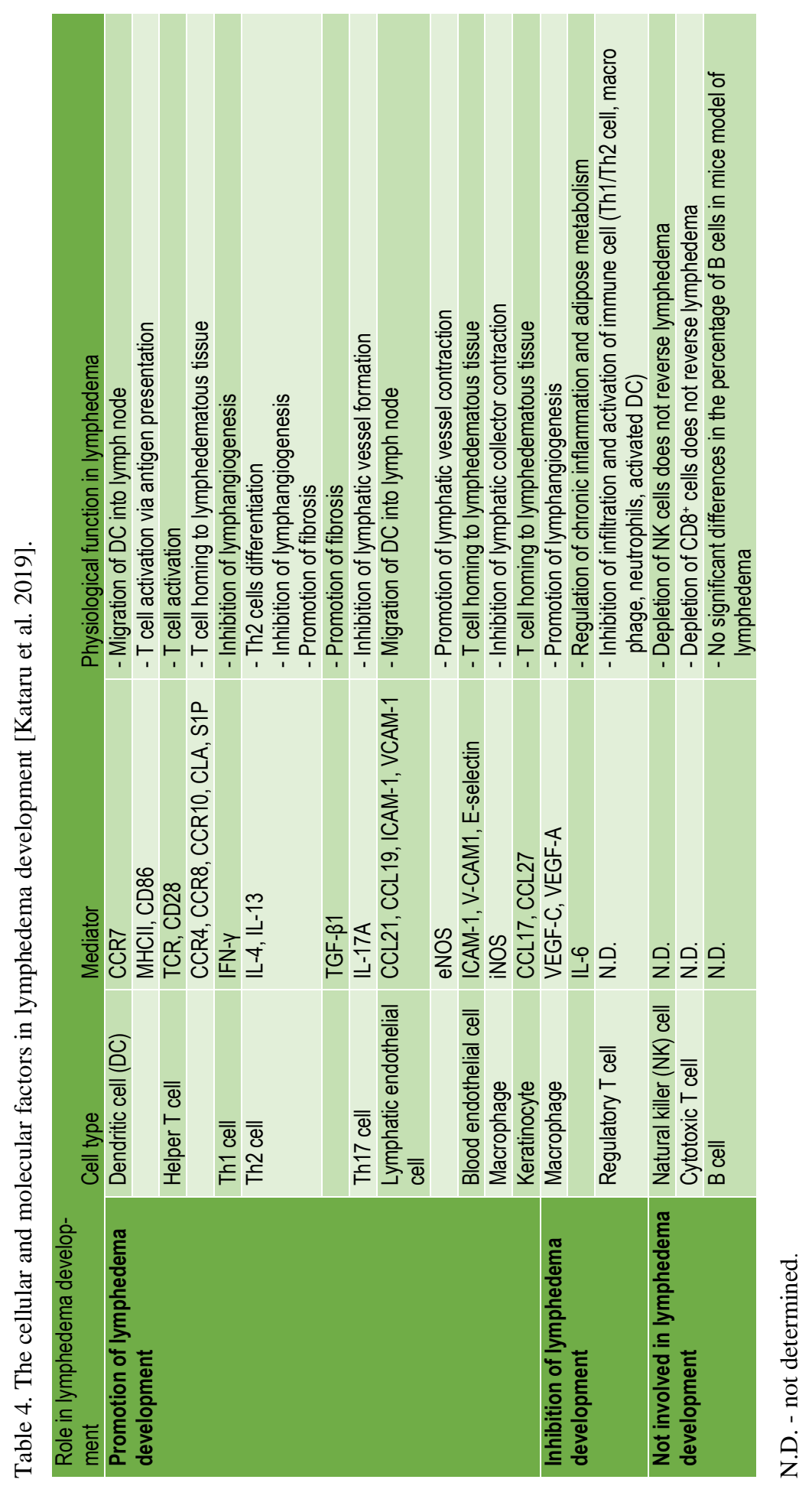




\section{Risk factors for lymphedema}

There are several suggested risk factors for lymphedema after surgery of endometrial cancer in the literature, such as lymphadenectomy [Yost et al. 2014, Todo et al. 2015, Mitra et al. 2016], the extent of LA [Beesley et al. 2015], age [Deura et al. 2015, Yoshihara,et al. 2020], BMI [Yost et al. 2014, Mendivil et al. 2016], radiation therapy [Todo et al. 2015], and chemotherapy [Pigott et al. 2020]. However, the suggested risk factors present a wide discrepancy, mainly because different definitions and methods are used to determine lymphedema [Lindqvist et al. 2017].

Several researchers have emphasized the need for a gold standard method for defining and determining lymphedema, which would contribute to the identification of true risk factors for lymphedema [Biglia et al. 2017, Lindqvist et al. 2017, Dessources et al. 2020].

\section{Diagnostics of lymphedema}

Several methods have been described to diagnose and grade lymphedema. Only a few studies have made a comprehensive evaluation of the methods. In a systematic review of the measurement properties of clinical instruments for measurement of lymphedema, Hidding et al. highlighted the limitations associated with research of lymphedema: lack of a uniform definition of lymphedema and a gold standard as a reference test, and bias attributed to study design, patient selection, description of lymphedema, blinding of test outcomes, and the number of included participants [Hidding et al. 2016]. Today, there is still no consensus on a gold standard for diagnosing or grading lymphedema [Lindqvist, et al. 2017, Biglia et al. 2017, Executive Committee of the International Society of Lymphology 2020, Russo et al. 2021].

The diagnostic methods can be divided into objective and subjective methods. In addition, the objective methods can be further subdivided into non-invasive and invasive methods. An overview of the methods most commonly used in the literature is presented in Table 5.

Table 5. Overview of diagnostic tools for measuring lymphedema

\begin{tabular}{|c|c|c|c|}
\hline Method & Name & Abbreviation/or description & References \\
\hline \multicolumn{4}{|l|}{ Objective methods } \\
\hline \multicolumn{4}{|l|}{ Non-invasive } \\
\hline \multirow[t]{6}{*}{ Clinical grading } & $\begin{array}{l}\text { International Society of } \\
\text { Lymphology }\end{array}$ & ISL & $\begin{array}{l}\text { Executive Committee of the } \\
\text { International Society of } \\
\text { Lymphology } 2020 \text {. }\end{array}$ \\
\hline & Bruna' clinical grading & & Bruna J et al. 1999 \\
\hline & Stemmer' sign & & Stemmer R 1976 \\
\hline & $\begin{array}{l}\text { American Physical Ther- } \\
\text { apy Association } \\
\text { lymphedema rating sys- } \\
\text { tem }\end{array}$ & APTA & $\begin{array}{l}\text { American Physical Therapy } \\
\text { Association } 2001\end{array}$ \\
\hline & $\begin{array}{l}\text { Late Effects of Normal } \\
\text { Tissue/Subjective, Objec- } \\
\text { tive, Management, Ana- } \\
\text { lytic components three- } \\
\text { item system }\end{array}$ & LENT/SOMA & Pavy et al. 1995 \\
\hline & $\begin{array}{l}\text { National Cancer Institute } \\
\text { - Common Toxicity Crite- } \\
\text { ria }\end{array}$ & $\mathrm{NCl}-\mathrm{CTC}$ & Cheville et al. 2003 \\
\hline \multirow[t]{2}{*}{$\begin{array}{l}\text { Volume measure- } \\
\text { ment }\end{array}$} & $\begin{array}{l}\text { Circumferential measure- } \\
\text { ments }\end{array}$ & $\begin{array}{l}\text { Systematic circumferential measurements ena- } \\
\text { ble calculation of volume by the cone model }\end{array}$ & $\begin{array}{l}\text { Sitzia J et al. } 1995 . \\
\text { Taylor R et al. } 2006 .\end{array}$ \\
\hline & Perometry & $\begin{array}{l}\text { Uses infrared light to scan a limb and obtain } \\
\text { measurements of the limb's circumference. }\end{array}$ & Stanton et al. 1997 \\
\hline
\end{tabular}




\begin{tabular}{|c|c|c|c|}
\hline & Plethysmography & $\begin{array}{l}\text { The limb is immersed in a water bath, drained } \\
\text { water is measured. }\end{array}$ & Swedborg 1977 \\
\hline \multirow[t]{2}{*}{$\begin{array}{l}\text { Bioelectrical prop- } \\
\text { erties }\end{array}$} & $\begin{array}{l}\text { Bioelectric impedance } \\
\text { analysis }\end{array}$ & $\mathrm{BIA}$ & Cornish 2006 \\
\hline & $\begin{array}{l}\text { Bioelectric impedance } \\
\text { spectroscopy }\end{array}$ & BIS & $\begin{array}{l}\text { Ward et al. } 2011 \\
\text { Ridner et al. } 2014\end{array}$ \\
\hline \multirow[t]{3}{*}{$\begin{array}{l}\text { Non-invasive diag-- } \\
\text { nostic imaging }\end{array}$} & Computed tomography & CT. & Goyal et al. 2015 . \\
\hline & $\begin{array}{l}\text { Magnetic resonance im- } \\
\text { aging }\end{array}$ & MRI & $\begin{array}{l}\text { Haaverstad et al. } 1994 \\
\text { Liu et al. } 1998\end{array}$ \\
\hline & Ultrasonography & Mainly differential diagnostics. & Goyal et al. 2015 \\
\hline \multicolumn{4}{|l|}{$\begin{array}{l}\text { Invasive diagnostic } \\
\text { imaging }\end{array}$} \\
\hline & Lymphography & $\begin{array}{l}\text { Lymphography opacifies the lymphatic chan- } \\
\text { nels. }\end{array}$ & Guermazi et al. 2003 \\
\hline & Lymphoscintigraphy & $\begin{array}{l}\text { Demonstrates the functional abnormality in the } \\
\text { lymphatic pathway through injection of a radio- } \\
\text { active tracer. }\end{array}$ & Bourgeois 2015 \\
\hline & $\begin{array}{l}\text { Near-infrared fluores- } \\
\text { cence imaging }\end{array}$ & $\begin{array}{l}\text { A fluorescent substance is used for imaging the } \\
\text { lymphatic structures. }\end{array}$ & Bourgeois 2015 \\
\hline & $\begin{array}{l}\text { MRI with intradermal con- } \\
\text { trast }\end{array}$ & $\begin{array}{l}\text { Evaluating anatomical and functional status of } \\
\text { lymphatic vessels and lymph nodes. }\end{array}$ & Goyal et al. 2015 \\
\hline & $\begin{array}{l}\text { Fluorescence micro-lym- } \\
\text { phangiography }\end{array}$ & & Bollinger et al. 1981 \\
\hline \multicolumn{4}{|l|}{ Subjective methods } \\
\hline \multirow[t]{9}{*}{$\begin{array}{l}\text { Lymphedema-spe- } \\
\text { cific HRQoL ques- } \\
\text { tionnaires }\end{array}$} & $\begin{array}{l}\text { Quality of life assessment } \\
\text { tool for lymphedema of } \\
\text { the limbs }\end{array}$ & $\begin{array}{l}\text { LYMQOL } \\
\text { Swedish version of LYMQOL }\end{array}$ & $\begin{array}{l}\text { Keeley et al. } 2010 \\
\text { Wedin et al. } 2020\end{array}$ \\
\hline & $\begin{array}{l}\text { Swedish Lymphedema } \\
\text { Quality of Life Inventory }\end{array}$ & SLQOLI & Klernäs et al. 2010 \\
\hline & $\begin{array}{l}\text { Lymphedema Quality of } \\
\text { Life Inventory }\end{array}$ & LyQOLI & Klernäs et al. 2015 \\
\hline & $\begin{array}{l}\text { European Organization } \\
\text { for Research and Treat- } \\
\text { ment of Cancer Quality of } \\
\text { Life Questionnaire }\end{array}$ & $\begin{array}{l}\text { EORTC: } \\
\text { Cancer patients:-QLQ-C30 } \\
\text { Endometrial Cancer Module:-QLQ-EN24 } \\
\text { Sexual health:-QLQ-SHO-22 } \\
\text { Symptom-based: -SBQ }\end{array}$ & $\begin{array}{l}\text { European Organization for } \\
\text { research and treatment of } \\
\text { Cancer Quality of life Ques- } \\
\text { tionnaire } 2021\end{array}$ \\
\hline & $\begin{array}{l}\text { Gynecologic Cancer } \\
\text { Lymphedema Question- } \\
\text { naire }\end{array}$ & GCLQ & Carter et al. 2010 \\
\hline & $\begin{array}{l}\text { Functional Assessment of } \\
\text { Cancer Therapy - Endo- } \\
\text { metrial Cancer Subscale }\end{array}$ & FACT-EN & Bonomi et al. 1996 \\
\hline & $\begin{array}{l}\text { Cancer-survivors' unmet } \\
\text { needs measure }\end{array}$ & CaSUN & Hodgkinson et al. 2007 \\
\hline & $\begin{array}{l}\text { Self-Report Lower-Ex- } \\
\text { tremity Lymphedema } \\
\text { Screening Questionnaire } \\
\text { in Women }\end{array}$ & & Yost et al. 2013 \\
\hline & $\begin{array}{l}\text { Freiburger Questionnaire } \\
\text { on Quality of Life }\end{array}$ & FLQA-I & Augustin et al. 2005 \\
\hline
\end{tabular}




\section{Lymphocysts and lymphatic ascites}

Lymphocysts are a complication of lymphadenectomy and consist of accumulated lymphatic tissue in the retroperitoneal space. If the accumulation occurs intra-abdominally it is described as lymphatic ascites [Ghezzi et al. 2012]. The incidence of lymphocysts after surgery for endometrial cancer is sparsely described in the literature. Salehi et al. investigated in a randomized controlled trial with CT verified intra-abdominal lymphocysts and lymphatic ascites one year after surgery an incidence lymphocysts of $21 \%$ and $14 \%$ with ascites. In their study, lymphocysts seemed not to be a clinical problem whereas lymphatic ascites were drained in one patient on several occasions, [Salehi et al. 2019]. In a prospective study after surgery of gynecological cancer, Zikan et al. found an incidence of lymphocysts of $20.2 \%$, of which $5.5 \%$ were symptomatically characterized by pain, hydronephrosis, urinary urgency, venous thrombosis, sepsis, or acute lymphedema. [Zikan et al. 2015].

\section{Quality of Life}

Quality of life was already described by the Greek philosopher Aristotle (384-322 BC) in Nichomachean Ethics, in which he developed the theory of good life, also known as eudaimonia for humans. Eudaimonia may probably best be translated as flourishing or living well and doing well. When he addressed the good life as the happy life, he did not mean that the good life was simply one of feeling happy or amused. Rather, the good life for a person was the active life of functioning well in those ways that were essential and unique to humans. Aristotle clarified that quality of life (QoL) meant different things to different people. He also recognized that it varied according to a person's current situation [Fayers et al. 2000].

In 1948, the World Health Organization (WHO) declared health to be a "state of complete physical, mental and social well-being, and not merely the absence of disease" [World Health Organization 2006], highlighting, for the first time, the importance of three dimensions, i.e. physical, mental and social aspects of health.

Quality of life has a wide meaning and means different things to different people. Therefore, in a scientific context the term 'health-related quality of life' (HRQoL) is used to remove ambiguity. It is generally agreed that it includes general health, physical functioning, physical symptoms and toxicity, emotional functioning, cognitive functioning, role functioning, social wellbeing and functioning, sexual functioning and existential issues [Fayers et al. 2000].

In 1997, Sitzia and Sobrido stated the importance of evaluating the impact of lymphedema on HRQoL as a primary outcome in cancer research [Sitzia et al. 1997].

Several inventories for evaluating the impact of lymphedema on HRQoL have been published (Table 5). These subjective measures are mostly disease-specific but some are mixed with items derived from generic HRQoL forms.

Each of the methods for measuring lymphedema, objectively or subjectively, presents strengths and limitations. Some of the methods are invasive and need special and/or expensive equipment, and thus make the method more risky and less attractive or available in clinical practice. Moreover, it is difficult to compare results if measurements are based on different methods. While circumferential measurement seems to be the most common clinical assessment method to determine lymphedema [Smoot et al. 2011, Brorson et al. 2015], the LYMQOL has recently 
been recommended for evaluating the HRQoL of people with lymphedema [Paramanandam et al. 2021].

\section{Health economics and cost analysis}

Health economic evaluation is important in the decision-making context to identify and introduce new and valid treatment procedures into the health care system.

There are several types of health economic model. A cost analysis refers to the measure of costs, for instance comparing the total cost between different treatments or healthcare interventions. With cost-effectiveness analysis, both the cost and the effect of an intervention are taken into account. A commonly used model in healthcare is the cost-utility analysis with quality-adjusted life-years (QALY) as an outcome measure. Measuring the gain in quality of life set to a price, helps decision-makers to prioritize between alternatives. A cost analysis usually covers costs arising from use of resources within the healthcare sector (direct costs), and also costs for the patient and family including productivity loss (indirect costs), set to a price, in order to compare costs between alternative treatments or healthcare interventions [Drummond et al. 2015].

In this thesis, the impact of lymphadenectomy on HRQoL was analyzed using the three-level version of the EuroQol five dimension form (EQ-5D-3L) health index. Provided that the HRQoL does not differ between the investigated groups, it can be assumed that the lowest cost in a utility analysis is the most cost-beneficial. Under such circumstances, a cost analysis is considered sufficient and valid to evaluate the health economical aspects [The Pharmaceutical Benefits Board 2003]. 


\section{Clinical considerations and evolvement of hypotheses}

In my clinical practice, I reflected on the fact that many questions seemed to remain unanswered when counseling women with endometrial cancer prior to surgery, especially about the postoperative recovery. The prognosis concerning survival is for obvious reasons a key issue for the woman, but the consequences of the surgery and adjuvant oncologic treatment in terms of physical bodily and psychological impact are other important topics that are brought up. Prior to the introduction of the National Guidelines for Treatment of Endometrial Cancer in 2010, lymphadenectomy was used sporadically in the treatment of endometrial cancer in Sweden. The guidelines from 2012 recommended systematic use of a comprehensive lymphadenectomy in surgery of high-risk apparent early-stage endometrial cancers. The recommendation implied that approximately one-third of women with endometrial cancer should undergo lymphadenectomy. This also changed greatly in the preoperative counseling. What are the consequences of lymphadenectomy and what are the risks for developing lymphedema? Am I at risk? How will lymphedema affect me? These are questions I often meet in the preoperative counseling of women with endometrial cancer. Many women have seen and heard stories about women with lymphedema after breast cancer and are deeply worried about being affected by lymphedema. The majority of women accept the recommendation of treatment of the endometrial cancer anyhow, but some women cannot accept being exposed to the risk of developing lymphedema. For these women, it is very unsatisfactory not to be able to give adequate information about realistic risks since the literature seems to present inconsistent information. As a first step to approaching the questions about the consequences of surgery and lymphadenectomy in endometrial cancer and the risk of developing lymphedema, risk factors and the impact on quality of life, we performed a systematic review of the literature [Lindqvist et al. 2017]. We found that the incidence of lymphedema after endometrial cancer varied substantially, between $0 \%$ and $50 \%$. The reported risk factors for lymphedema were discrepant, but the impact on quality of life was uniformly negative. We drew the conclusion that the incidence of lymphedema, risk factors and impact on quality of life were not yet established. Since there is no 'gold standard method to determine lymphedema clinically and a variety of methods have been used in the literature, in our study we investigated both subjective and objective methods for assessing lymphedema to determine the incidence and risk factors of lymphedema, and evaluate the impact of lymphedema on quality of life. In addition, from a health care perspective we found it important to evaluate the health economics in relation to the use of lymphadenectomy in endometrial cancer treatment, and in relation to lymphedema.

Based on the considerations described above, a number of hypotheses were proposed, leading to research questions with specific aims. 


\section{Hypotheses}

- Women with endometrial cancer treated with surgery including lymphadenectomy have a higher incidence of lymphedema compared with those that do not undergo lymphadenectomy, both when measured subjectively and objectively.

- Risk factors for lymphedema are not consistent when different methods to determine lymphedema are used.

- Women with endometrial cancer treated with surgery including lymphadenectomy have lower health-related quality of life compared with those operated without lymphadenectomy.

- Women with endometrial cancer treated with surgery including lymphadenectomy are more likely to develop complications, have more readmittance and therefore higher health care costs compared with those that are not exposed to lymphadenectomy. 


\section{Aims}

\section{General aim}

To study the long-term consequences of treatment of endometrial cancer with emphasis on lymphadenectomy, the development of lymphedema, impact on health-related quality of life, and health economy.

\section{Specific aims}

- To determine the incidence of lymphedema, as measured by different methods, one year after surgery.

- To determine risk factors for lymphedema, as measured by different methods, one year after surgery.

- To analyze the impact of lymphadenectomy and lymphedema on health-related quality of life one year after surgery.

- To evaluate the hospital costs associated with the use of lymphadenectomy in the treatment of endometrial cancer, and lymphedema. 


\section{Material and methods}

\section{Study design}

The thesis is based on a prospective observational multicenter study, the LASEC trial, (Lymphadema After Surgery of Endometrial Cancer) conducted in Sweden at four university hospitals, seven central hospitals, and four county hospital (Table 6) in the period June 2014 to January 2018.

Table 6. Participating clinics and hospitals.

\begin{tabular}{|l|l|l|}
\hline Level of hospital & Department & Hospital and city \\
\hline University hospital & Dept. of Ob/Gyn & University hospital, Linköping \\
& Dept. of Ob/Gyn & Sahlgrenska university hospital, Gothenburg \\
& Dept. of Ob/Gyn & Akademiska university hospital, Uppsala \\
\hline & Dept. of Ob/Gyn & Norrlands university hospital, Umeå \\
\hline & Dept. of Oncology & University hospital, Linköping \\
\hline & Dept. of Ob/Gyn & Blekinge hospital, Karlskrona \\
\hline & Dept. of Ob/Gyn & Falun hospital, Falun \\
\hline Central hospital & Dept. of Ob/Gyn & Gävle hospital, Gävle \\
\hline & Dept. of Ob/Gyn & Karlstad central hospital, Karlstad \\
\hline & Dept. of Ob/Gyn & Skaraborg hospital, Skövde \\
\hline & Dept. of Ob/Gyn & Sundsvall regional hospital, Sundsvall \\
\hline & Dept. of Ob/Gyn & Västerås central hospital, Västerås \\
\hline & Dept. of Ob/Gyn & Eksjö highland hospital, Eksjö \\
\hline & Dept. of Ob/Gyn & North Älvsborg county hospital, Trollhättan \\
\hline County hospital & Dept. of Ob/Gyn & Varberg hospital, Varberg \\
\hline & Dept. of Ob/Gyn & Västervik hospital, Västervik \\
\hline
\end{tabular}

\section{Population}

The participants were women with newly diagnosed endometrial cancer, who were admitted to the participating hospitals for surgical treatment. The women underwent preoperative assessment according to the requirements in the SNGEC [SNGEC 2012], and if they were found to have apparent early-stage cancers, i.e., without clinical or imaging diagnostic signs of disease outside the uterus, they were eligible for the study. The inclusion and exclusion criteria for participating in the LASEC trial are described in Table 7.

\section{Surgery}

The surgery was conducted according to the recommendations in the SNGEC. The surgery of endometrial cancer categorized as high-risk comprised lymphadenectomy, whereas lymphadenectomy was omitted in low-risk endometrial cancer (Table 3). The method of surgery was at the surgeon's discretion. All patients received prophylactic antibiotics and antithrombotic. 


\section{Inclusion criteria}

- Age $\geq 18$ years.

- Histopathologically proven endometrial cancer (including carcinosarcoma) that is assumed by the gynecological oncologists or gynecological surgical oncologists to be early-stage (i.e., without clinical or imaging diagnostic signs of spread outside the uterus).

- Planned surgery comprises simple or radical hysterectomy, with or without pelvic/para-aortic lymphadenectomy according to the recommendations in the Swedish National Guidelines for Endometrial Cancer.

- WHO performance status $\leq 2$.

- Understands and speaks Swedish.

- Gives informed consent to participate in the study.

\section{Exclusion criteria}

- Uterus sarcoma.

- Previous pelvic and/or paraaortic lymphadenctomy.

- Previous pelvic radiation therapy.

- Venous or arterial insufficiency of the lower limbs currently requiring treatment.

- Known congenital or acquired malformations of the lymphatic system.

- Previous or current treatment of lymphedema of the upper or lower limbs.

- Physically disabled to such a degree that early postoperative ambulation may be impossible or strongly reduced.

- Mental disability or severe psychiatric illness.

\section{Adjuvant oncological treatment}

Postoperatively, a new risk-assessment was performed, based on the histopathology report from the surgery. Adjuvant oncological treatment was recommended provided that the risk-assessment indicated high risk in accordance with the SNGEC. In these cases, chemotherapy, radiation therapy, or combined therapy was given. Radiation therapy was given as external beam therapy, vaginal brachytherapy, or combined vaginal brachytherapy and external beam therapy. Standard adjuvant chemotherapy was four courses of carboplatin and paclitaxel given every third week.

\section{Follow-up}

The study period for each participant was one year. The women were assessed on four occasions; preoperatively (baseline), at four to six weeks, six months, and one year postoperatively. The extent of the assessments on each occasion is shown in Table 8.

On each follow-up occasion and during the hospital stay clinical data were prospectively collected. Adverse events, readmissions and re-operations were addressed specifically at the follow-up interviews.

\section{Methods of assessing lymphedema}

Lymphedema was determined by three different methods. Two were objective methods, one using systematic circumferential measurements of the leg enabling calculation of leg volumes, 
and the second using clinical evaluation and grading of lymphedema of the legs. There was one subjective method using the patient-reported perception of swelling of the legs.

Table 8. Overview of assessments in relation to timing of follow-up in the LASEC trial.

\begin{tabular}{|c|c|c|c|c|}
\hline \multirow[t]{2}{*}{ Assessments } & \multicolumn{4}{|c|}{ Timing } \\
\hline & Baseline & 4-6 weeks & Six months & One year \\
\hline Collection of clinical data & $\mathrm{X}$ & $\mathrm{X}$ & $\mathrm{X}$ & $\mathrm{x}$ \\
\hline Clinical examination including vaginal ultrasonography & $\mathrm{X}$ & $\mathrm{X}$ & $\mathrm{X}$ & $\mathrm{X}$ \\
\hline Registration of adverse events & & $\mathrm{X}$ & $\mathrm{X}$ & $\mathrm{X}$ \\
\hline Systematic leg circumference measurements & $\mathrm{X}$ & $\mathrm{X}$ & $\mathrm{X}$ & $\mathrm{X}$ \\
\hline Clinical grading of leg lymphedema & $\mathrm{X}$ & $\mathrm{X}$ & $\mathrm{X}$ & $\mathrm{X}$ \\
\hline \multicolumn{5}{|l|}{ Health-related Quality of Life assessments } \\
\hline \multicolumn{5}{|l|}{ Generic questionnaires } \\
\hline EQ-5D-3L & $\mathrm{X}$ & $\mathrm{X}$ & $\mathrm{X}$ & $X$ \\
\hline SF-36 & $\mathrm{X}$ & $\mathrm{X}$ & $\mathrm{X}$ & $\mathrm{X}$ \\
\hline \multicolumn{5}{|l|}{ Lymphedema-specific questionnaire } \\
\hline LYMQOL & $\mathrm{X}$ & $X$ & $X$ & $X$ \\
\hline
\end{tabular}

\section{Leg volume measurement}

The leg volume was estimated using systematic circumference measurements of the leg enabling calculation of a leg volume by applying the cone method described by Sitzia [Sitzia et al. 1995]. The leg circumference was measured from a fixed point (determined at the baseline measurement as the narrowest part of the lower leg just above the malleolus) to the groin at four $\mathrm{cm}$ intervals (Figure 11).

The measurements were conducted by skilled lymphedema therapists or trained nurses. Ideally, the assessments (leg measurements and clinical grading) should be conducted by the same lymphedema therapist on all occasions.

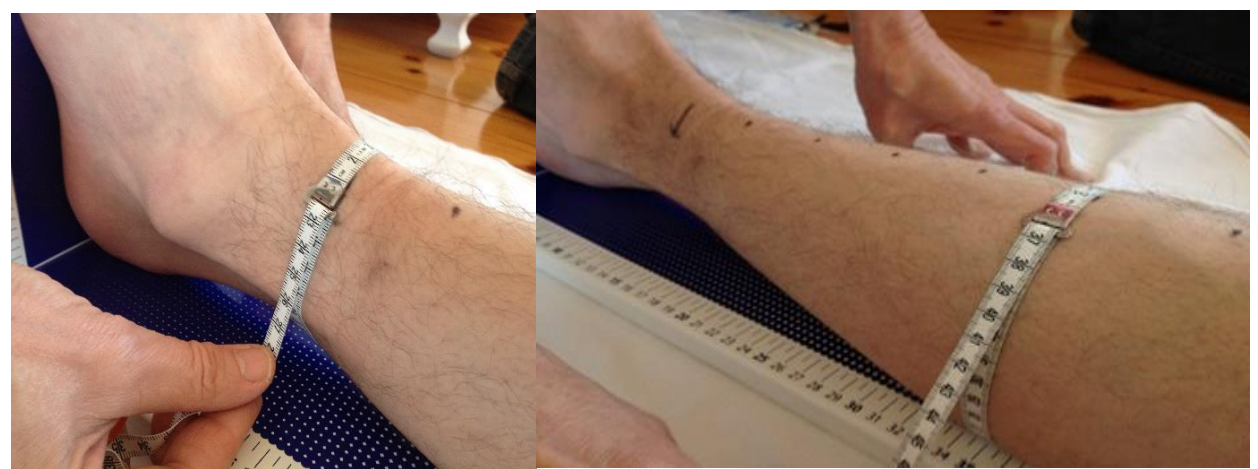

A

B

Figure 11. Systematic circumferential measurement of the leg. A. Circumference measurement at the 0-point (the fix point at the narrowest part of the leg just above the malleolus). B Circumference measurement $20 \mathrm{~cm}$ above the 0-point. (@) Eva Ahlner. Reprinted with kind permission from the copyright holder)

The measurements (see Appendix 1) were registered and entered manually into the software Calculation of Volume of Edema ${ }^{\odot}$ (Wallenius Consulting, Rabeniusvägen 24, 75655 Uppsala, 
Sweden). The leg volume was calculated for each leg. The person who conducted the measurements was not involved in the input of the data in the software for volume calculation and consequently was blinded to the results of the volume calculation.

The changes in volumes between baseline and the one-year measurements were calculated and categorized according to the relative increase in three categories; $<10 \%, 10-20 \%$, and $>20 \%$ [Sun et al. 2016, Hidding et al. 2018, Executive Committee of the International Society of Lymphology 2020]. An increase in relative volume $\geq 10 \%$ was considered as lymphedema [Executive Committee of the International Society of Lymphology 2020].

Since leg volume is strongly correlated with BMI we both used the crude estimated volume and the BMI adjusted (BMI-standardized volume) as measures of leg volume for determination of lymphedema. The BMI-standardized leg volume was determined on each occasion of measurement by the formula:

BMI-standardized volume $=$ estimated leg volume $*$ mean BMI of the group on the occasion of measurement de facto BMI on the occasion of measurement

\section{Clinical evaluation of the legs}

Clinical evaluation and clinical grading of lymphedema was performed by the lymph therapists or trained nurses according to the method described by Bruna et al. [Bruna et al. 1999]. The method includes inspection, palpation, effect of elevation, and function of the leg (Table 9). Each leg is assessed separately.

Table 9. The clinical classification of lymphedema according to Bruna.

\begin{tabular}{|c|c|c|c|c|}
\hline $\begin{array}{l}\text { Grade of } \\
\text { lymphedema }\end{array}$ & $\begin{array}{l}\text { Inspection of extrem- } \\
\text { ity }\end{array}$ & $\begin{array}{l}\text { Palpation of extrem- } \\
\text { ity }\end{array}$ & Effect of elevation & Function of legs \\
\hline Grade 0 & Normal & Normal & None & Normal \\
\hline Grade 1 & Normal & $\begin{array}{l}\text { Pitting edema on ap- } \\
\text { plication of pressure }\end{array}$ & $\begin{array}{l}\text { Edema disappears or } \\
\text { decreases markedly }\end{array}$ & Normal \\
\hline Grade 2 & Yellowish discoloration & $\begin{array}{l}\text { Early skin thickening, } \\
\text { pitting edema on appli- } \\
\text { cation of pressure }\end{array}$ & $\begin{array}{l}\text { Edema decreases } \\
\text { moderately }\end{array}$ & $\begin{array}{l}\text { Decreased mobility } \\
\text { and some decrease in } \\
\text { function }\end{array}$ \\
\hline Grade 3 & $\begin{array}{l}\text { Lichenification, small } \\
\text { vesicles often appear, } \\
\text { early, small keratotic } \\
\text { papules }\end{array}$ & $\begin{array}{l}\text { Skin thickening, little } \\
\text { pitting on application } \\
\text { of pressure }\end{array}$ & $\begin{array}{l}\text { Edema decreases } \\
\text { minimally }\end{array}$ & $\begin{array}{l}\text { Marked function loss, } \\
\text { impairment of fine } \\
\text { movement and loss of } \\
\text { joint flexibility }\end{array}$ \\
\hline Grade 4 & $\begin{array}{l}\text { Lichenification, yellow- } \\
\text { ish discoloration, in- } \\
\text { creased pigmentation, } \\
\text { weeping vesicles, ker- } \\
\text { atotyic papules of var- } \\
\text { ying sizes }\end{array}$ & $\begin{array}{l}\text { Skin thickening, no pit- } \\
\text { ting on application of } \\
\text { pressure }\end{array}$ & No decrease in edema & $\begin{array}{l}\text { Marked functional } \\
\text { loss, movements are } \\
\text { markedly impaired }\end{array}$ \\
\hline
\end{tabular}

The method uses a five-level grading scale, ranging from 0 to 4 . Grade $0=$ all normal, Grade 1 $=$ pitting edema that disappears with elevation, Grade $2=$ discolored skin with pitting edema that decreases with elevation, with slight function disability. Grade $3=$ increased skin changes, minimal pitting response, minimal change with elevation and increased function disability. 
Grade 4 = increased skin changes with loss of pitting reaction, no response with elevation and significant loss of function.

The change between the baseline and the one-year assessment was categorized as 'no lymphedema' provided both measurements on both legs were Grade 0 , or as 'unchanged' if the grade $>$ Grade 0 was similar on the two occasions. The change was categorized as 'aggravated' if the baseline was > Grad 0 and the one-year grading was higher than the baseline grading in one of the legs, and as 'de novo' if the baseline was Grade 0 and the one-year was > Grade 0 in one of the legs.

\section{Patient's perception of leg swelling}

The Swedish version of the Lymphedema quality of life questionnaire (LYMQOL), (described below) contains two questions concerning the patient's perception of swelling of the legs, one for each leg. Swelling was classified into four grades: 'Not at all'; 'A little'; 'Quite a bit' or 'A lot' 'Not at all' was categorized as 'no lymphedema' whereas all the other classes were categorized as 'lymphedema' [Wedin et al. 2020].

The change in degree of perceived swelling from baseline to the one-year assessment was categorized as 'no swelling' if both legs were graded 'Not at all' on both occasions, and as 'unchanged swelling' provided that the swelling was graded as 'A little' or more and the same on both occasions in both legs. The category 'De novo swelling' was used if both legs at baseline were graded as 'Not at all' and at least one of the legs at the one-year assessment was graded as 'A little' or more. Likewise, the category 'progress of swelling' was used if a swelling graded as at least 'A little' at baseline in one of the legs increased in grade of swelling at the one-year assessment.

\section{Assessment of lymphocyst and lymphatic ascites}

Vaginal ultrasonography was performed by skilled gynecologists in conjunction with the gynecological examination at the follow-up visits in order to evaluate the occurrence of lymphatic ascites and/or lymphocysts (encapsulated fluid).

\section{Quality assessment of the LASEC trial}

The LASEC trial was conducted according to the guidelines of the International Conference on Harmonisation -Good Clinical practice (ICH-GCP) [International Conference on Harmonisation 2002]. An independent person monitored the trial according to the requirements of Good Clinical Practice.

\section{Health-Related Quality of Life assessments}

To assess the health-related quality of life, three HRQoL inventories were used: two generic HRQoL forms, the EQ-5D-3L, and the SF-36, and a lymphedema-specific form, the LYMQOL [Keeley et al. 2010, Wedin et al. 2020]. 


\section{The EQ-5D-3L}

EQ-5D-3L is a widely used instrument for measuring generic health status, and describes five dimensions: mobility, self-care, usual activities, pain/discomfort, and anxiety depression. The respondents are requested to answer questions on each of the five dimensions describing the severity of impairment of the dimension on a three-level scale ('no problems', 'moderate problems', and 'severe problems'). This enables the definition of a unique health state with $3^{5}=243$ combinations of answers. This health state can be converted into a preference weight, using a weighted health state index by applying scores from EQ-5D-3L value sets elicited from the general population, to calculate the HRQoL. The index ranges from -0.594 to 1 . Zero indicates the state of death and one indicates full health. The EQ-5D-3L has been translated into Swedish and validated in Sweden [Burström et al. 2001].

\section{The SF-36}

The 36-item Short Form Health Survey (SF-36) is a broadly used generic instrument for evaluating HRQoL. The SF-36 consists of 36 questions that are divided into eight subscales: physical functioning (PF), role limitations as a result of physical problems (RP), bodily pain (BP), general health perception (GH), vitality (VT), social functioning (SF), role limitations due to emotional problems (RE) and mental health (MH), and two summary component scales; a physical component summary (PCS), and a mental component summery (MCS). Each scale has a score, which is the weighted sum of the questions in their section. Each scale is transformed into a 0-100 scale. A higher score indicates better health. The SF-36 is translated into Swedish and has been validated in a Swedish setting [Sullivan et al. 1995].

\section{The LYMQOL}

The LYMQOL, originally developed by Keeley et al., is a symptom-specific tool for lymphedema and consists of a form for lymphedema for the arms and one for lymphedema of the legs [Keeley et al. 2010]. In this study, only the leg version of the LYMQOL was used. The Swedish version of the LYMQOL (the leg version) is shown in Appendix 2.

The leg version of the LYMQOL consists of 28 items. Twenty-seven items are categorized into four domains. The domains represent: function, appearance/body image, symptom and mood. Twenty-seven of the items are scored as Not at all (=1); A little (=2); Quite a bit (=3) or A lot $(=4)$. The total score for each domain is reported as the mean of the score of the items included in the domain. If more than $50 \%$ of items in a domain are not answered, the score of the domain is set at 0 . Consequently, the scores range from 0 to 4 . Higher scores indicate lower HRQoL. Item number 28 comprises a measure of the global HRQoL, and is reported on a scale from 0 (poor HRQoL) to 10 (excellent HRQoL) as the global score.

In order to use LYMQOL in a Swedish context, the LYMQOL has been validated in a Swedish setting [Wedin et al. 2020]. Swedish cancer patients with lymphedema were invited to participate and asked to fill in the Swedish LYMQOL on two occasions with a week's interval. A summary of the validation is presented in Table 10 . 
Table 10. Summary of the validation of the Swedish LYMQOL in a Swedish setting of 106 persons, both men and women, diagnosed with lymphedema after cancer treatment.

\begin{tabular}{|c|c|}
\hline Method & Summary \\
\hline Forward and backward translation & $\begin{array}{l}\text { Nine translators agreed on the final version of the question- } \\
\text { naire }\end{array}$ \\
\hline Content and face validity & $\begin{array}{l}\text { Questionnaire was easy, clear and not too long. Pelvic - and } \\
\text { hand/feet swelling and sexual aspects were areas suggested } \\
\text { missed out }\end{array}$ \\
\hline Construct validity & $\begin{array}{l}\text { Was high in both arm and leg versions compared with the } \\
\text { Short Form- } 36 \text { (used as the 'gold standard') } \\
\text { The association between the degrees of perceived } \\
\text { lymphedema and the LYMQOL leg version was significant in } \\
\text { all domains }\end{array}$ \\
\hline Internal consistency & $\begin{array}{l}\text { The internal consistency was acceptable to excellent with } \\
\text { Cronbach's alpha values ranging from } 0.79 \text { to } 0.94\end{array}$ \\
\hline Reliability -test-retest & $\begin{array}{l}\text { Was very good for the leg version (Spearman's coefficients } \\
0.90 \text { ) }\end{array}$ \\
\hline
\end{tabular}

It was concluded that the Swedish LYMQOL (leg version) had excellent feasibility, showed high face validity, excellent internal consistency, and high construct validity. The reliability was very good for the leg version.

The LYMQOL may be seen as a useful simple tool for measuring lymphedema and lymphedema-related HRQoL aspects in the limbs in clinical practice as well as in a scientific context. [Wedin et al. 2020]

\section{Health economy}

\section{Hospital costs}

The calculations of costs followed the structure of a cost analysis [Drummond et al. 2015]. The calculation of hospital costs was based on the cost per patient (CPP) principles [Swedish municipalities and regions 2020]. CPP is a method to estimate healthcare costs per care contact and patient. CPP means that medical data and costs are linked to an individual patient. In this study, the 2020 CPP list from the University hospital in Linköping was used. The prices in the CPP list for treatment of endometrial cancer were based on the costs of 128 women treated in 2020 for endometrial cancer at the University hospital in Linköping, Sweden. The CPP list comprises all relevant resources related to the operation, postoperative care, stay in the hospital ward, readmissions and unplanned visits after discharge. Overhead costs such as development, rent for premises, and reinvestigations of standard equipment are equally distributed in all CPP costs.

The costs related to the treatment were identified in the CPP list and are presented in Table 11: hospital stay, surgery, post-anesthesia care unit, histopathology analysis, adjuvant oncological treatment (chemotherapy and radiation therapy), unplanned outpatient visits within six weeks after discharge, readmissions within one year after surgery, attributed to conditions related to the primary surgery, with or without concomitant surgery. 
All costs are reported in Swedish Crowns (SEK). The average exchange rate in 2020 for $1 €$ was 10.4867 SEK and for 1 US \$ was 9.2037 SEK according to the Swedish central bank, Sveriges Riksbank [Swedish Riksbank].

Hospital stay was calculated in days as the difference between date of admission and date of discharge. The cost per day for hospital stay includes costs for all ward staff, including the surgeon, postoperative treatments including re-operations during the hospital stay, treatment of postoperative complications during the hospital stay including laboratory tests, and diagnostic imaging and interventions.

Surgery time was measured in minutes, and the surgery cost is calculated based on costs/minute. The cost/minute of surgery includes all staff costs, including the surgical nurses and assisting nurse, the anesthesiologist, the nurse anesthetist and assisting nurse, standard instruments, surgical drapes, sterilization of instruments, and surgeon's and procedure-specific material costs, but not costs for robotic equipment. The cost/minute is specified as the cost charged in 2020 by the surgical ward.

Post-anesthesia care unit (PACU) cost included all costs generated in the PACU and was noted as the mean cost for each mode of surgery as registered in the CPP, based on all endometrial cancer patients treated in the University Hospital in Linköping in 2020.

Robotic equipment. The robotic system used was the $d a$ Vinci ${ }^{\circledR}$ Si System. The cost for the robotic equipment was set at a fixed rate in the CPP list, based on 500 robotic procedures annually, and added to the surgery costs when robotic surgery was conducted. The fixed costs included the depreciation of the robotic system (depreciation time of eight years), service costs, and a standard set of robot-specific instruments (Maryland bipolar forceps, needle driver, monopolar scissors) and draping.

Histopathology costs in the CPP list were based on the mean costs for all endometrial cancer patients treated in 2020 in the University hospital in Linköping according to mode of surgery.

Adjuvant chemotherapy cost. Adjuvant treatment was given based on the occurrence of prognostically unfavorable factors such as histological type and FIGO stage according to the SNGEC (SNGEC 2012). The standard adjuvant chemotherapy consisted of four courses of paclitaxel and carboplatin given every third week in a day care department. The cost for standard adjuvant chemotherapy was based on the CPP list for the department of Oncology in the University hospital in Linköping.

Adjuvant radiation therapy cost was likewise based on the CPP list for the department of Oncology in the University Hospital in Linköping. The cost was set as a standard radiation therapy and did not discriminate between the modes of radiation, e.g. external beam or vaginal brachytherapy.

$\underline{\text { Readmission cost }}$ was indicated as a fixed cost that corresponded to the cost for hospital stay for one day.

Readmission with surgery cost was indicated as a fixed cost that corresponded to the summary of the CPP cost for open low-risk endometrial cancer surgery without lymphadenectomy and the costs for two days of hospital stay.

Unplanned outpatient visit cost was indicated as the cost of an outpatient visit in the CPP list. 


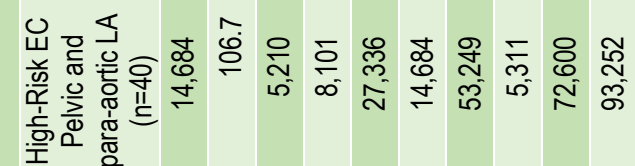

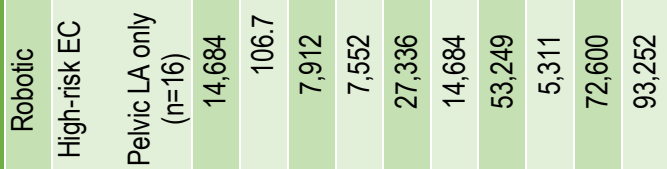

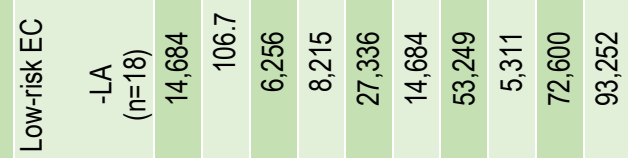<smiles>C=CC=CC</smiles>

(1)

젛 응

$$
\text { (2) }
$$

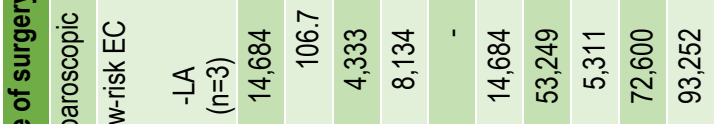

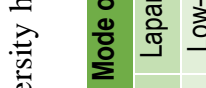

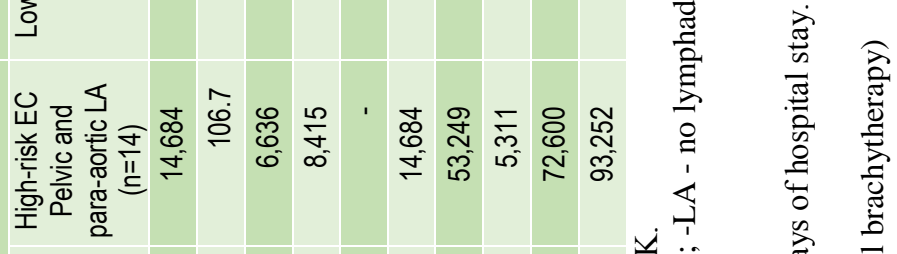
U

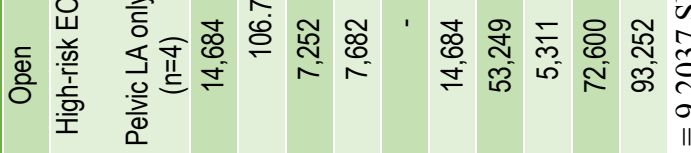

‡ี

离

(1)

䆓:

$\Xi$ స్

苍

¿

范

चี

$\sum^{\mathbb{\Phi}}$.

二 ت

它:

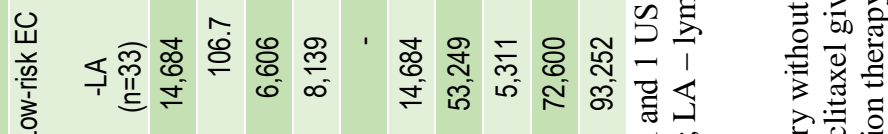

ते ฮ

홍

ส

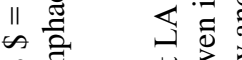

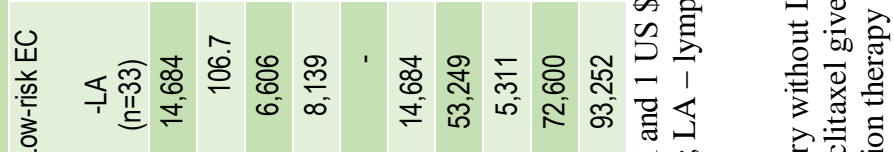

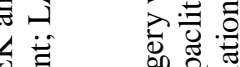

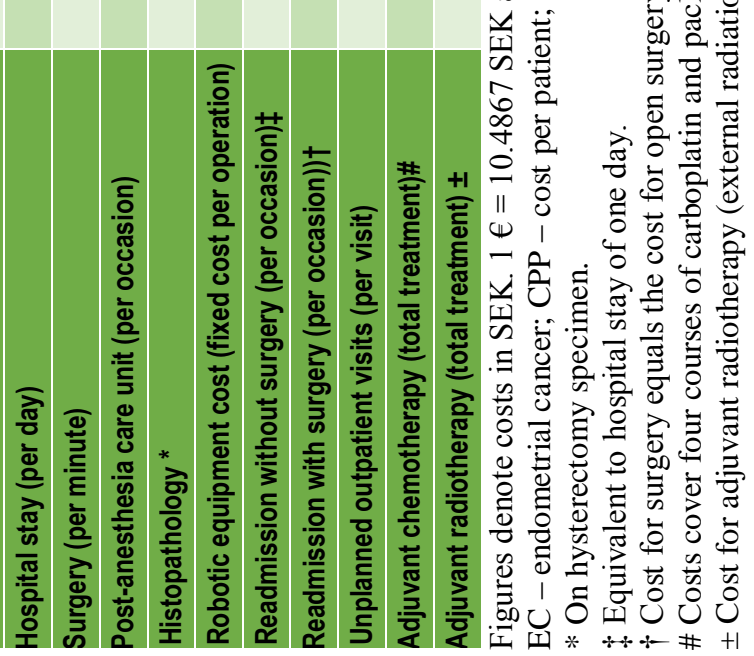




\section{Ethical approval and considerations}

The LASEC study was conducted in accordance with the World Medical Association's Declaration of Helsinki from October 2013 concerning Ethical Principles for Medical Research Involving Human Subjects [World Medical Association 2013]. The study was approved by the Regional Ethics Board of Linköping University (Dnr 2013/373-31 with amendments Dnr 2014/86-32; Dr nr 2014/175-32, and Dnr 2015/26-32)

To cherish the participant's integrity and anonymity, and safeguard participant safety are keystones in human research. In addition, participation in research must be voluntary and based on informed consent. All these five issues were met in the LASEC trial. The study did not include new interventions but was aimed at investigating the effects of lymphadenectomy as recommended in the treatment of endometrial cancer in the prevailing national guidelines for treatment of endometrial cancer at the time of the study. Although the use of lymphadenectomy was clearly defined in the guidelines and thus in general accepted by the medical profession and health care authorities, the use of lymphadenectomy in endometrial cancer may raise ethical considerations. The long-term consequences of lymphadenectomy are not well established, and in particular lymphedema has been poorly researched. Thus, by establishing more knowledge about the development of lymphedema and the impact of lymphadenectomy on women's lives in endometrial cancer treatment this thesis will hopefully also contribute to clarifying ethical aspects. 


\section{Statistics}

All statistical analyses were performed using the software TIBCO Statistica ${ }^{\mathrm{TM}}$, version 13.5 (TIBCO Software Inc, Palo Alto, CA 94303, USA).

\section{Sample size estimation of the LASEC trial}

Estimation of the sample size of the LASEC trial was based on assumptions of differences in the incidence of lymphedema, increase in leg volumes, and HRQoL comparing the group of women who underwent surgery for endometrial cancer including lymphadenectomy and the group without lymphadenectomy, and not receiving adjuvant radiation therapy. It was assumed that $30 \%$ of the women who underwent lymphadenectomy and $10 \%$ of the women without lymphadenectomy would receive adjuvant radiation therapy. The assumptions were 1) the incidence of lymphedema one year after surgery was $15 \%$ in women who had lymphadenectomy and $0 \%$ among those without lymphadenectomy, 2) the difference in mean leg volume of women with lymphedema and women without lymphedema was $600 \mathrm{~mL}$ (one standard deviation (SD) 1,000 mL), and 3) the difference in HRQoL, as measured by the EQ-5D-3L health index, between women with and without lymphadenectomy was 0.1 and the SD of the index was 0.2 . With an expected lapse of $10 \%$, the sample size was estimated to be 130 in each group (with or without lymphadenectomy), in total 260 women, in order to detect a significant difference at a $5 \%$ significance level with $90 \%$ power.

\section{Descriptive statistics}

The measures of central tendency of continuous data are expressed as mean or median, and the measures of dispersion as one SD or interquartile range (IQR), respectively.

Categorical data are presented as number and percentage.

\section{Comparative statistics}

In general, normally distributed continuous data were analyzed by means of parametric tests and not-normally distributed data by means of non-parametric tests. Nominal data were analyzed by means of non-parametric tests. The level of significance was set at $5 \%$.

The various statistical tests used in the thesis are summarized in Table 12. 
Table 12. Summary of statistical tests used in the thesis in relation to type and set of data.

\begin{tabular}{|c|c|c|c|}
\hline Type of data & Set of data & Name of statistical test & Post-hoc-test \\
\hline \multirow[t]{6}{*}{ Nominal } & Unpaired & Pearson's Chi-squared test & \\
\hline & Unpaired & Fischer's exact test & \\
\hline & Paired & McNemar test & \\
\hline & Unpaired & Logistic regression, univariate & \\
\hline & Unpaired & Multiple logistic regression with forward stepwise modeling & \\
\hline & Paired & Cohen's kappa inter-observer agreement & \\
\hline \multirow[t]{7}{*}{ Continuous } & Unpaired & Analysis of variance (ANOVA) & \\
\hline & Unpaired & Student's t-test & \\
\hline & Unpaired & Repeated measures ANOVA & Tukey HSD \\
\hline & Unpaired & Mann-Whitney U-test & \\
\hline & Unpaired & Kruskall-Wallis ANOVA & MCMR \\
\hline & Paired & Wilcoxon matched pair test & \\
\hline & Paired & Pearson's correlation coefficient & \\
\hline
\end{tabular}

HSD - honest significant difference; MCMR - multiple comparison of mean ranks for all groups; ANOVA - analysis of variance 


\section{Results and comments}

\section{Description of study population}

The flow chart of the LASEC trial population is presented in Figure 12.

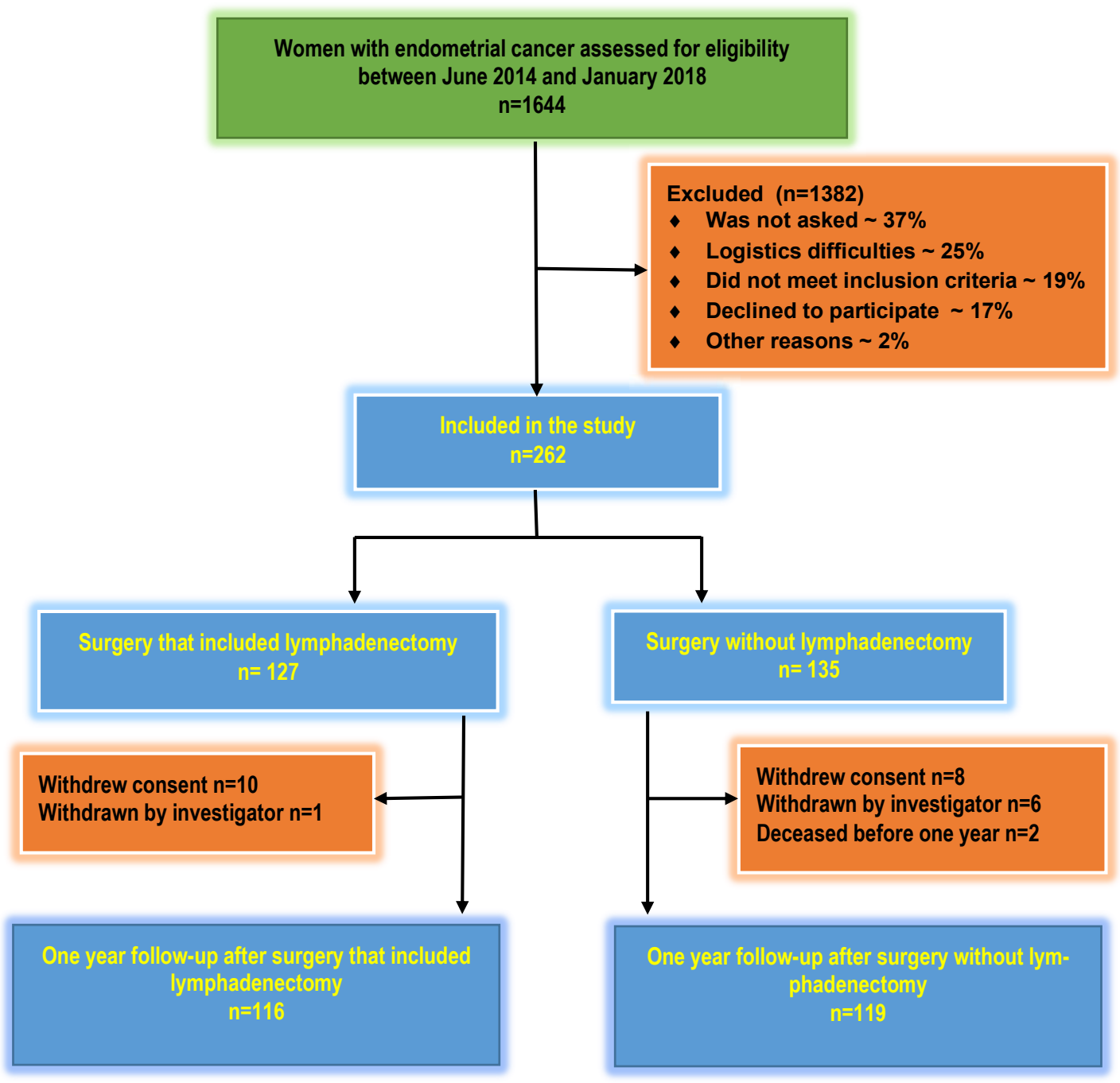

Figure 12. Flow chart of study population in the LASEC trial. 
In total, 262 women were included, and 235 completed the study. Of these, 119 were classified as high-risk endometrial cancer and underwent surgery that included lymphadenectomy, and 116 were classified as low-risk endometrial cancer and lymphadenectomy was not performed on these women. Baseline demographic and clinical data of the participating women in relation to the performance of lymphadenectomy are presented in Table 13

Table 13. Demographic and clinical baseline data in relation to performing lymphadenectomy.

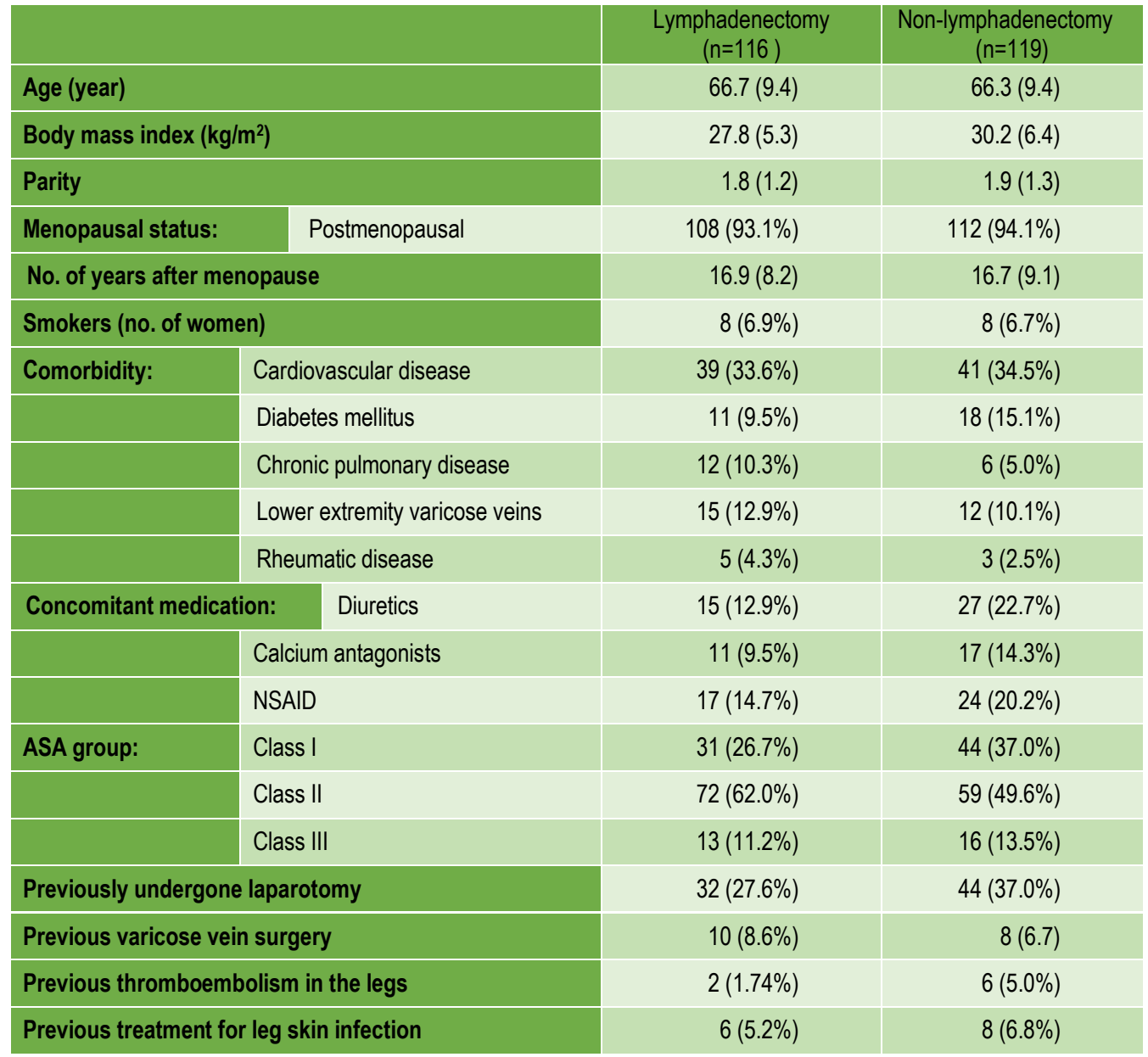

Figures denote mean and (one standard deviation) or number of women and (per cent).

ASA- American Society of Anesthesiologists. NSAID - non-steroidal anti-inflammatory drug. 
The intra- and postoperative data are shown in Table 14.

Table 14 Intra- and postoperative data in relation to performing lymphadenectomy.

\begin{tabular}{|c|c|c|}
\hline & $\begin{array}{l}\text { Lymphadenectomy } \\
\qquad(n=116)\end{array}$ & $\begin{array}{l}\text { Non-lymphadenectomy } \\
\qquad(n=119)\end{array}$ \\
\hline \multirow[t]{3}{*}{ Hysterectomy technique: } & $74(63.8 \%)$ & $38(31.9 \%)$ \\
\hline & $1(0.9 \%)$ & $34(28.6 \%)$ \\
\hline & $41(35.3 \%)$ & $47(39.5 \%)$ \\
\hline Laparoscopic/robotic converted to open surgery & $3(2.6 \%)$ & $2(1.7 \%)$ \\
\hline \multirow[t]{2}{*}{ Mode of hysterectomy } & $104(89.6 \%)$ & $118(99.2 \%)$ \\
\hline & $12(10.3 \%)$ & $1(0.8 \%)$ \\
\hline Operation time (minutes) & $200(83)$ & $94(51)$ \\
\hline Estimated bleeding intraoperatively (ml) & $235(297)$ & $94(117)$ \\
\hline Location of lymph node dissection & $26(22.4 \%)$ & NA \\
\hline Pelvic and para-aortic & $90(77.6 \%)$ & NA \\
\hline \multicolumn{3}{|l|}{ Lower level of pelvic lymph node dissection: } \\
\hline Proximal to the deep circumflex iliac artery & $103(88.8 \%)$ & NA \\
\hline Distal to the deep circumflex iliac artery & $13(11.2 \%)$ & NA \\
\hline \multicolumn{3}{|l|}{ Upper level for para-aortic lymph node dissection } \\
\hline Inferior mesenteric artery & $13(14.4 \%)$ & NA \\
\hline Left renal vein & $77(85.6 \%)$ & NA \\
\hline \multicolumn{3}{|l|}{ Intraoperative complications: } \\
\hline Bleeding exceeding $1000 \mathrm{~mL}$ & $2(1.7 \%)$ & $0(0 \%)$ \\
\hline Urinary tract injury & $0(0 \%)$ & $1(0.8 \%)$ \\
\hline Vascular injury & $2(1.7 \%)$ & $1(0.8 \%)$ \\
\hline Blood transfusion during hospital stay & $3(2.6 \%)$ & $1(0.8 \%)$ \\
\hline Clavien-Dindo complication classification* & $73(62.9 \%)$ & $102(85.7 \%)$ \\
\hline Grade I & $27(23.3 \%)$ & $9(7.6 \%)$ \\
\hline Grade II & $11(9.5 \%)$ & $5(4.2 \%)$ \\
\hline Grade III & $5(4.3 \%)$ & $2(1.7 \%)$ \\
\hline Grade IV & $0(0 \%)$ & $1(0.8 \%)$ \\
\hline Re-operated within six weeks & $7(6.0 \%)$ & $2(1.7 \%)$ \\
\hline Re-operated within one year & $10(8.6 \%)$ & $4(3.4 \%)$ \\
\hline Adjuvant chemotherapy after surgery & $69(59.4 \%)$ & $8(6.7 \%)$ \\
\hline Adjuvant radiotherapy after surgery & $21(18.1 \%)$ & $12(10.1 \%)$ \\
\hline \multicolumn{3}{|l|}{ Mode of adjuvant radiotherapy: } \\
\hline Vaginal brachytherapy & $8(38.1 \%)$ & $6(50.0 \%)$ \\
\hline XRT & $7(33.3 \%)$ & $2(16.7 \%)$ \\
\hline XRT + brachytherapy & $6(28.6 \%)$ & $4(33.3 \%)$ \\
\hline Recurrence of cancer within one year & $3(2.6 \%)$ & $3(2.5 \%)$ \\
\hline Recurrence treated with chemotherapy & $3(2.6 \%)$ & $0(0 \%)$ \\
\hline \multicolumn{3}{|l|}{ Recurrence treated with radiotherapy } \\
\hline Vaginal brachytherapy & 2 & 2 \\
\hline XRT & 1 & 0 \\
\hline XRT+ brachytherapy & 0 & 1 \\
\hline
\end{tabular}

Figures denote mean and (one standard deviation) or number of women and (per cent).

NA - not applicable. XRT= external radiotherapy.

* denotes complications within six weeks postoperatively. 


\section{Distribution according to hospital and lymphadenectomy}

The number of patients in relation to hospital and lymphadenectomy is presented in Table 15 . One of the hospitals did not include its own patients, but admitted high-risk endometrial cancer to a university hospital for surgery where the patient was included in the study. The follow-up visits including leg measurements and clinical grading on these patients were carried out in the referring hospital.

Table 15. Number of patients included in the trial in relation to hospital, performance of lymphadenectomy, and number of withdrawn participants from the study.

\begin{tabular}{|c|c|c|c|}
\hline $\begin{array}{l}\text { City } \\
\text { (in alphabetical order) }\end{array}$ & $\begin{array}{l}\text { Lymphadenectomy } \\
\qquad(\mathrm{n}=127)\end{array}$ & $\begin{array}{l}\text { No lymphadenectomy } \\
\qquad(n=135)\end{array}$ & $\begin{array}{l}\text { Number of women } \\
\text { withdrawn } \\
(n=27)\end{array}$ \\
\hline Eksjö & $0(0 \%)$ & $8(5.9 \%)$ & $3(11.1 \%)$ \\
\hline Falun & $1(0.8 \%)$ & $10(7.4 \%)$ & $0(0 \%)$ \\
\hline Gothenburg (UH) & $30(23.6 \%)$ & $7(5.2 \%)$ & $2(7.4 \%)$ \\
\hline Gävle & $0(0 \%)$ & $7(5.2 \%)$ & $0(0 \%)$ \\
\hline Karlskrona & $5(3.9 \%)$ & $5(3.7 \%)$ & $2(7.4 \%)$ \\
\hline Karlstad & $4(3.1 \%)$ & $14(10.4 \%)$ & $2(7.4 \%)$ \\
\hline Linköping (UH) & $38(29.9 \%)$ & $11(8.1 \%)$ & $5(18.5 \%)$ \\
\hline Skövde & $1(0.8 \%)$ & $6(4.4 \%)$ & $0(0 \%)$ \\
\hline Sundsvall & $5(3.9 \%)$ & $9(6.7 \%)$ & $1(3.7 \%)$ \\
\hline Trollhättan & $6(4.7 \%)$ & $16(11.9 \%)$ & $2(7.4 \%)$ \\
\hline Umeå (UH) & $6(4.7 \%)$ & $2(1.5 \%)$ & $1(3.7 \%)$ \\
\hline Uppsala (UH) & $26(20.5 \%)$ & $23(17.0 \%)$ & $6(22.2 \%)$ \\
\hline Varberg & $5(3.9 \%)$ & $11(8.1 \%)$ & $2(7.4 \%)$ \\
\hline Västervik & $0(0 \%)$ & $6(4.4 \%)$ & $1(3.7 \%)$ \\
\hline
\end{tabular}

Figures denote the number of women, and percent indicates the percentage of all in the group. $\mathrm{UH}$ - university hospital.

Nearly $80 \%$ of the women who had lymphadenectomy (i.e., high-risk endometrial cancer) underwent surgery in a university hospital, whereas the women without lymphadenectomy (i.e., low-.risk endometrial cancer) were operated at the local hospital. This indicated a good compliance with the recommendations in the SNGEC of referring high-risk endometrial cancer patients to tertiary centers for surgery, while treating low-risk endometrial cancer in the local hospital.

\section{Reliability of leg measurements}

To ensure the reliability of leg volume estimations, all lymphedema therapists and the trained nurses conducted a test-re-test measurement of the leg circumferences on a volunteer prior to the start of the study on two occasions. The tests (test 1 and test 2) were conducted with a oneto seven-day interval. In all, 25 lymphedema therapists and trained nurses conducted the test- 
re-test. The circumference measures from these measurements were evaluated by the independent monitor, and entered into the volume-calculator software by the author. The intra-rater deviation in relative volume difference between test 1 and test 2 varied between $-6.4 \%$ and $3.5 \%$ in the right leg and $-16.3 \%$ and $7.7 \%$ in the left leg. The numeric mean difference in relative volume difference of both legs was $2.1 \%$ (2.3\% (SD)) and varied between $0.2 \%$ and $10.9 \%$. The intra-rater variation was considered to be acceptable and allowed those performing the measurements in the trial to be approved.

\section{Measurements and clinical grading of legs}

The compliance with the requirement of the LASEC trial protocol that ideally the same lymph therapist or trained nurse should conduct the assessments on all four occasion was very good. In $64.3 \%$ (151/235) of cases the same person conducted the measurements on all four occasions, and in $15.7 \%(37 / 235)$ and $11.5 \%$ (27/235) of cases, respectively, the same person conducted the measurements on three and two, respectively, of the four occasions. In the remaining $8.5 \%$ (20/235) of cases, the information on the measurement person was either not stated or unclear.

In total, 31 lymph therapists or trained nurses performed the measurements. Twenty-five of these conducted the test-retest of measuring leg circumferences prior to the start of the study. The remaining six persons did not perform the test-retest measuring for various reasons, mainly due to acute situations with the absence of the ordinary staff, or a change of staff during the study period.

\section{Incidence of lymphedema}

Based on the criteria of diagnosis of lymphedema, as described in the Method section, the incidence of lymphedema one year after primary treatment of endometrial cancer varied substantially depending on the method of assessing lymphedema and whether lymphadenectomy was performed (Table 16). Interestingly, as demonstrated by all methods to determine lymphedema, lymphedema did not evolve only after lymphadenectomy, but even when the surgery did not include lymphadenectomy. This phenomenon has previously only been described sporadically in the gynecological literature. Yost et al. described the prevalence of self-reported lymphedema as $36 \%$ when only hysterectomy was performed and as $52 \%$ when lymphadenectomy was included [Yost et al. 2014]. However, the phenomenon has not been evaluated systematically by determining lymphedema by other methods and therefore the pathophysiology is not clarified. A possible explanation might be that the lymphatic pathways to some extent are injured even when a simple hysterectomy is performed for endometrial cancer. Still, it is difficult to explain why lymphedema is not seen after hysterectomy for benign conditions.

The overall incidence of lymphedema was highest when assessed by patient-reported swelling (29.6\%) followed by clinical grading $(17.5 \%)$, crude volume increase $\geq 10 \%$, and lowest for BMI-standardized volume increase $\geq 10 \%(9.5 \%)$. These incidence figures correspond well to 
the variation of incidence of lymphedema reported in the literature where various methods of determining lymphedema are used [Lindqvist et al. 2017]. The results highlight the need for a unanimous definition of lymphedema in clinical and research contexts.

Table 16. Incidence of lymphedema in relation to lymphadenectomy and method of assessment of lymphedema

\begin{tabular}{|l|c|c|c|c|}
\hline & $\begin{array}{c}\text { Volume increase } \\
\geq 10 \%\end{array}$ & $\begin{array}{c}\text { Volume increase } \mathbf{2 1 0} \% \\
\text { (BMI-standardized) }\end{array}$ & $\begin{array}{c}\text { Clinical grading } \\
\text { (de novo or progress) }\end{array}$ & $\begin{array}{c}\text { Patient-reported swelling } \\
\text { (de novo or progress) }\end{array}$ \\
\hline $\mathbf{+}$ LA & $14.9 \%(17 / 114)$ & $15.8 \%(18 / 114)$ & $22.8 \%(26 / 114)$ & $38.1 \%(43 / 113)$ \\
\hline - LA & $9.4 \%(11 / 117)$ & $3.4 \%(4 / 117)$ & $12.2 \%(14 / 115)$ & $21.4 \%(25 / 117)$ \\
\hline $\mathbf{p}^{*}$ & 0.20 & $<0.01$ & 0.03 & $<0.01$ \\
\hline & $12.1 \%(28 / 231)$ & $9.5 \%(22 / 231)$ & $17.5 \%(40 / 229)$ & $29.6 \%(68 / 230)$ \\
\hline $\begin{array}{l}\text { Method- } \\
\text { specific } \\
\text { overall } \\
\text { incidence }\end{array}$ & & & & \\
\hline
\end{tabular}

+LA - lymphadenectomy. -LA- no lymphadenectomy

* Pearson Chi-squared

The incidence of lymphedema differed significantly between the lymphadenectomy group vs. non-lymphadenectomy group, as would be expected when assessed by lymphedema determined by BMI-standardized volume increase, clinical grading and patient-reported swelling. However, when assessed by crude volume increase, no significant difference was observed in the incidence of lymphedema between the +LA and -LA groups. From a clinical point of view this finding seems rather unlikely and strongly indicates that use of crude volume increase $\geq 10 \%$ should be used with great caution in the context of defining lymphedema.

The development in the incidence of lymphedema on the occasions of measurement and in relation to the method of assessing lymphedema is illustrated in Figure 13. 


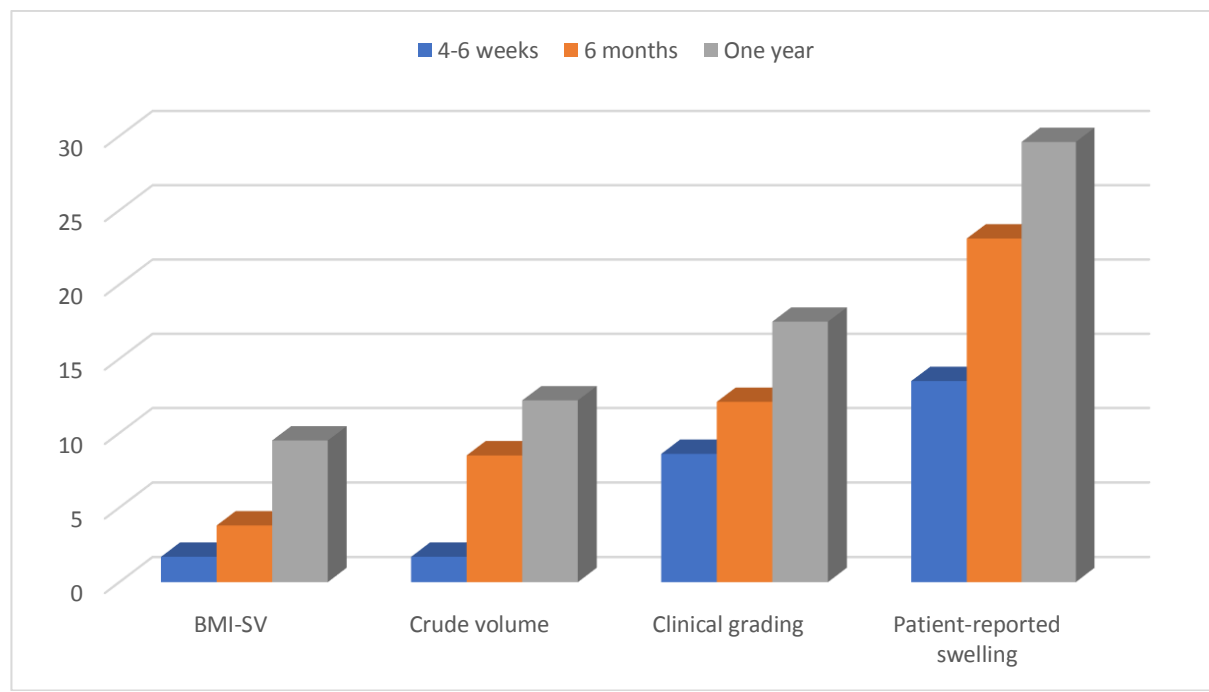

Figure 13. Incidence of lymphedema (in percent) on the occasions of measurement in relation to the method of measuring lymphedema. BMI-SV - body mass index-standardized volume increase $\geq 10 \%$.

A substantial discrepancy was seen in the incidence over time between the methods of measuring lymphedema. At the four- to six-week assessment the incidence was low when assessed by BMI-SV and crude volume increase, whereas the incidence was three to six times higher when assessed by clinical grading or patient-reported swelling. At the six-month assessment a marked increase in incidence was observed, in particular in the methods using volume measurement, but even clinical grading and patient-reported swelling demonstrated a doubling of the incidence compared with the four- to six-week assessment. The incidence increased moderately and almost identically between the various methods to the one-year assessment. These results may indicate that volume measurements will not reveal lymphedema four to six weeks after surgery whereas clinical grading, and in particular patient-reported swelling may reveal early development of lymphedema. It seemed that an assessment six months after surgery may be a suitable time for recognizing lymphedema but still some women may develop lymphedema later, as indicated by the higher incidence at the one-year examination.

\section{Assessing leg volume over time in relation to lymphadenectomy}

The volume of each leg was estimated on the four occasions of assessment. In both legs, the volume was significantly higher in the women who underwent lymphadenectomy than in the women on whom lymphadenectomy was not performed ( $p<0.001$ right leg and $p<0.01$ left leg) (Figure 14). 


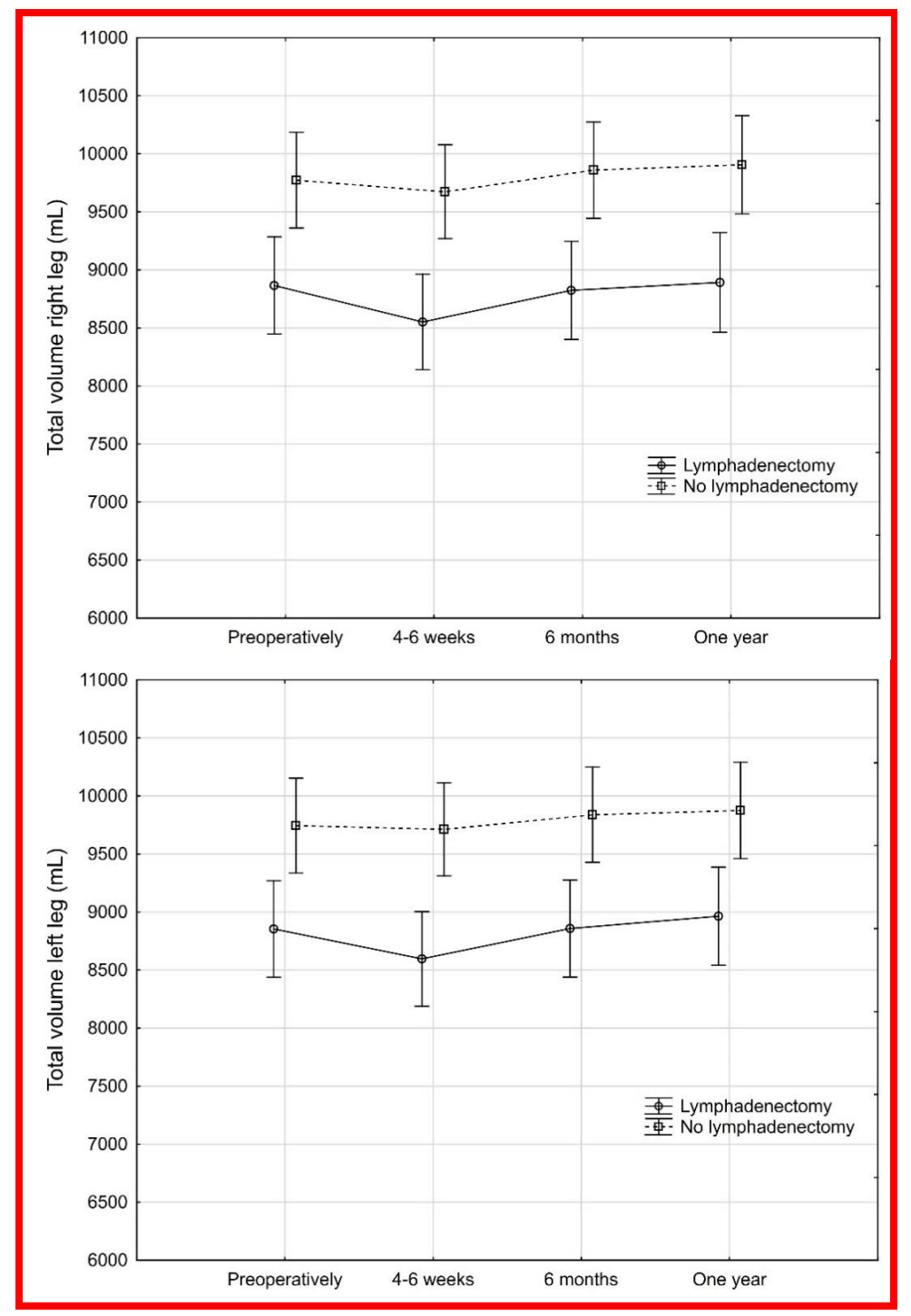

Figure 14. Volume of legs in relation to occasion of measurement in relation to lymphadenectomy. Plots indicate means and bars indicate $95 \%$ confidence interval.

Compared with the volume at baseline a significant decrease in volume was observed at the four- to six-week assessment in both legs. However, at the one-year assessment only the left leg demonstrated a significant increase compared with baseline $(\mathrm{p}<0.01)$.

Since the BMI was significantly higher in the group of women who did not undergo lymphadenectomy compared with women who had lymphadenectomy, and BMI was strongly positively correlated to leg volumes on all occasions (Pearson's correlation coefficients between 0.68 and 
0.69) it seemed obvious to adjust the volumes for BMI. The estimated leg volumes adjusted for BMI for each leg on all four occasions in relation to lymphadenectomy are shown in Figure 15.

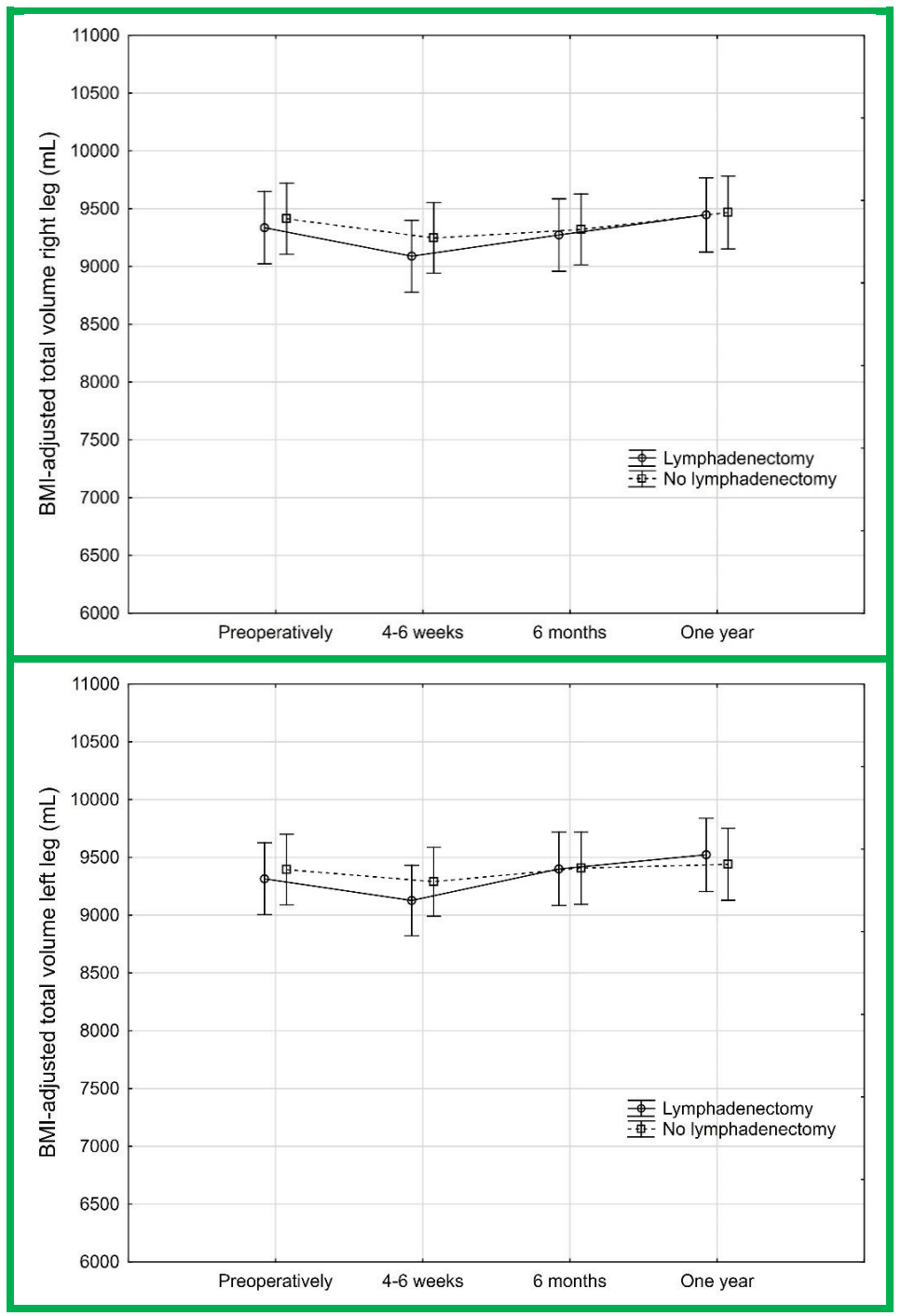

Figure 15. BMI-adjusted volume of legs in relation to occasion of measurement and lymphadenectomy. Plots indicate means and bars indicate $95 \%$ confidence interval.

In the BMI-adjusted models, no significant differences were seen in leg volume between women with and without lymphadenectomy. As for crude volume increase, there was a significant variation over time for the BMI-adjusted volume increase in both legs. This was caused 
by a significant decrease from baseline to the four- to six-week assessment ( $p<0.0001$, for both legs) and a significant increase from baseline to the one-year assessment in both legs $(\mathrm{p}=0.03$, right leg, and $\mathrm{p}<0.001$, left leg).

Although the pathophysiological mechanism behind the decrease in leg volume at the four- to six-week examination was not completely evaluated the phenomenon is probably not due to a persisting disturbed bodily fluid balance after surgery, but is more likely a consequence of a negative nitrogen balance in the perioperative period causing decreased muscle mass. This finding implies that assessment four to six weeks after surgery is too early to reveal lymphedema. Yet it remains unclear whether the measurements at four to six weeks might predict development of lymphedema later on.

\section{Assessing clinical grading of lymphedema over time}

None of the participants were categorized with a higher grade of lymphedema than Grade 2 in any of the legs on any occasion of measurement. The distribution of the outcome of the clinical grading, leg-by-leg, in relation to the occurrence of lymphadenectomy is presented in Table 17.

Table 17. Clinical grading of the legs at baseline and after one year in relation to the occurrence of lymphadenectomy.

\begin{tabular}{|c|c|c|c|c|c|c|c|}
\hline & & \multicolumn{3}{|c|}{$\begin{array}{l}\text { Lymphadenectomy } \\
\qquad(n=116)\end{array}$} & \multicolumn{3}{|c|}{$\begin{array}{c}\text { No lymphadenectomy } \\
(n=118)\end{array}$} \\
\hline & Clinical grading & Baseline & One year & $p^{\#}$ & Baseline & One year & $p^{*}$ \\
\hline \multirow{3}{*}{ 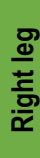 } & Grade 0 & $107(92.2 \%)$ & $92(80.7 \%)$ & 0.02 & $106(89.3 \%)$ & 95 (81.9\%) & 0.10 \\
\hline & Grade 1 & $8(6.9 \%)$ & $20(17.5 \%)$ & & $10(8.5 \%)$ & $14(12.1 \%)$ & \\
\hline & Grade 2 & $1(0.9 \%)$ & $2(1.8 \%)$ & & $2(1.7 \%)$ & $7(6.0 \%)$ & \\
\hline \multirow{3}{*}{ 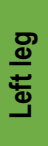 } & Grade 0 & $108(93.1 \%)$ & $91(79.8 \%)$ & $<0.01$ & $105(89.0 \%)$ & 95 (82.6\%) & 0.18 \\
\hline & Grade 1 & $8(6.9 \%)$ & $20(17.5 \%)$ & & $10(8.5 \%)$ & $16(13.9 \%)$ & \\
\hline & Grade 2 & -- & $3(2.6 \%)$ & & $3(2.5 \%)$ & $4(3.5 \%)$ & \\
\hline
\end{tabular}

Due to empty cells and/or a low expected number in a cell, the subgroups Grade 1 and Grade 2 were merged into one subgroup in the statistical analyses.

\# McNemar test.

At baseline, around $90 \%$ of the women were classified as Grade 0, independent of leg and lymphadenectomy. The grading did not differ between the legs on any occasion in the lymphadenectomy and non-lymphadenectomy groups. On the contrary, both legs revealed a significant increase in grading after one year in the lymphadenectomy group, but not in the nonlymphadenectomy group. This speaks in favor of a lymphedema-provoking effect of lymphadenectomy.

As BMI and leg volume were strongly correlated, the association between clinical grading and BMI was evaluated. BMI was classified according to the WHO classification [World Health Organization 2020]. The participants were divided into BMI classes and subdivided according to the clinical grade on the two occasions, baseline and one year (Table 18). 
Table 18. Associations between body mass index (in categories) and clinical grading of lymphedema

\begin{tabular}{|c|c|c|c|c|c|}
\hline \multirow[t]{2}{*}{ A } & \multirow[b]{3}{*}{ Clinical grading } & \multicolumn{4}{|c|}{ Baseline } \\
\hline & & & $\mathrm{BMI} \mathrm{C}$ & & \\
\hline Location & & Normal weight & Overweight & Obese & $p^{*}$ \\
\hline \multirow{3}{*}{ 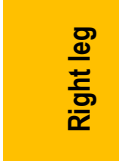 } & Grade 0 & $65(97.0 \%)$ & $72(94.7 \%)$ & $76(83.5 \%)$ & $<0.01$ \\
\hline & Grade 1 & $2(3.0 \%)$ & $4(5.3 \%)$ & $12(13.2 \%)$ & \\
\hline & Grade 2 & -- & -- & $3(3.3 \%)$ & \\
\hline \multirow{3}{*}{$\frac{\frac{\Phi}{\Phi}}{\frac{T}{\Phi}}$} & Grade 0 & $65(97.0 \%)$ & $74(97.4 \%)$ & 74 (81.3\%) & $<0.001$ \\
\hline & Grade 1 & $2(3.0 \%)$ & $2(2.6 \%)$ & $14(15.4 \%)$ & \\
\hline & Grade 2 & -- & -- & $3(3-3 \%)$ & \\
\hline
\end{tabular}

\begin{tabular}{|c|c|c|c|c|c|}
\hline \multicolumn{2}{|l|}{ B } & \multicolumn{4}{|c|}{ One year } \\
\hline \multirow[b]{2}{*}{ Location } & \multirow[b]{2}{*}{ Clinical grading } & \multicolumn{4}{|c|}{ BMI class } \\
\hline & & Normal weight & Overweight & Obese & $p^{*}$ \\
\hline \multirow{3}{*}{ 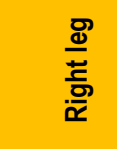 } & Grade 0 & $56(91.2 \%)$ & $68(81.0 \%)$ & $63(74.1 \%)$ & 0.026 \\
\hline & Grade 1 & $3(4.9 \%)$ & $13(15.5 \%)$ & $18(21.2 \%)$ & \\
\hline & Grade 2 & $2(3.3 \%)$ & $3(3.6 \%)$ & $4(4.7 \%)$ & \\
\hline \multirow{3}{*}{ 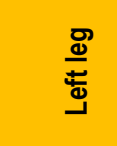 } & Grade 0 & $52(85.3 \%)$ & $70(83.3 \%)$ & $64(76.2 \%)$ & 0.319 \\
\hline & Grade 1 & $7(11.5 \%)$ & $12(14.3 \%)$ & $17(20.2 \%)$ & \\
\hline & Grade 2 & $2(3.3 \%)$ & $2(2.4 \%)$ & $3(3.6 \%)$ & \\
\hline
\end{tabular}

A- at baseline; B- at one year postoperatively.

Due to empty cells and/or a low expected number in a cell, the subgroups Grade 1 and Grade 2 were merged into one subgroup in the statistical analyses.

* Pearson Chi-squared tests $(\mathrm{df}=2)$

Clinical grade was significantly associated with BMI classes in both legs at baseline. The higher the BMI class the more likely it was that the clinical grading was higher than Grade 0 . This trend remained at the one-year assessment, but only for the right leg, whereas no such difference was observed for the left leg. Although none of the women had severe lymphedema it seemed that the obese women were more often encumbered with higher grades of lymphedema, even at baseline. This may raise questions about whether the grading system really discriminates between lymphedema and the subcutaneous fat deposits in the legs. If increasing BMI were a risk factor for lymphedema it would be expected that a larger proportion of the obese women would demonstrate higher grades in the clinical grading. The results may therefore bring into question the usefulness of clinical grading in evaluating lymphedema if the BMI is not taken into consideration. 


\section{Assessing the patient-reported leg swelling over time}

The distribution of the patient-reported degree of leg swelling for each leg in relation to the occurrence of lymphadenectomy and the occasion of assessment (baseline and one year after surgery) is demonstrated in Table 19.

At baseline, in the group of women in whom lymphadenectomy was not performed, a significantly higher proportion reported swelling of the left leg compared with the right leg $(\mathrm{p}=0.04)$, whereas no such difference was seen between the legs in the women who had lymphadenectomy. At the one-year assessment, no differences were observed in perceived swelling between the legs in the groups with and without lymphadenectomy. The reason for the discrepancy in perceived leg swelling at baseline is unclear. Supported by the fact that the BMI of the women without lymphadenectomy was significantly higher than the BMI of the women who had lymphadenectomy, and leg volume correlates strongly with BMI, the legs might have been perceived as heavier and more swollen in the women who did not have lymphadenectomy. However, this does not explain the difference between the legs at baseline or the lack of differences between the legs or lymphadenectomy groups at the one-year assessment.

The proportions of women with increased swelling of the legs between baseline and one year were significant for both legs in the lymphadenectomy group ( $p<0.0001$ in both legs), whereas only the difference between baseline and one year was significant in the right leg of women without lymphadenectomy ( $p=0.04$ ). When comparing the two groups (lymphadenectomy versus no lymphadenectomy) at baseline, no significant differences were observed in the degree of swelling for either of the legs. The corresponding comparison at the one-year assessment revealed a significantly higher proportion of swelling in the lymphadenectomy group $(p=0.01)$ in the right leg but no difference in the left leg. The reasons for the divergent outcomes between the right and left leg are unclear. They could be assumed to depend on inequity in leg size, but the volume estimation of the legs in this study (Figure 14) does not support this explanation.

As it is conceivable that BMI might influence the perception of swelling, the association between BMI classes and degree of swelling is presented in Table 20. 
Table 19. Association between patient-reported swelling of the legs at baseline and one year after surgery in relation to occurrence of lymphadenectomy.

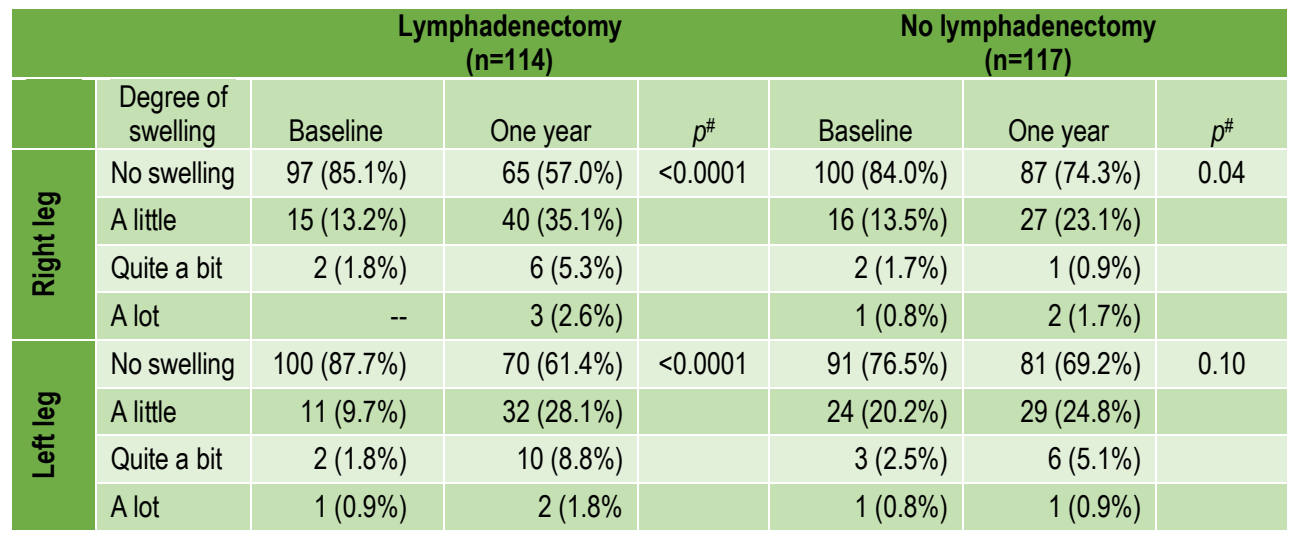

Due to empty cells and/or a low expected number in a cell, the subgroups Quite a bit and A lot were merged into one subgroup in the statistical between-group analyses. For analyses of the within-group effects, the subgroups were dichotomized into No swelling versus the swelling subgroups gathered together into one subgroup.

\# McNemar test.

Table 20. Association between categories of BMI and patient-reported swelling of the legs at baseline and one year after surgery

\begin{tabular}{|c|c|c|c|c|c|}
\hline \multicolumn{2}{|c|}{ Baseline } & \multicolumn{4}{|c|}{ BMI classes } \\
\hline \multirow{5}{*}{ 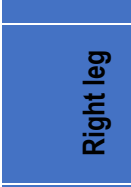 } & & Normal weight & Overweight & Obese & $p^{*}$ \\
\hline & No swelling & $63(94.0 \%)$ & $64(85.3 \%)$ & $70(76.9 \%)$ & 0.06 \\
\hline & A little & $3(4.5 \%)$ & $10(13.3 \%)$ & $18(19.8 \%)$ & \\
\hline & Quite a bit & $1(1.5 \%)$ & $1(1.3 \%)$ & $2(2.2 \%)$ & \\
\hline & A lot & -- & - & $1(1.1 \%)$ & \\
\hline \multirow{4}{*}{$\frac{\frac{\Phi}{\sigma}}{\frac{\Phi}{\Phi}}$} & No swelling & $61(91.0 \%)$ & $62(82.7 \%)$ & $68(74.7 \%)$ & 0.08 \\
\hline & A little & $5(7.5 \%)$ & $12(16.0 \%)$ & $18(19.8 \%)$ & \\
\hline & Quite a bit & $1(1.5 \%)$ & $1(1.3 \%)$ & $3(3.3 \%)$ & \\
\hline & A lot & -- & 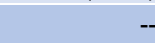 & $2(2.2 \%)$ & \\
\hline
\end{tabular}

\begin{tabular}{|c|c|c|c|c|c|}
\hline \multicolumn{2}{|c|}{ One year } & \multicolumn{4}{|c|}{ BMI classes } \\
\hline \multirow{5}{*}{ 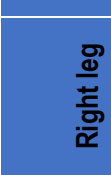 } & & Normal weight & Overweight & Obese & $p^{*}$ \\
\hline & No swelling & $42(67.7 \%)$ & $61(71.8 \%)$ & $49(58.3 \%)$ & 0.21 \\
\hline & A little & $18(29.0 \%)$ & $18(21.2 \%)$ & $31(36.9 \%)$ & \\
\hline & Quite a bit & $2(3.2 \%)$ & $3(3.5 \%)$ & $2(2.4 \%)$ & \\
\hline & A lot & - & $3(3.5 \%)$ & $2(2.4 \%)$ & \\
\hline \multirow{4}{*}{$\frac{\frac{\Phi}{\Phi}}{\frac{\bar{\sigma}}{\Phi}}$} & No swelling & $37(59.7 \%)$ & $62(72.9 \%)$ & $52(61.9 \%)$ & 0.43 \\
\hline & A little & $20(32.3 \%)$ & $17(20.0 \%)$ & $24(28.6 \%)$ & \\
\hline & Quite a bit & $4(6.4 \%)$ & $5(5.9 \%)$ & $7(8.3 \%)$ & \\
\hline & A lot & $1(1.6 \%)$ & $1(1.2 \%)$ & $1(1.2 \%)$ & \\
\hline
\end{tabular}

Due to empty cells and/or a low expected number in a cell, the subgroups Quite a bit and A lot were merged into one subgroup in the statistical analyses.

* Pearson Chi-squared tests $(\mathrm{df}=4)$. 
Although obese women seemed to have lower proportions of no swelling than normal weight women, the differences were not statistically significant. Consequently, it seemed that the perceived swelling of legs was independent of BMI.

\section{Agreement between methods of determining lymphedema}

The methods of determining lymphedema in relation to the occurrence of lymphedema are presented in the cross table (Table 21). High absolute agreements were found among all modalities, but when adjusted for the chance effect, most of the Cohen's kappa coefficients were low, below or equal to 0.40 , indicating poor agreement according to the interpretation of kappa coefficients by Fleiss et al. [Fleiss et al. 2003]. Only the methods BMI-standardized volume compared with crude volume reached a kappa coefficient that represented fair to good agreement beyond chance. One interpretation of this may be that the methods seem to measure different properties. In the absence of a gold standard as a reference test, it is important to pay attention to this issue. Several studies have been conducted comparing two methods of determining lymphedema [Hidding et al. 2016] but no comprehensive studies of several methods for determining lymphedema seem to have been conducted. Moreover, information on inter-rater agreement between the methods is scanty. Thus, the results of the present study contribute important information to the body of knowledge. 


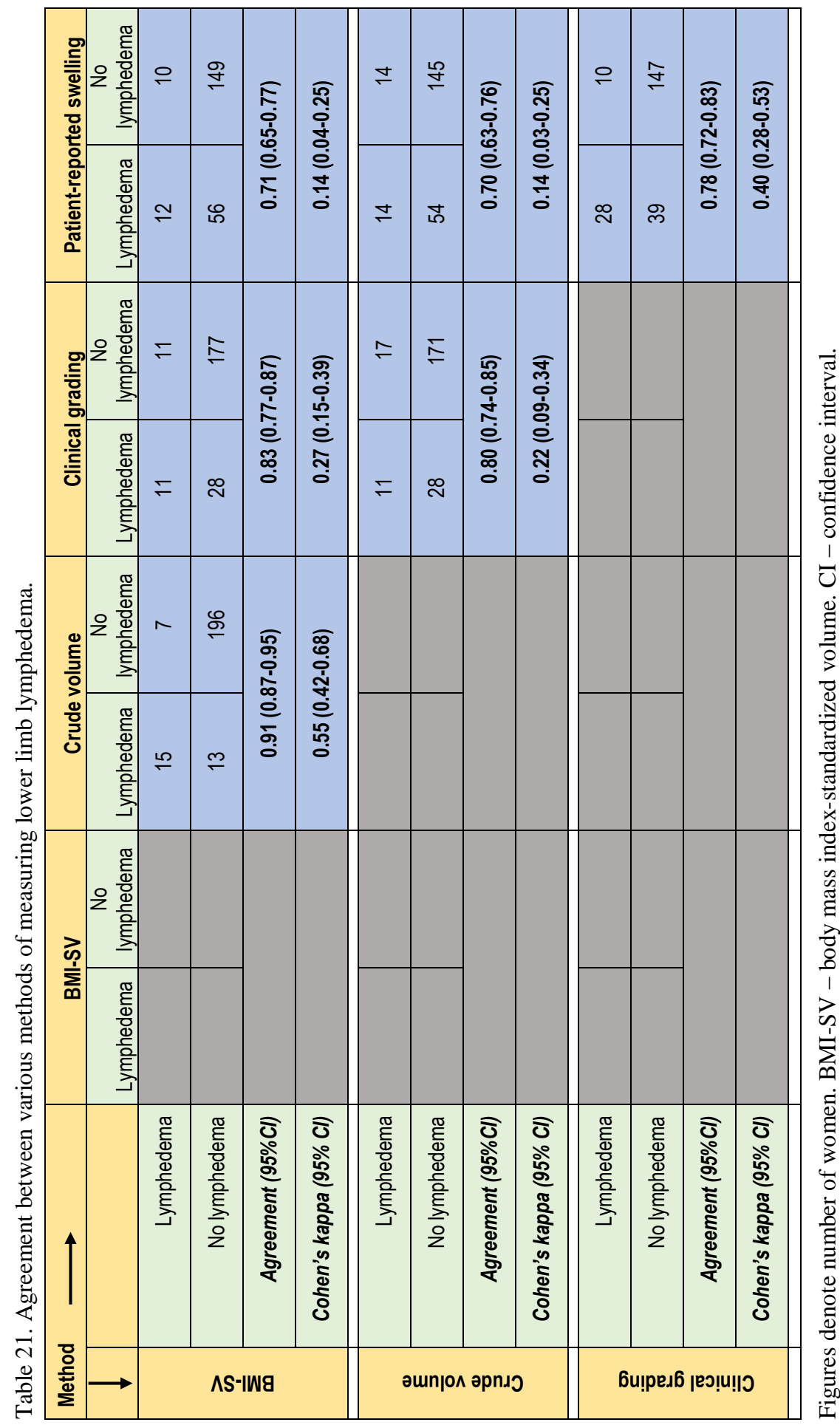




\section{Risk factors for lymphedema}

Since the incidence of lymphedema varies substantially depending on the methods by which it is assessed, risk factors may also vary. We therefore analyzed the clinical risk factor for each of the four methods for determining lymphedema separately: crude and BMI-standardized increase in leg volume, clinical grading, and patient-reported swelling. Multiple logistic regression using forward stepwise models was used to evaluate risk factors. The dependent variable was lymphedema (dichotomized as lymphedema or no lymphedema). Due to the sample size and consequently the restriction in the number of confounders to control for in the models, the risk factors were divided into preoperative factors and intra- and postoperative factors. All preoperative factors were initially entered into a multiple logistic regression forward stepwise model and the independent risk factors that were obtained in that model were entered into a second multiple logistic forward stepwise regression model. The second model included, besides the independent risk factors found in the first model, all intra- and postoperative factors. In order to ensure that the forward stepwise model did not express suppression effects of a variable, the model was controlled by a backward stepwise model building. To exclude a suppression effect it was requested that the models should demonstrate similar independent variables.

Separate multiple logistic regression models were finally used in order to assess risk factors associated with lymphadenectomy. These models were adjusted simultaneously, that is by using an all effect model building, for the independent risk factors found in the second models and factors that could influence lymphadenectomy (BMI, estimated bleeding volume, ASA classification, surgical method and mode of hysterectomy).

The pre-, intra- and postoperative factors are listed in Table 22. The outcomes of the multiple logistic forward stepwise models in relation to method of determining lymphedema are presented in Table 23. The risk factors were not unanimous when lymphedema was determined by different methods. Lymphadenectomy was a risk factor for lymphedema when assessed by BMI-standardized volume increase $\geq 10 \%$, clinical grading, and patient-reported swelling, but not when evaluated by crude volume increase $\geq 10 \%$. Aging was a risk factor for lymphedema when assessed by BMI-standardized volume increase $\geq 10 \%$ and patient-reported swelling, but not when assessed by crude volume increase $\geq 10 \%$ or clinical grading. Adjuvant radiotherapy was only a risk factor for lymphedema when assessed by BMI-standardized volume increase $\geq 10 \%$. Increase in BMI was a risk factor for lymphedema when estimated by crude volume increase $\geq 10 \%$ and patient-reported swelling, but not by BMI-standardized volume increase $\geq 10 \%$ or clinical grading. 
Table 22. Clinical variables divided into preoperative, and intra- and postoperative factors.

\begin{tabular}{|c|c|c|}
\hline \multirow{15}{*}{ 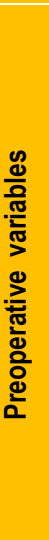 } & Age (years), mean (SD) & \\
\hline & BMI $\left.\left(\mathrm{kg} / \mathrm{m}^{2}\right)\right)$ classes & $18.5-24.9$ \\
\hline & & $25-29.9$ \\
\hline & & $\geq 30$ \\
\hline & ASA classification & Class I \\
\hline & & Class II \\
\hline & & Class III \\
\hline & Smoking & \\
\hline & Comorbidity: & Cardiac disease \\
\hline & & Diabetes mellitus \\
\hline & Previous surgery varicose veins & \\
\hline & Previous laparotomy & \\
\hline & Medication: & Diuretics \\
\hline & & Calcium antagonist \\
\hline & & NSAID \\
\hline \multirow{28}{*}{ 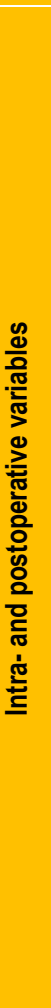 } & Surgical method: & Open surgery \\
\hline & & Minimal Invasive surgery \\
\hline & Hysterectomy mode & Simple hysterectomy \\
\hline & & Radical hysterectomy \\
\hline & Lymphadenectomy & \\
\hline & Surgery time (min), mean (SD) & \\
\hline & $\operatorname{EBV}(\mathrm{ml})$, mean (SD) & \\
\hline & FIGO stage & Stage $1 \mathrm{~A}$ \\
\hline & & Stage $1 \mathrm{~B}$ \\
\hline & & Stage 2 \\
\hline & & Stage $>2$ \\
\hline & Histology & Endometrioid grade 1-2 \\
\hline & & Endometrioid grade 3 \\
\hline & & Non-endometrioid \\
\hline & Tumor size >2 cm & No \\
\hline & & Yes \\
\hline & & No information available \\
\hline & Myometrial invasion $>50 \%$ & \\
\hline & Lymph node metastasis & \\
\hline & Clavien-Dindo classification* & Grade 0 \\
\hline & & Grade 1 \\
\hline & & Grade 2 \\
\hline & & $\geq$ Grade 3 \\
\hline & Adjuvant oncological treatment & No adjuvant therapy \\
\hline & & Radiation \\
\hline & & Chemotherapy \\
\hline & & Chemotherapy + radiation \\
\hline & $\Delta \mathrm{BMI}(\mathrm{kg} / \mathrm{m} 2)$, mean $(\mathrm{SD}) \S$ & \\
\hline
\end{tabular}

ASA - American Society of Anesthesiologist. BMI - body mass index. CI - confidence interval. EBV - estimated bleeding volume. NSAID - non-steroidal anti-inflammatory drugs. $\S \Delta \mathrm{BMI}=\mathrm{BMI}$ at one year $-\mathrm{BMI}$ at baseline. 
The contribution of comorbidity and medication to risk factors was rather inconsistent and was only found when lymphedema was determined by BMI-standardized volume increase and crude volume increase. The divergence in whether a factor was a risk factor or not for development of lymphedema when measured by different methods has not been highlighted before. Although most of the risk factors found in this study have been described as risk factors for lymphedema previously in different contexts, no studies have evaluated risk factors based on various methods of determining lymphedema in the same population. The discrepancy in risk factors between various methods of determining lymphedema raises the question of the usefulness of risk factors, and highlights the need for a "gold standard" method for determining lymphedema. Clinical grading demonstrated that lymphadenectomy was the only risk factor of the variables examined. This supports the opinion that clinical grading should not be used for determining risk factors for lymphedema. Likewise, crude volume increase seemed to suffer from the overshadowing influence of BMI on the risk factors as BMI outweighed strong and well-known risk factors for lymphedema, lymphadenectomy and radiation therapy. Therefore, leg volume should be BMI-standardized when used for assessing the occurrence of lymphedema.

The evaluation of risk factors associated with lymphadenectomy revealed major differences in risk factors depending on the method of assessing lymphedema (Table 24). While all investigated variables accounted for in Table 24 were found to be independent risk factors for lymphedema when lymphedema was determined by BMI-SV or patient-reported swelling, none of the variables were risk factors when lymphedema was determined by clinical grading, and only a single variable - proximal level of the lymphadenectomy - was a risk factor when assessed by crude volume.

This result strengths the opinion that determination of lymphedema by crude volume increase and clinical grading are inappropriate for determining risk factors for lymphedema. 


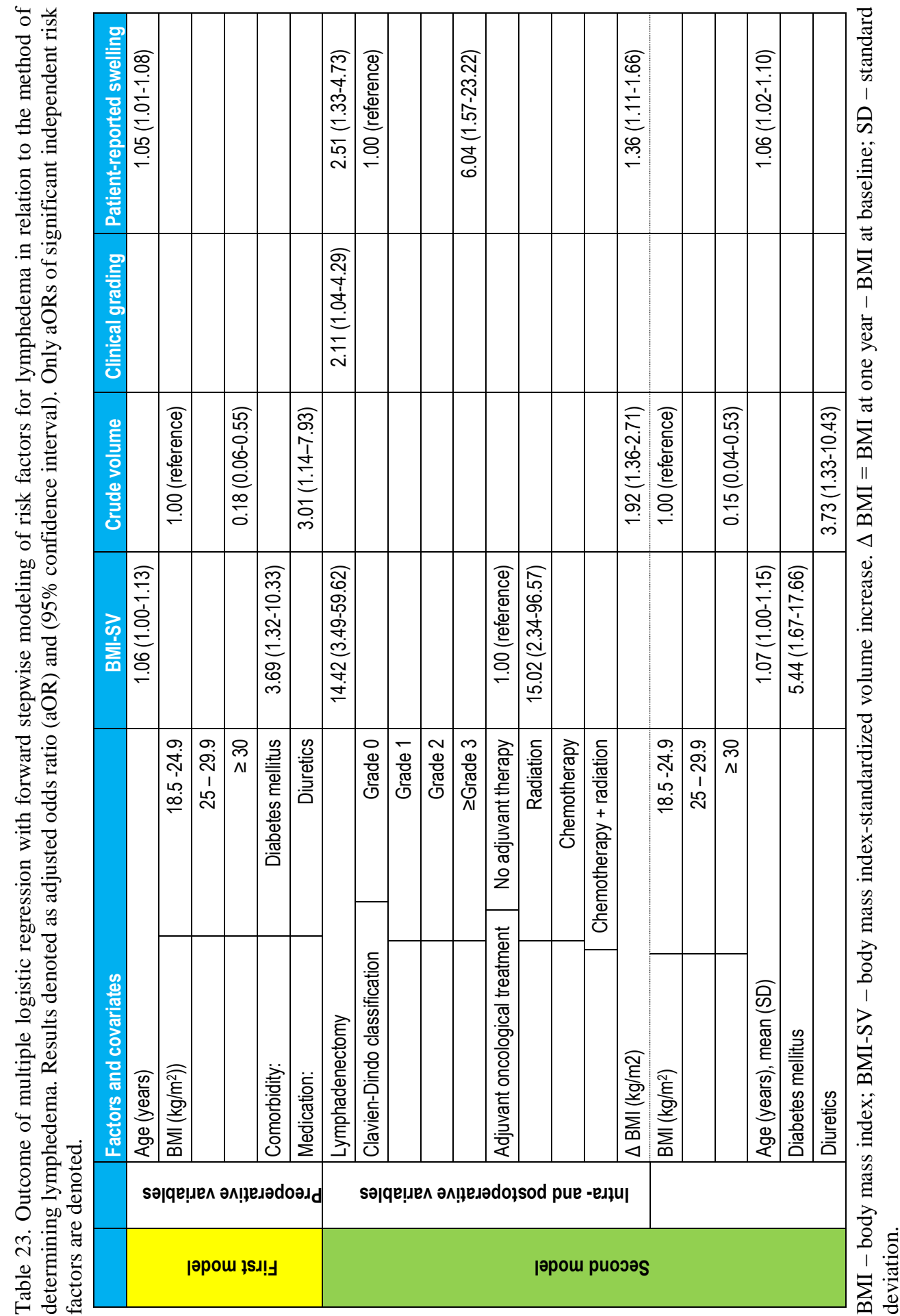




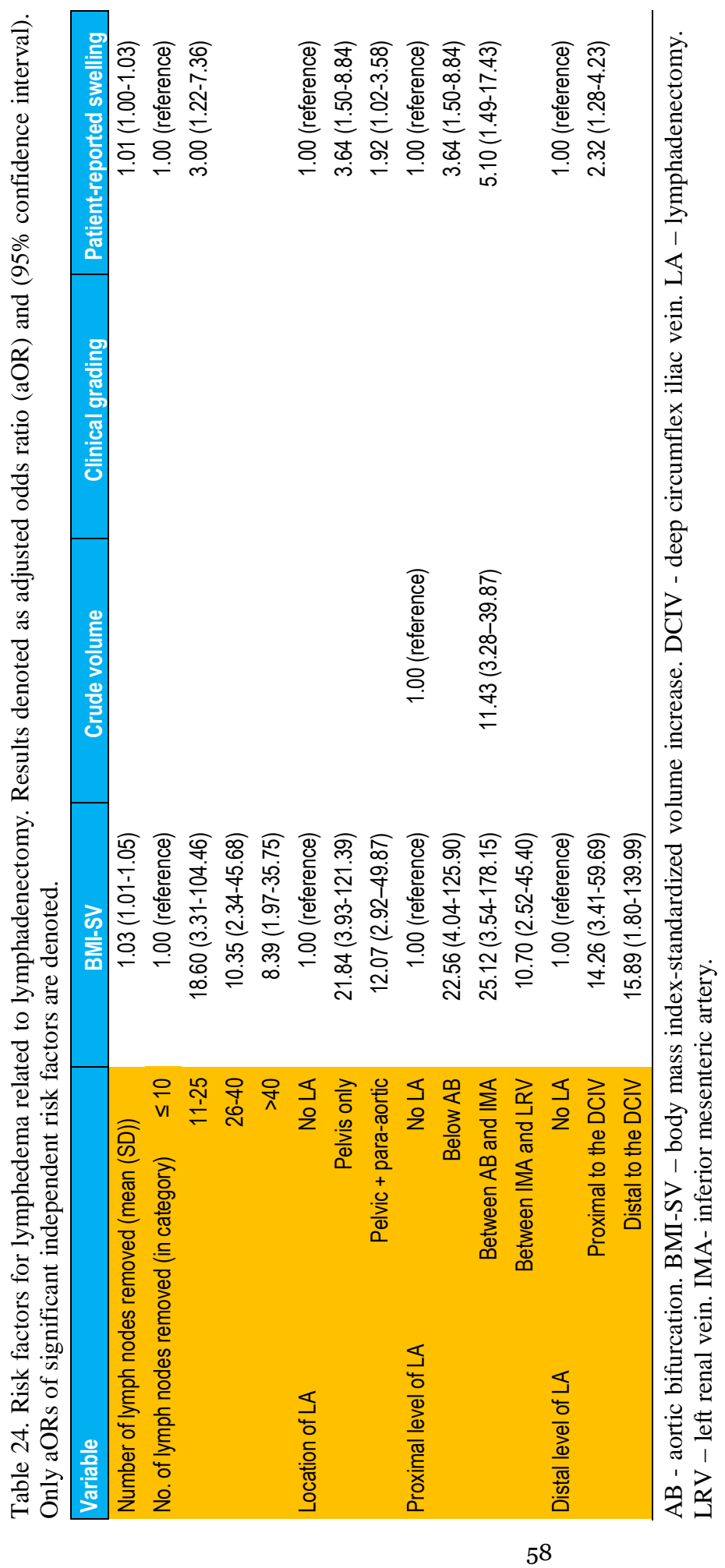




\section{Lymphocyst and lymphatic ascites}

The occurrence of lymphocyst and lymphatic ascites was assessed by vaginal ultrasonography. Lymphocyst was defined as encapsulated fluid in the pelvis or para-aortically, and lymphatic ascites was defined as free intra-abdominal liquid that did not show signs of hematomas or dissolved coagulated blood. The occurrence of lymphocyst and lymphatic ascites at the different times of assessment in relation to the occurrence of lymphadenectomy is shown in Table 25 . No lymphocysts were observed in any patient on any occasion when lymphadenectomy had not been performed, whereas nearly $10 \%$ of the women who had lymphadenectomy had lymphocysts four to six weeks after surgery.

Table 25. Occurrence of lymphocyst and lymphatic ascites detected by vaginal ultrasonography in relation to lymphadenectomy.

\begin{tabular}{|c|c|c|c|c|}
\hline \multirow[t]{2}{*}{$\begin{array}{l}\text { Timing of ex- } \\
\text { amination }\end{array}$} & \multicolumn{2}{|c|}{ Lymphadenectomy } & \multicolumn{2}{|c|}{ Non-lymphadenectomy } \\
\hline & Lymphocyst & Lymphatic ascites & Lymphocyst & Lymphatic ascites \\
\hline 4-6 weeks & $9.6 \%(11 / 116)$ & $42.2 \%(49 / 116)$ & $0 \%(0 / 119)$ & $4.2 \%(5 / 119)$ \\
\hline 6 months & $2.7 \%(3 / 112)$ & $9.8 \%(11 / 112)$ & $0 \%(0 / 113)$ & $0.9 \%(1 / 113)$ \\
\hline One year & $4.3 \%(5 / 116)$ & $3.4 \%(4 / 116)$ & $0 \%(0 / 118))$ & $0 \%(0 / 118)$ \\
\hline
\end{tabular}

More than half of the lymphocysts resolved spontaneously, and after one year, only $4 \%$ of the patients had remaining lymphocysts. These were asymptomatic and did not require treatment.

Lymphatic ascites was observed in more than $40 \%$ of women who had lymphadenectomy but even $5 \%$ of the women who did not undergo lymphadenectomy presented with lymphatic ascites four to six weeks after surgery. The lymphatic ascites resolved spontaneously before the six-month assessment in the vast majority, but remained in less than $4 \%$ of the women who had lymphadenectomy at the one-year evaluation. The reported incidence of lymphocysts and lymphatic ascites in the literature varies [Ghezzi et al. 2012, Zikan et al. 2015, Salehi et al. 2019]. The results of the present study demonstrate the dynamics of the lymphocysts and lymphatic ascites over time and illustrate the importance of describing the time frame in relation to surgery when reporting results of lymphocysts and lymphatic ascites as a substantial proportion resolves spontaneously. The high proportion of women with lymphadenectomy who developed lymphatic ascites is a warning sign of potential risks for serious complications associated with lymphatic ascites. Serious complications include among other intra-abdominal infection, symptomatic lymphatic ascites requiring paracentesis, or persistent symptomatic lymphatic ascites that does not respond to conservative treatment or paracentesis but requires surgery to stop the lymphatic leakage. 


\section{Impact of lymphadenectomy on HRQoL}

\section{Generic HRQoL measures}

The changes over time in the scores of the EQ-5D-3L, the LYMQOL global score, and the SF36 physical and mental component summaries are depicted in Figure 16.
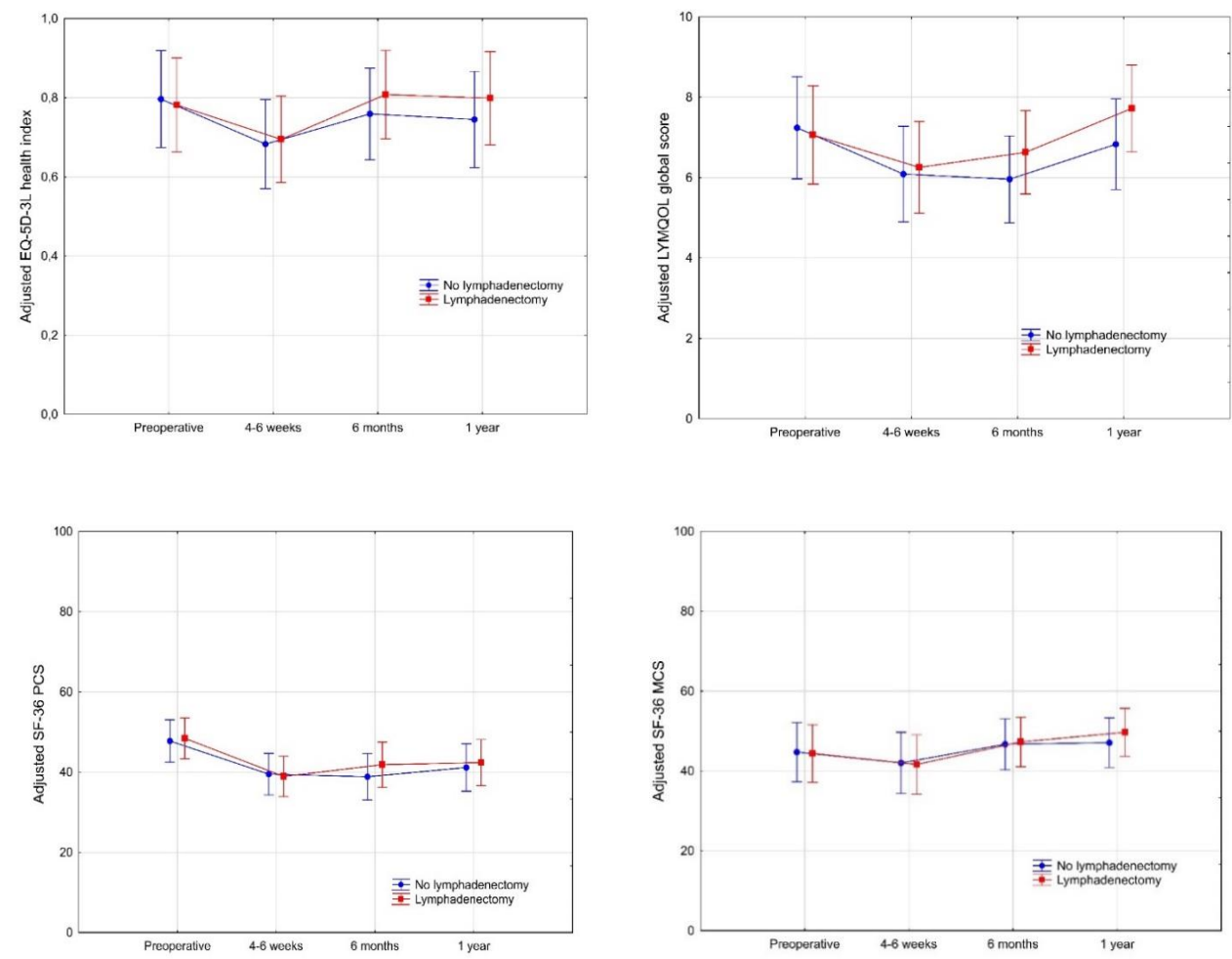

Figure 16. Outcome of EQ-5D-3L health index, LYMQOL global score, and SF-36 PCS and MCS on four occasions in relation to lymphadenectomy. Plots denote mean, and bars represent 95\% confidence interval. A higher score indicates better quality of life.

No significant differences were observed between the lymphadenectomy and no lymphadenectomy groups in the repeated measures ANOVA (Table 26). Only the SF-36 physical component summary revealed a significant effect over time with a significant reduction of the score over time, indicating worse quality of life concerning physical issues. The results indicate that variations with reduction of the HRQoL occurred during the treatment period, in particular within the first four to six weeks postoperatively. However, at the one-year follow-up the HRQoL had recovered to the preoperative level. 
Table 26. P-values of the repeated measures analysis of variance of the health-related quality of life assessments (EQ-5D-3L health index, SF-36, and LYMQOL) on four occasions in relation to lymphadenectomy.

\begin{tabular}{|c|c|c|c|c|}
\hline \multirow[b]{2}{*}{ HRQoL form } & & \multirow{2}{*}{$\begin{array}{c}\text { Between -LA and } \\
+ \text { LA groups } \\
\text { Main effect }\end{array}$} & \multicolumn{2}{|c|}{ Within-groups } \\
\hline & & & $\begin{array}{c}\text { Effect over } \\
\text { time* }\end{array}$ & $\begin{array}{c}\text { Interaction } \\
\text { effect }^{*}\end{array}$ \\
\hline \multirow[t]{2}{*}{ EQ-5D-3L health index } & Crude & 0.12 & 0.07 & 0.07 \\
\hline & Adjusted\# & 0.34 & 0.34 & 0.26 \\
\hline \multirow[t]{2}{*}{ SF-36 Physical component summary } & Crude & 0.19 & $<0.0001$ & $<0.01$ \\
\hline & Adjusted\# & 0.37 & $<0.01$ & 0.09 \\
\hline \multirow[t]{2}{*}{ SF-36 Mental component summary } & Crude & 0.44 & $<0.0001$ & 0.18 \\
\hline & Adjusted\# & 0.75 & 0.22 & 0.33 \\
\hline \multirow[t]{2}{*}{ LYMQOL Global score } & Crude & 0.39 & $<0.0001$ & $<0.01$ \\
\hline & Adjusted\# & 0.18 & 0.15 & 0.03 \\
\hline
\end{tabular}

LA - lymphadenectomy.

\# adjusted for mode for surgery (abdominal or minimal invasive surgery), complications according to Clavien-Dindo (grade 0, grade I, grade II, and grade III), adjuvant oncological treatment (no adjuvant therapy, chemotherapy, chemotherapy + radiation therapy, radiation therapy), and recurrence within one year (yes - no).

The outcomes of the eight subgroups of SF-36 over time are depicted in Figure 17
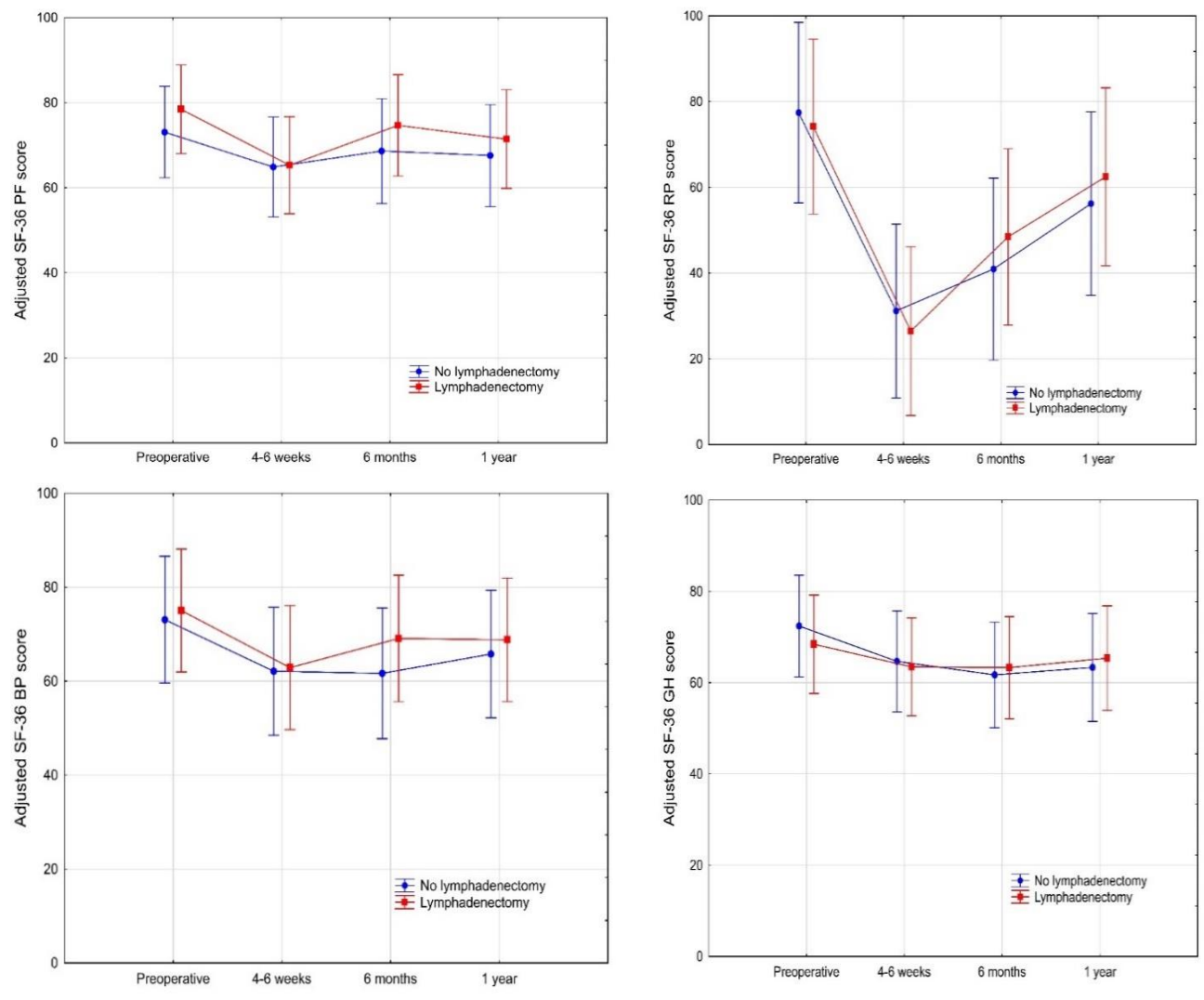

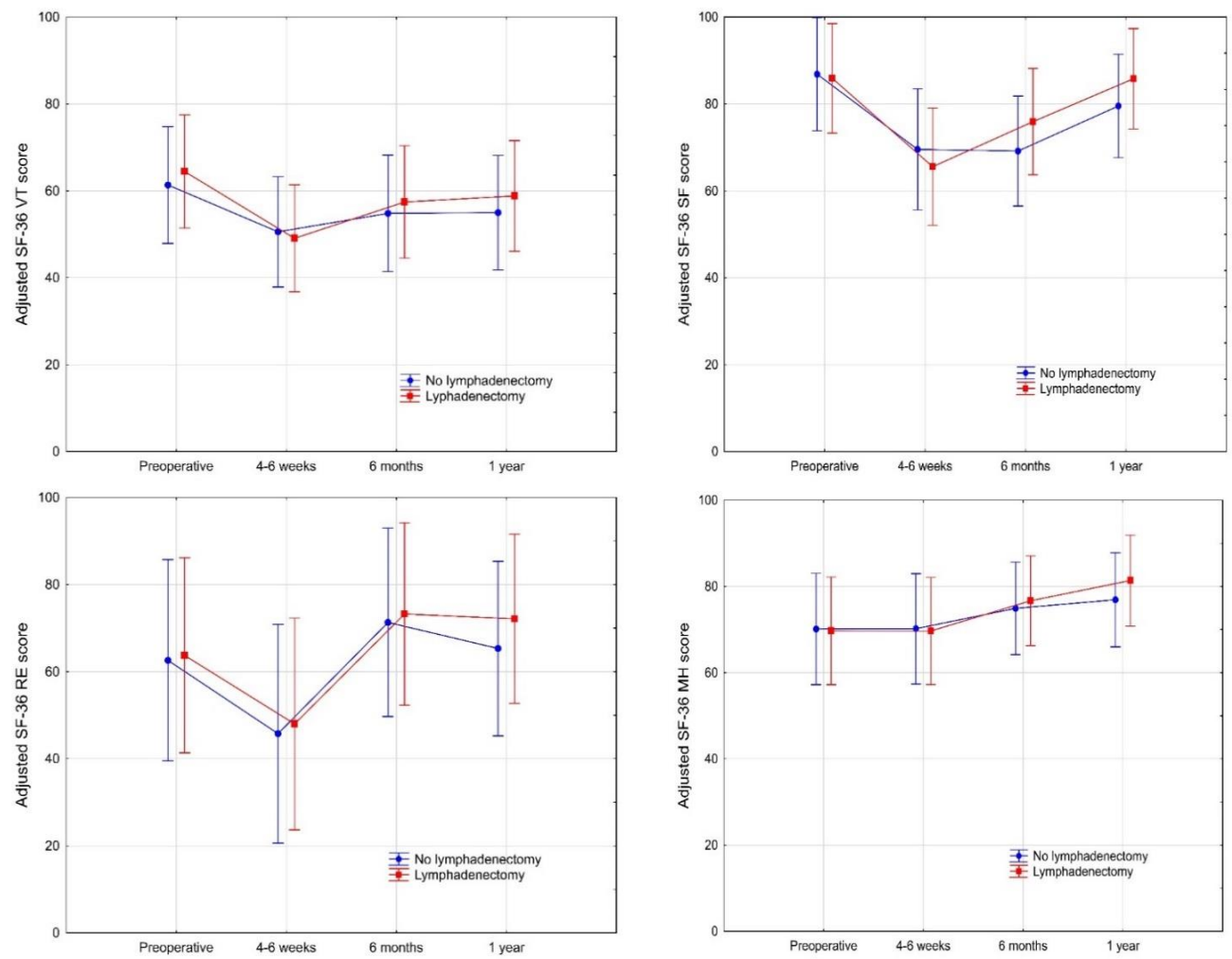

Figure 17. Outcomes of the eight SF-36 sub scales in relation to lymphadenectomy. Plots denote mean, and bars represent $95 \%$ confidence interval. Adjustment was made for mode for surgery, complications according to Clavien-Dindo, adjuvant oncological treatment, and recurrence within one year. A higher score indicates better quality of life.

No significant differences were seen between the groups in any of the eight subgroups of SF36, but significant effects over time were seen in PF, RP, VT, and SF indicating that these entities are particularly sensitive to the changes in HRQoL that may be influenced by lymphadenectomy.

\section{Lymphedema-specific HRQoL measures}

The outcomes of the four subscales of LYMQOL in relation to lymphadenectomy are presented in Figure 18. No differences were seen between the lymphadenectomy and no lymphadenectomy groups in any of the four subscales of LYMQOL, nor was any significant effect over time or interaction effect within the groups seen. Since LYMQOL is a lymphedema-specific instrument, the results may indicate that LYMQOL is not sufficiently sensitive to discriminate the HRQoL between lymphadenectomy versus no lymphadenectomy when the prevalence of lymphedema is in the range $10-30 \%$. 

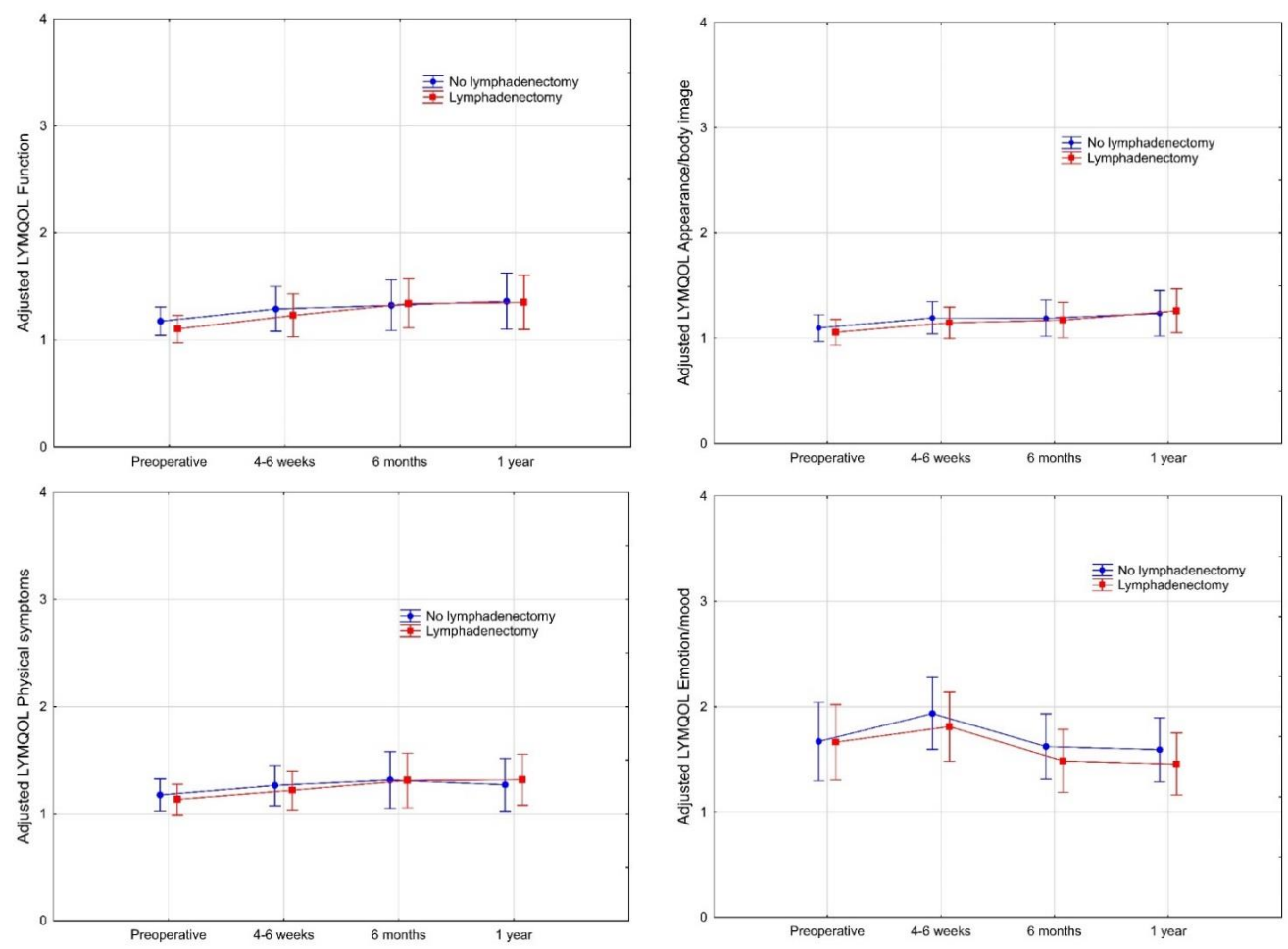

Figure 18. . Outcomes of the four LYMQOL subscales in relation to lymphadenectomy. Plots denote mean, and bars represent $95 \%$ confidence interval. Adjustment was made for mode for surgery, complications according to Clavien-Dindo, adjuvant oncological treatment, and recurrence within one year. A higher score indicates lower quality of life.

\section{Impact of lymphedema on HRQoL}

\section{Generic HRQoL measures}

The influence of lymphedema on HRQoL was based on the three methods of determining lymphedema: BMI-SV, clinical grading and patient-reported swelling. In the SF-36, only the two component summary scores were used. The changes in the various HRQoL scores from baseline to one year after surgery were used as independent variables and lymphedema was the dependent variable. None of the generic HRQoL scores, except the SF-36 PCS in the patientreported swelling, demonstrated significant differences between the women with lymphedema and those without lymphedema (Table 27). The SF-36 PCS in the patient-reported swelling category showed that the women with lymphedema, in particular those who had de novo swelling, had significantly lower scores $(p=0.04)$ after one year than at baseline.

In summary, the results imply that in the prevailing circumstances with the prevalence of lymphedema between $9.5 \%$ and $29.6 \%$, and only clinically low grade lymphedema, the HRQoL is not influenced. 


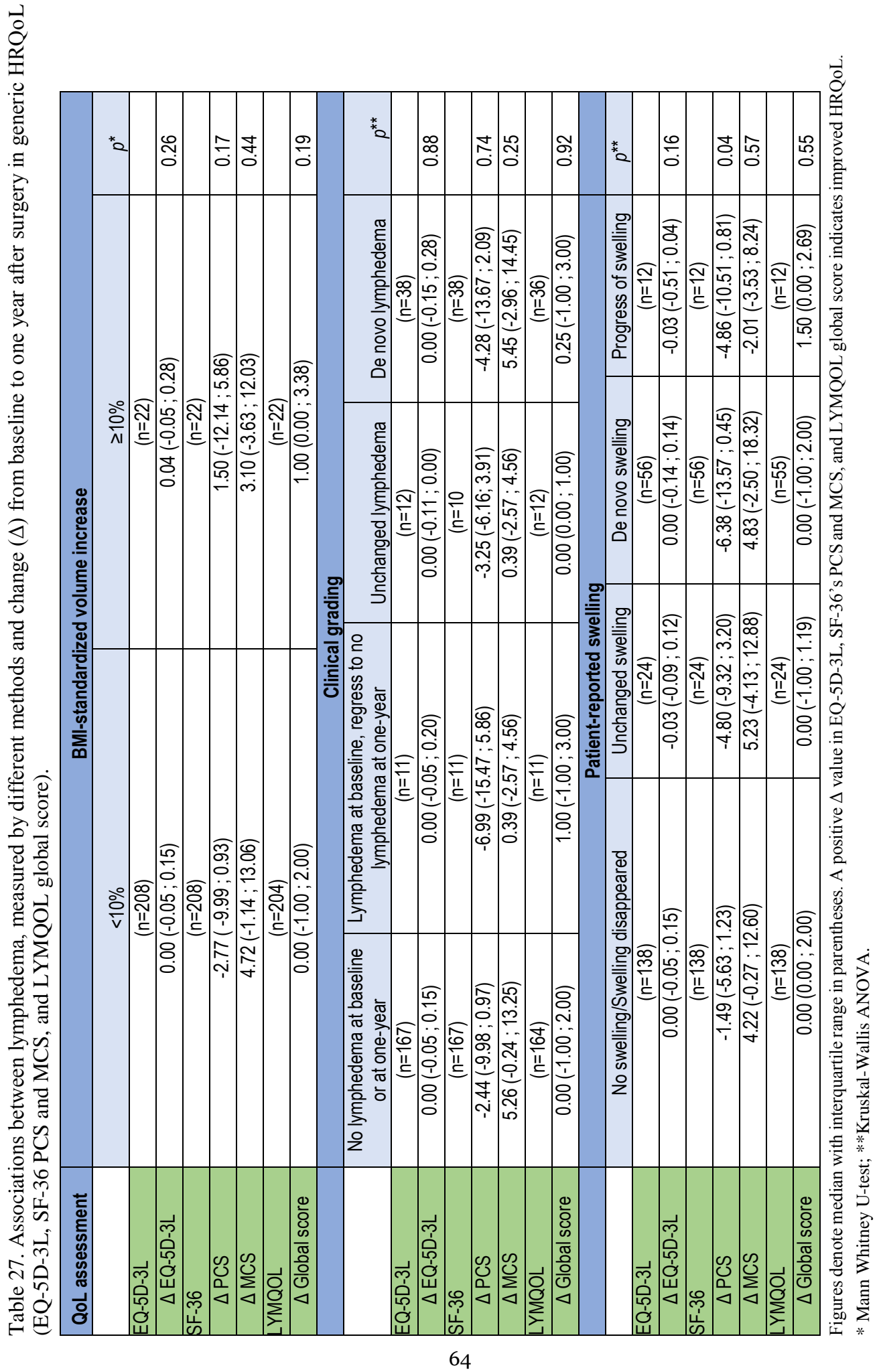




\section{Lymphedema-specific HRQoL measures}

The outcomes of the analyses of the lymphedema-specific HRQoL in relation to method of determining lymphedema are presented in Table 28. When lymphedema was assessed by BMIstandardized volume increase, significant differences were observed in the subscales Function and Appearance/body image. The women with lymphedema reported a poorer HRQoL than the women without lymphedema. No such differences were noted for the subscales Physical symptoms or Emotion/mood.

When lymphedema was assessed by clinical grading, the subscales Function, Appearance/body image and Physical symptoms but not Emotion/mood differed significantly. Compared with women without lymphedema, the women with lymphedema reported worse HRQoL. According to the post hoc tests, this was mainly attributed to de novo lymphedema in all three subscales ( $p<0.01, p<0.001$, and $p<0.001$, respectively).

Similar outcomes as in clinical grading were seen in the LYMQOL subscales when lymphedema was assessed as patient-reported swelling. The domains Function, Appearance/body image, and Physical symptoms differed significantly between those with reported swelling and those without. The post hoc analysis revealed that the differences were mainly attributed to those who had progress in swelling but also to those with de novo swelling $(p<0.001$, for all).

The findings concerning HRQoL and lymphedema support the literature that lymphedema affects HRQoL [Angiolo et al. 2013, Yost et al. 2014, Rowlands et al. 2014. Biglia et al. 2015, Kim et al. 2015]. The LYMQOL seems to be an inventory that even detects mild lymphedema and consequently is a sensitive instrument for detecting changes in lymphedema and discriminating between grades of lymphedema. This is further supported by the fact that the changes in LYMQOL subclass scores between baseline and one year were significantly associated with the clinical grading, as shown in Table 29.

Table 29. Association between clinical grade of lymphedema and change in scores of subclasses of LYMQOL.

\begin{tabular}{|l|c|c|c|c|}
\hline & Function & $\begin{array}{l}\text { Appearancel } \\
\text { body image }\end{array}$ & $\begin{array}{c}\text { Physical } \\
\text { symptoms }\end{array}$ & Emotion/mood \\
\hline Grade $0(n=176)$ & $0.00(0.00 ; 0.00)$ & $0.00(0.00 ; 0.00)$ & $0.00(0.00 ; 0.00)$ & $-0.33(-0.66 ; 0.00)$ \\
\hline Grade $1(n=39)$ & $0.00(0.00 ; 0.60)$ & $0.14(0.00 ; 0.43)$ & $0.20(0.00 ; 0.60)$ & $-0.17(-0.67 ; 0.17)$ \\
\hline Grade 2 $(n=9)$ & $0.25(-0.13 ; 0.28)$ & $0.07(-0.07 ; 0.64)$ & $0.19(0.00 ; 0.40)$ & $0.17(-0.50 ; 0.50)$ \\
\hline$p^{*}$ & $<0.001$ & $<0.001$ & $<0.01$ & 0.11 \\
\hline
\end{tabular}

Figures denote median and IQR.

* Kruskal-Wallis ANOVA 


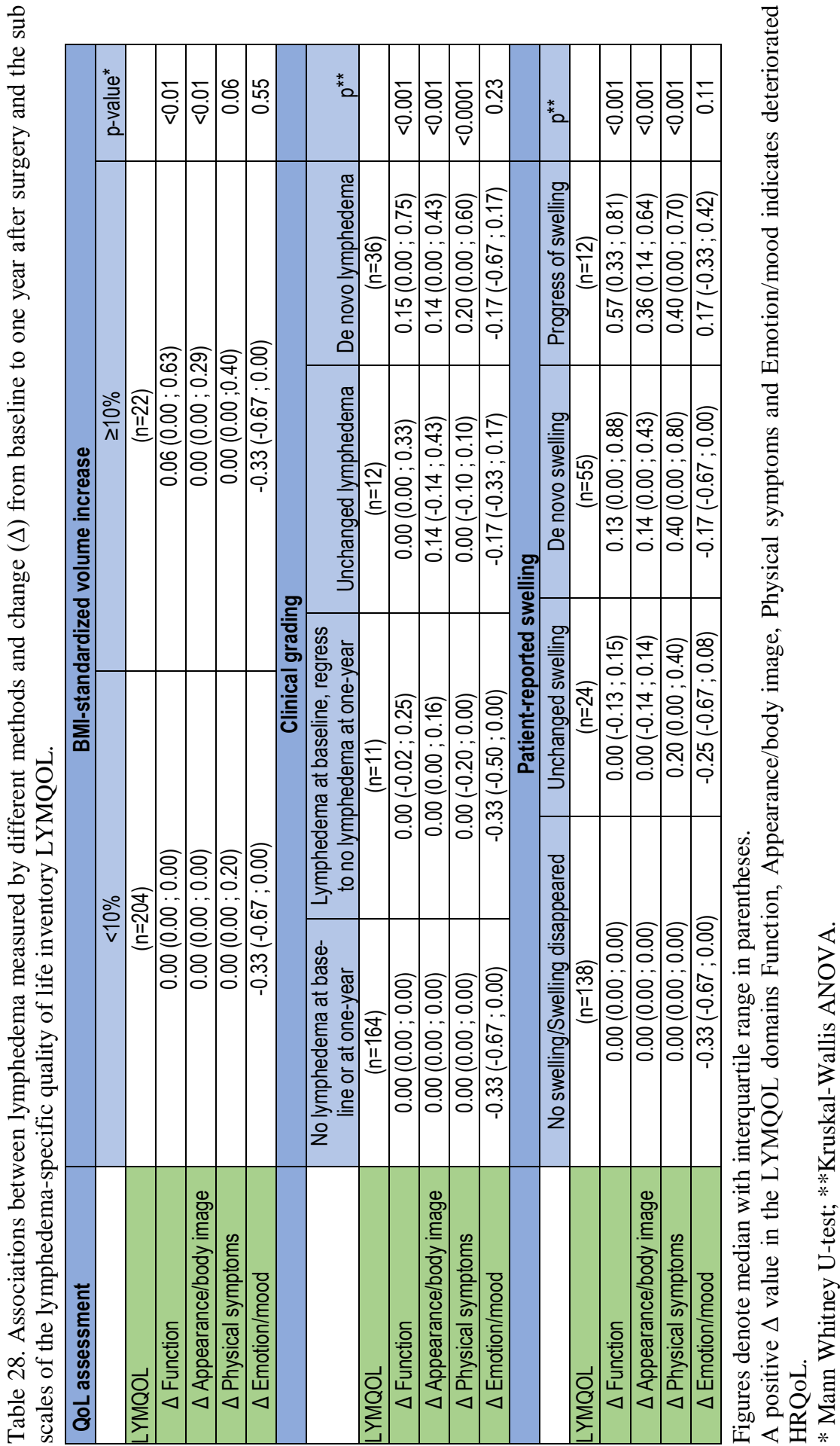




\section{Health economy}

\section{Hospital costs in relation to lymphadenectomy}

The specified hospital costs in relation to lymphadenectomy are presented in Table 30.

Table 30. Hospital costs, based on the list of cost per patient (CPP) year 2020 from the University hospital in Linköping, for treatment of women with endometrial cancer in relation to lymphadenectomy.

\begin{tabular}{|l|r|r|r|r|}
\hline Cost for & \multicolumn{1}{|c|}{$\begin{array}{c}\text { LA } \\
(\mathbf{n = 1 1 6 )}\end{array}$} & \multicolumn{1}{c|}{$\begin{array}{c}\text {-LA } \\
(\mathbf{n}=119)\end{array}$} & $\begin{array}{c}\text { Difference in } \\
\text { costs }\end{array}$ & $\begin{array}{c}\text { Relative in- } \\
\text { crease }\end{array}$ \\
\hline hospital stay & \multicolumn{1}{|c|}{$63,799(41,447)$} & $31,589(25,479)$ & 32,210 & $102 \%$ \\
\hline Surgery & $31.319(17,038))$ & $20,905(13,369)$ & 10,414 & $50 \%$ \\
\hline Post-anesthesia care unit & $6,564(849)$ & $5,812(957)$ & 752 & $13 \%$ \\
\hline Histopathology & $8,164(332)$ & $8,168(38)$ & -4 & $<1 \%$ \\
\hline Total for surgery & $109,845(39,402)$ & $66,480(26,923)$ & 43,365 & $65 \%$ \\
\hline Adjuvant chemotherapy & $43,184(35,796)$ & $4,881(18,257)$ & 38,303 & $785 \%$ \\
\hline Adjuvant radiotherapy & $16,882(36,062)$ & $9,404(28,199)$ & 7,478 & $80 \%$ \\
\hline Total for adj. oncologic treatment & $60,066(57,863)$ & $14,284(40,120)$ & 45,782 & $321 \%$ \\
\hline Unplanned outpatient visits & $2,106(2,609)$ & $1,071(2,140)$ & 1,035 & $97 \%$ \\
\hline Re-admissions (without surgery) & $1,899(6,284)$ & $1,111(3,899)$ & 788 & $71 \%$ \\
\hline Re-admissions (with surgery) & $4,590(15,010)$ & $1,790(9,638)$ & 2,800 & $156 \%$ \\
\hline Total for all treatment & $178,271(69,324)$ & $84,735(49,400)$ & 93,542 & $110 \%$ \\
\hline
\end{tabular}

Figures denote mean costs and (SD) in SEK.

$1 €=10.4867$ SEK and 1 US $\$=9.2037$ SEK.

LA - lymphadenectomy

The total costs for surgery increased substantially when lymphadenectomy was performed. For obvious reasons the group with lymphadenectomy (i.e., high-risk endometrial cancer) generated significantly higher costs for adjuvant oncologic treatment, and consequently the total hospital costs for all treatment were more than double for those who had lymphadenectomy compared with those without. The lymphadenectomy also generated higher costs for re-admissions and unplanned visits in health care facilities than the surgery without lymphadenectomy, indicating that lymphadenectomy is more likely to influence recovery and increase complications.

Mode of surgery influenced the costs, as demonstrated in Table 31 . The total costs for surgery of low-risk endometrial cancer without lymphadenectomy were $40 \%$ lower when performed by laparoscopy than by open surgery and $46 \%$ lower than when performed by robotic surgery. Moreover, robotic surgery was $46 \%$ more expensive than open surgery. The differences in total surgery costs between the modes of surgery were mainly influenced by the fixed robotic equipment cost of 27,336 SEK, which only affected the robotic group. Other contributing factors were the significantly longer hospital stay for open surgery compared with laparoscopic and robotic, while the time of surgery was significantly longer for laparoscopic surgery than for 
open and robotic surgery. In high-risk endometrial cancer, the total costs for surgery varied only minimally between the open and robotic groups. However, the cost for hospital stay was nearly double for the open surgery compared with the robotic due to a significantly longer hospital stay in the open surgery group. The cost for surgery was more than double for robotic surgery compared with open surgery although the operation time was almost the same. The larger cost for robotic surgery depended on the fixed robotic equipment cost, which only affected the robotic group.

The results showed that lymphadenectomy is cost-driving when compared with surgery without lymphadenectomy. Both the total costs for surgery and the total hospital costs nearly doubled when lymphadenectomy was performed, independent of the mode of surgery.

The results also revealed that one year after surgery of endometrial cancer there was no significant difference in HRQoL between the women who underwent lymphadenectomy and those who did not in the primary treatment of endometrial cancer. This indicates that lymphadenectomy cannot be considered as cost-effective in a cost-utility perspective. 


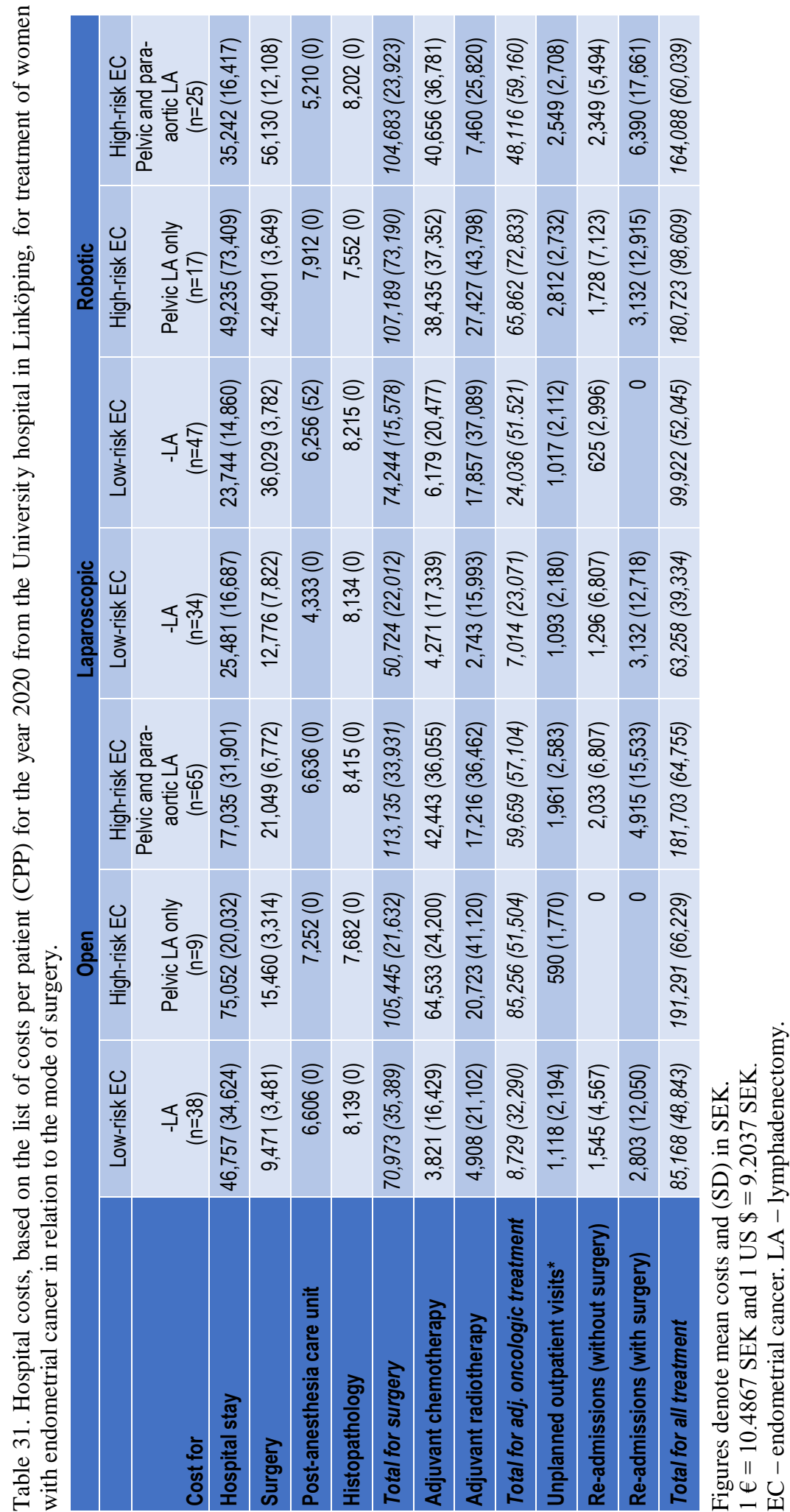




\section{Hospital costs in relation to lymphedema}

The hospital costs for lymphedema were estimated based on lymphedema determined by BMIstandardized volume increase $\geq 10 \%$ (Table 32 ).

Table 32. Hospital costs, based on the list of cost per patient (CPP) for the year 2020 from the University Hospital in Linköping, for treatment of women with endometrial cancer in relation to the occurrence of lymphedema.

\begin{tabular}{|l|r|r|r|r|}
\hline Cost for & $\begin{array}{c}\text { Lymphedema } \\
\text { (n22) }\end{array}$ & $\begin{array}{c}\text { No lymphedema } \\
\text { (n=209) }\end{array}$ & $\begin{array}{c}\text { Difference in } \\
\text { costs }\end{array}$ & $\begin{array}{c}\text { Relative in- } \\
\text { crease }\end{array}$ \\
\hline Hospital stay & $56,734(41,606)$ & $46,652(37,637)$ & 10,082 & $22 \%$ \\
\hline Surgery & $30,453(16,928)$ & $25,639(16,106)$ & 4,824 & $19 \%$ \\
\hline Post-anesthesia care unit & $6,599(854)$ & $6,145(977)$ & 454 & $7 \%$ \\
\hline Histopathology & $8,124(330)$ & $8,168(223)$ & -44 & $<1 \%$ \\
\hline Total for surgery & $101,910(38,446)$ & $86,606(40,235)$ & 15,304 & $18 \%$ \\
\hline Adjuvant chemotherapy & $23,100(34,611)$ & $23,621(34,095)$ & -521 & $-2 \%$ \\
\hline Adjuvant radiotherapy & $21,194(39,999)$ & $12,493(31,840)$ & 8,701 & $70 \%$ \\
\hline Total for adj. oncologic treatment & $44,294(55,331)$ & $36,114(54,912)$ & 8,180 & $23 \%$ \\
\hline Unplanned outpatient visits & $2,173(2,673)$ & $1,550(2,420)$ & 623 & $42 \%$ \\
\hline Re-admissions (without surgery) & $1,335(4,321)$ & $1,475(5,280)$ & -140 & $-9 \%$ \\
\hline Re-admissions (with surgery) & $9,682(21,021)$ & $2,293(10,835)$ & 7,389 & $322 \%$ \\
\hline Total for all treatment & $159,393(67,705)$ & $128,112(76,686)$ & 31,281 & $24 \%$ \\
\hline
\end{tabular}

Figures denote mean costs and (SD) in SEK

$1 €=10.4867$ SEK and 1 US $\$=9.2037$ SEK.

The total hospital costs for all treatments were nearly $25 \%$ higher for those who developed lymphedema compared with those who did not (Table 32). The higher hospital costs were mainly attributed to higher costs for the hospital stay, surgery, adjuvant radiation therapy, unplanned outpatient visits, and re-admissions with concomitant surgery. These results may indicate that efforts should be made to prevent lymphedema. The question raised by this study is whether lymphadenectomy can be justified based on health economic considerations. As lymphadenectomy contributes substantially to increased intra- and postoperative morbidity including lymphedema, which causes costs for the health care and impairs patients' HRQoL, lymphadenectomy cannot be considered as cost-effective in general. 


\section{General discussion}

\section{Methodological considerations}

The LASEC trial was designed as a prospective longitudinal observational study. This study design may be considered as a feasible and appropriate method to explore the impact of an intervention on outcome when randomization is not possible. Sometimes existing treatment recommendations or ethical considerations limit the possibility to randomize patients in a clinical trial, although a randomized controlled design would be the preferable method to explore the impact of an intervention and achieve a higher level of evidence.

In order to ensure a high quality of research, the LASEC trial complied with the requirements of the STrengthening the Reporting of Observational Studies in Epidemiology (STROBE) [Vandenbroucke et al. 2007] and the guidelines of Good Clinical Practice (GCP) [International Conference on Harmonisation 2002].

The LASEC trial focused on the effect of lymphadenectomy and the potential consequences of lymphadenectomy in terms of lymphedema and hospital costs. The rationale behind the LASEC trial was based on the requirements in the SNGEC from 2012 concerning lymphadenectomy in the treatment of high-risk endometrial cancer.

The methodology used in the LASEC trial has several strengths but also some limitations. The multicenter design made it possible to recruit women with low- and high-risk endometrial cancer and to complete the study within a reasonable time period. A strength of the study was that all participating clinics complied with the national guidelines. Although the exact number of surgeons was not accounted for in the trial, the surgery was conducted by several gynecological oncological surgeons according to the traditions of Swedish hospitals. Consequently, the surgery can be seen as reflecting the width of gynecological surgery in Sweden, and not a single center or single surgeon's work. In that way, the multicenter and multi-surgeon approach may contribute to the generalizability of the results.

As accounted for in the flow-chart of the study population (Figure 12), more than $60 \%$ of the women eligible for the study were either not asked to participate or there was logistic difficulties with time planning, or the study-specific staff were unavailable, making participation impossible. Although such loss of potential participants most likely was random, a selection mechanism cannot be completely ruled out. In order to evaluate whether the participating and non-participating groups were random, a comparison of clinical data between the groups would be appropriate. However, the descriptive and clinical information of the non-participating group in the LASEC trial was too deficient to give a meaningful evaluation. The lack of this information may be seen as a drawback that may restrict the interpretation of the results.

Approximately $20 \%$ of the eligible women declined to participate. In randomized clinical trials within cancer treatment, similar decline rates have been reported. [Jenkins et al. 2000]. Altru- 
ism, i.e., when someone acts to promote someone else's welfare, seemed to be a strong motivating factor for participating in clinical trials, independent of whether it was for benign or malignant diseases [Jenkins et al. 2000]. Thus, the relatively low number of women who declined to participate may be seen as a strength of the study.

More than $10 \%$ (27/262) of the included women were withdrawn from the study before termination of the one-year follow-up period, equally distributed between the lymphadenectomy and non-lymphadenectomy groups. Two women died due to progress of the cancer, seven were withdrawn by the investigator either due to lack of compliance or the investigator's misunderstanding of the study protocol when adjuvant therapy was required, and 18 women withdrew consent. Most of these 18 women had complications postoperatively and/or long recovery periods without regaining the strength or energy to continue participation. It cannot be excluded, that the withdrawn group constitutes a particular risk group for developing lymphedema or demonstrating impaired HRQoL. Thus, the remaining group of women that was analyzed may constitute a selected group that may have had a lower risk for development of lymphedema and impaired HRQoL. This can be seen as a limitation of the study.

To ensure good reliability of measurements, the participating lymphedema therapists conducted a test-retest evaluation of leg circumference measurements on a volunteer prior to the start of the trial. The vast majority of the lymphedema therapists conducted the test-retest measurements with an acceptable low deviation between the two measurements. Moreover, the recommendation in the study protocol that the measurements and clinical evaluations should preferably be conducted by the same lymphedema therapist on all occasions of evaluation, was essentially complied with. Both these issues should be seen as strengths of the study.

The lymphedema therapists were originally intended to be blinded to the occurrence of lymphadenectomy, but for obvious reasons it was very difficult to maintain this blinding since the very same lymphedema therapists also took care of the patients clinically in contexts outside the trial. Thus, in order to be optimal from a scientific point of view, the lymphedema therapist that performed the measures and the clinical lymphedema therapists should have been different persons. Due to limitations of staff and financial resources, this was not possible in the study.

Although it was stated in the protocol that compression stockings should be used when patients had complaints of leg swelling, it seemed that some lymphedema therapists prescribed or recommended compression stockings prophylactically if the patient had lymphadenectomy. Ideally, in order to estimate the true incidence of lymphedema, none of the participants should have used prophylactic compression stockings if these would have prevented the development of lymphedema. The latter is debated and questioned [Stuiver et al.2013, Rabe et al. 2018].

The follow-up period of one year may also be seen as a limitation since lymphedema may develop more than one year after treatment, although in most cases it develops within one year [Kuoppala et al. 2004, Abu-Rustum et al., 2006]. Thus, it is important to emphasize that the interpretation of the results should be restricted to one year postoperatively.

The use of volume increase as a measure of lymphedema is widespread in clinical practice and in research. However, the method is encumbered with drawbacks. As indicated by the results 
in this thesis a volume increase of the legs does not necessarily indicate extracellular fluid accumulation (i.e., lymphedema) but seems to be a summary effect of changes in fluid and tissue composition. BMI also seems to strongly influence volume increase. In order to avoid the effect of BMI, a BMI-standardized volume should be used when determining lymphedema and even progress in lymphedema.

Since there is no recommended 'gold standard` method to assess lymphedema, the LASEC trial used three methods for addressing lymphedema: two objective measures, volume increase and clinical grading, and a subjective measure, patient-reported swellings. All three methods are accepted for determining lymphedema in a clinical context [Brorson $\mathrm{H}$ et al. 2015, Executive Committee of the International Society of Lymphology 2020]. However, the results showed different incidences of lymphedema and different risk factors. It therefore may seem that the three methods address different aspects of lymphedema and that a comparison between the three methods is very difficult to interpret in a clinical context. From a scientific point of view the divergent results are troublesome to interpret and emphasize the need for a 'gold standard' method for measuring and assessing lymphedema and for determining risk factors for lymphedema.

To assess the impact on health-related quality of life, three validated instruments, the SF-36, and the EQ-5D-3L, which are generic health-related quality of life instruments, and the LYMQOL a lymphedema-specific instrument were used. The three instruments are validated and broadly used in a wide range of situations. Validation is fundamental in the assessment of HRQoL instruments to ensure that the instruments are correctly measuring what they are intended for.

The SF-36 was developed in the 1980s, sponsored by the RAND Company, and is widely used and considered as a 'gold standard for assessing generic HRQoL. The SF-36 has been validated in Sweden [Sullivan et al. 1995].

The EQ-5D-3L was developed by the EuroQol Group and has been used for more than 30 years in a wide range of conditions and populations. The EQ-5D-3L describes 243 potential health states, each of which can be attached to a numerical value, a health index, that reflects how good or bad a health state is according to the preference of the general population. The health index is widely used in economic evaluation of health care interventions, where the convention is to measure health gains as value-weighted time using quality-adjusted life years (QALYs). The EQ-5D-3L has been validated in Sweden [Burström et al.2001].

Several instruments have been described in the literature for measuring lymphedema-specific HRQoL [Cornelissen et al. 2018]. Only a few have been validated under Swedish circumstances. The LYMQOL was constructed by Professor Vaughan Keeley and co-workers at the Royal Derby Hospital, Derby, Derbyshire, England in 2010 [Keeley et al. 2010], and was found to be a simple and reliable instrument to use in clinical and scientific contexts. The LYMQOL is a self-reported questionnaire that covers various aspects of quality of life, categorized into four domains: function, body image/appearance symptom and mood. The LYMQOL has been validated in a Swedish context [Wedin et al. 2020]. In the Swedish validation there was an 
association between the domains in the LYMQOL and the perceived swelling of the legs. The LYMQOL has been validated in both Dutch and Turkish contexts [Van de Pas et al. 2016, Bakar et al. 2017] and has demonstrated a high correlation between generic HRQoL instruments and the domains of LYMQOL.

The majority of women that developed lymphedema in the LASEC study were clinically early stage lymphedema, and only a few had developed more severe lymphedema. This may limit the generalizability of the results to only account for corresponding stages of lymphedema. However, based on the results from the Swedish validation of LYMQOL and the corresponding Dutch and Turkish validations, this may imply that LYMQOL is actually a sensitive instrument for use with all stages of lymphedema.

In the analysis of risk factors, we initially identified clinically relevant factors that potentially could influence both exposure and outcome. The exposure was lymphadenectomy and the outcome was lymphedema as measured by the four methods: crude volume increase $\geq 10 \%$, BMIadjusted volume increase $\geq 10 \%$, clinical grading (de novo and increase in grading) and patientreported perception of swelling (de novo and increase in swelling).

The finding that BMI outweighed almost all other risk factors when assessing risk factors based on crude volume increase supported the consideration that a crude volume increase is an inappropriate method to determine lymphedema and risk factors. On the contrary, adjusting for BMI when assessing lymphedema gave risk factors for lymphedema that are recognized in the literature. Although the number of resected lymph nodes was a significant risk factor for lymphedema, it is important to emphasize that this cannot be translated into a sentinel node context since the sentinel node technique was not applied in the study.

Although the data were collected prospectively in a multicenter context, the costs were estimated retrospectively and based on the economic system from the university hospital of Linköping. The use of a catalog of price setting from an economic model is applied everywhere in the health care in all regions of Sweden. Likewise, the use of 'cost per patient' is an internationally accepted method to settle hospital costs.

Since the EQ-5D-3L health index did not differ between either between those who had lymphadenectomy and those do did not, nor between those with and without lymphedema, it was not meaningful to calculate QALY [The Pharmaceutical Benefits Board 2003]. Consequently, lymphadenectomy cannot be seen as cost-effective. 


\section{Conclusions}

One year after surgery of endometrial cancer

$>$ The incidence of lymphedema varied between $9.5 \%$ and $29.6 \%$, depending on the method of assessing lymphedema, with the highest incidence for patient-reported swelling and the lowest for volume determination.

$>$ The incidence of lymphedema was significantly higher in women who had lymphadenectomy compared with those without lymphadenectomy.

$>$ A not inconsiderable proportion of women without lymphadenectomy developed lymphedema, between $3.4 \%$ and $21.4 \%$, depending on the method of assessing lymphedema.

$>$ The inter-rater agreements, as described by Cohen's kappa, between the methods for determining lymphedema showed poor agreement, indicating that the methods may measure different conditions.

$>$ The lymphedema in most of the women who developed it was classified as mild.

$>$ Risk factors for lymphedema are not concordant when assessed by using different methods of determining lymphedema.

$>$ By using crude volume increase as the method for determining lymphedema, BMI was a strong risk factor that outweighed other well-established risk factors, indicating that volume increase measurement should be BMI-adjusted in order to determine incidence and risk factors for lymphedema.

$>$ Lymphadenectomy, age, diabetes mellitus and adjuvant radiation seemed to be independent risk factors for lymphedema.

$>$ The extent and location of lymphadenectomy were independent risk factors for lymphedema.

$>$ Lymphadenectomy per se did not influence the generic HRQoL.

$>$ Based on the incidence of lymphedema obtained from the various methods for determining lymphedema, the generic HRQoL did not differ between women with and without lymphedema, whereas the lymphedema-specific HRQoL as measured by the LYMQOL showed impaired quality of life, in particular in the domains function, appearance/body image, and physical symptoms, but not in emotion/mood.

$>$ Lymphadenectomy was a hospital cost-driving intervention, independent of mode of surgery.

$>$ Compared with no lymphedema, lymphedema was associated with increased postoperative morbidity and therefore increased hospital costs. 


\section{Reply to the hypotheses}

\begin{tabular}{|l|l|}
\hline Hypothesis & \multicolumn{1}{|c|}{ Reply } \\
\hline $\begin{array}{l}\text { Women with endometrial cancer treated with } \\
\text { surgery including lymphadenectomy have a } \\
\text { higher incidence of lymphedema compared } \\
\text { with those that do not receive lymphadenec- } \\
\text { tomy, both when measured subjectively and } \\
\text { objectively. }\end{array}$ & Confirmed \\
\hline $\begin{array}{l}\text { Risk factors for lymphedema are not con- } \\
\text { sistent when different methods to determine } \\
\text { lymphedema are used. }\end{array}$ & Confirmed \\
\hline $\begin{array}{l}\text { Women with endometrial cancer treated with } \\
\text { surgery including lymphadenectomy have } \\
\text { lower health-related quality of life compared } \\
\text { with those operated without lymphadenec- } \\
\text { tomy. }\end{array}$ & \\
\hline $\begin{array}{l}\text { Women with endometrial cancer treated with } \\
\text { surgery including lymphadenectomy are } \\
\text { more likely to develop complications, have } \\
\text { more re-admittance and therefore higher } \\
\text { health care costs compared with those that are } \\
\text { not exposed to lymphadenectomy. }\end{array}$ & Rejected \\
\hline
\end{tabular}




\section{Clinical implications}

- BMI-adjusted volume increase seemed to be a practical method to use for assessing lymphedema

- To assess HRQoL of lymphedema, both generic and lymphedema-specific instruments should be used.

- LYMQOL has been demonstrated to be a useful lymphedema-specific HRQoL instrument for all stages of lymphedema, and is easy to use.

- The selection of mode of surgery is relevant for the total hospital cost.

\section{Future perspectives}

The findings in this thesis highlight the problem of the lack of a 'gold standard method when assessing lymphedema. It is desirable to use a clinically tool specific for lymphedema. The lack of a 'gold standard' also applies for addressing the determination of risk factors for lymphedema.

The patient's perception of lymphedema compared with objectively measured lymphedema seemed to show the greatest discrepancy in occurrence of lymphedema. It seemed that lymphedema might be perceived earlier before a clinical examination or volume increase measurement would reveal it. Thus, patient-reported swelling might be a sensitive method for detecting lymphedema at subclinical levels. This phenomenon merits further exploration.

The findings in the thesis suggest that lymphedema not only developed in women who had lymphadenectomy, but also developed in a number of women who did not undergo lymphadenectomy. The pathophysiological mechanisms behind this phenomenon remain to be explained and need further investigation.

The study has revealed dynamics in postoperative leg volumes that have not been described previously in the literature. The impact of this phenomenon on development of lymphedema is not known and needs further research.

Lymphadenectomy was shown to be cost-driving for hospital costs. This raises both clinical and ethical questions on whether lymphadenectomy can be justified if lymphadenectomy or treatment-related consequences of lymphadenectomy do not increase survival. This issue needs to be further investigated. 


\section{Populärvetenskaplig sammanfattning}

\section{Lymfödem efter behandling av livmodercancer}

Livmodercancer är den vanligaste gynekologiska cancern bland kvinnor i Sverige och drabbar cirka 1500 kvinnor årligen. Prognosen är god då den oftast tidigt ger symtom som vaginal blödning efter klimakteriet och upptäcks därför som regel i ett tidigt stadium. Behandlingen av livmodercancer är i första hand med operation som innefattar borttagande av de gynekologiska organen.

Vissa typer av livmodercancer är förenat med sämre chans till överlevnad genom att de sprider sig i tidigare skede till lymfknutor. För denna grupp rekommenderas behandlingen även innefatta att man tar bort lymfknutor i buk och bäckenet för att kunna se i mikroskop om spridning har skett. Har spridning skett rekommenderas efter operation efterföljande fortsatt onkologisk behandling med strålning och/eller cellgifter.

Bedömning av om det föreligger en ökad risk för spridning av livmodercancern baseras sig på vilken typ av livmodercancer (histologi) det är samt växtsättet i livmodern. Vid ökad risk för tidig spridning och därmed sämre prognos klassas cancern som "hög-risk" livmodercancer och enligt de nationella riktlinjerna för livmodercancer från 2012 rekommenderas att vid operation förutom borttagande av de gynekologiska organen även ta bort lymfknutorna i bäckenet och längst stora kroppspulsådern. Vid avsaknad av den ökade risken för tidig spridning klassas cancern som "låg-risk" och lymfknututrymning avstås vid operationen.

Borttagande av lymfknutor innebär en risk för ökad sjuklighet för den drabbade kvinnan med utveckling av lymfödem i benen, ett tillstånd som oftast är kroniskt och som påverkar livskvaliteten negativt. Kunskapen om konsekvenserna av behandlingen av livmodercancer är idag begränsad, och det finns särskilt ett behov av ökad kunskap om utveckling av lymfödem och dess påverkan på livskvaliteten.

Avhandlingen baseras på en prospektiv observationsstudie, LASEC-studien (Lymphedema After Surgery of Endometrial Cancer). LASEC-studien pågick mellan 2014 och 2018; 15 sjukhus i Sverige deltog (nämnd i alfabetisk ordning: Eksjö, Falun, Gävle, Göteborg, Karlskrona, Karlstad, Linköping, Sundsvall, Skövde, Trollhättan, Umeå, Uppsala, Varberg, Västervik och Västerås).

Studien har till syfte att öka kunskap om lymfödem utveckling efter behandling av livmodercancer och på så sätt bidra till kunskap att kunna förbättra livskvaliteten för kvinnor som överlever livmodercancer.

Frågeställningarna som studien avser besvara är:

$>$ Vad är incidensen av lymfödem efter behandling av livmodercancer, med eller utan borttagande av lymfknutor?

> Hur påverkar lymfknututrymning och lymfödem livskvaliteten?

$>$ Vilka är riskfaktorerna för att utveckla lymfödem?

$>$ Vad innebär borttagande av lymfknutor och utveckling av lymfödem avseende kostnader för sjukvården? 
Det finns idag inget standardiserat sätt att mäta lymfödem. Hur vanlig lymfödemutveckling är, hur det påverkar livskvaliteten samt vilka riskfaktorer som finns är inte fastställda. I studier rapporteras att mellan 0 och $49 \%$ som behandlas för livmodercancer utvecklar lymfödem.

262 kvinnor med nydiagnostiserad livmodercancer inkluderades och 235 kvinnor fullföljde studien. 116 kvinnor med hög-risk cancer opererades med lymfknututrymning och 119 med lågrisk cancer opererades utan, i enlighet med rekommendationer från vårdprogrammet för livmodercancer från 2012.

Utvecklingen av lymfödem och värdering av livskvaliteten mättes vid tre tillfällen under ett år, samt innan operationen. Tre mätmetoder användes för värdering av lymfödem, två objektiva med omfångsmätning samt klinisk gradering och en subjektiv metod där den enskildes patients upplevelse av lymfödem uppskattades. Livskvaliteten värderades med tre olika livskvalitetsinstrument.

Resultaten visar att var tredje till femte kvinna drabbas av lymfödem efter behandling av livmodercancer. Livskvaliteten påverkas negativt vid lymfödemutvecklig. De starkaste faktorerna för risken att utveckla lymfödem verkar vara borttagandet av lymfknutor samt eventuell efterföljande strålbehandling. Både incidensen av lymfödem samt riskfaktorer varierar beroende av den mätmetod som används. Borttagande av lymfknutor är kostsamt för sjukvården.

Sammanfattningsvis är utvecklingen av lymfödem efter behandling av livmodercancer betydande och påverkar livskvaliteten. Studien visar att det finns ett behov av ett bra lymfödemspecifikt mätinstrument att använda i sjukvården samt inom forskning. 


\section{Acknowledgements}

Thank you all who have supported and contributed to enabling this thesis. In particular, I would like to thank:

All the participating women who unselfishly contributed to establishing new knowledge.

Professor Preben Kjølhede, my main supervisor. For your wisdom and oceans of patience and thank you for your unselfish way to contribute to my development in both clinical and academic aspects.

My co-supervisors Karin Stålberg, MD, PhD, Janusz Marcickiewicz, MD, PhD, Gabriel Lindahl, $\mathrm{MD}, \mathrm{PhD}$ and Ninnie Borendal Wodlin, $\mathrm{MD}, \mathrm{PhD}$. Thank you for great advise and contribution throughout the journey. It has been great getting to know you and I hope for future cooperation.

My co-authors Eva Ahlner, RPT, Åsa Åkesson, MD, Ulrika Ottander, MD, PhD, Tomas Davidson, $\mathrm{PhD}$, and Evelyn Lundin, $\mathrm{MD}, \mathrm{PhD}$, for great cooperation along the journey. It has been great getting to know you and I hope for future cooperation.

Associate professor Mats Fredriksson for your statistical advice. Anders Östberg for your economical expertise.

Associate professor Bergthor Björnsson and Associate professor Karin Johansson for commitment and contribution at the half-time seminar.

My team colleagues and friends, Evelyn Lundin, MD, PhD, Peter Lukas, MD, Shefqet Halili, MD, Charlotte Ginstman, MD, PhD and Guillermo Forfait, MD. Thank you all for supporting me. You are my role models. Moreover, to Evelyn, thank you for your contribution and for always being supporting when I need it.

Connie Kjølhede, thank you for your hospitality all these working evenings.

Associate professor Anna-Clara Spetz Holm MD, PhD, Associate professor Caroline Lilliecreutz MD, PhD, Associate professor Lena Nilsson, MD, PhD, Sofia Phil MD, PhD, and Sara Carlhäll MD, $\mathrm{PhD}$, for reviewing and sharing wise comments on the parts of the thesis.

The former head of the department of obstetrics and gynecology, at the University hospital in Linköping, Associate professor Ninnie Borendal Wodlin, $\mathrm{MD}, \mathrm{PhD}$, the present head of the department Associate professor Elizabeth Nedstrand, $\mathrm{MD}, \mathrm{PhD}$, and present chief physician of gynecology Associate professor Eva Uustal, $\mathrm{MD}, \mathrm{PhD}$, for giving me the opportunity to complete my thesis.

I would like to thank all my colleagues in department of obstetrics and gynecology, at the University hospital in Linköping for filling up for me when I have been absent from the clinic.

All colleagues in the participating centers involved in the study, and in particular all lymphedema therapists, for your commitment and devoted work.

The research nurse, Åsa Rydmark Kersley for keeping control of everything. 
Professor Vaughan Keeley, MD, PhD, for letting us use your work, the LYMQOL, enabling this study.

My present and former roomies and dear friends Emelie Wolgast, MD, PhD, Sofia Nevander, MD, Angeliki Piki, MD. Once a roomie, always a roomie.

Valerie Stålberg, MD, a dear friend, for long friendship, or trips and endless discussions about everything.

Ellinor Ekström and Eva Olèrs, my dear friends, for all the adventures throughout many stages in life. It takes a long time to get old friends.

Cecilia Lundgren and Linda Ärlehag, We started our medical journey together and I value our friendship. This journey I had to do without you, but I made popcorn!

The Arenius family, for long friendship and going through stages in life together.

My husband Christian Wedin, for all your love and support, and my children Linnea and Agnes, you are my everything. And to the rest of my family in Dalarna, my mother and father Kerstin and Brede Olsen, and my brother, Nicklas Rappendal with his family.

The study was supported by grants from Cancerfonden, the Medical Research Council of Southeast Sweden, Uppsala-Örebro Regional Research Council, the Scientific Council of the Region Halland, the County Council of Östergötland, and Lions forskningsfond mot folksjukdomar. 


\section{References}

Abu-Rustum NR, Alektiar K, Iasonos A, et al. The incidence of symptomatic lower-extremity lymphedema following treatment of uterine corpus malignancies: a 12-year experience at Memorial Sloan-Kettering Cancer Center. Gynecol Oncol. 2006;103(2):714-8.

Adanır SS, Bahşi İ. The giant anatomist, whose value is later understood: Bartolomeo Eustachi. Childs Nerv Syst. 2021;37(1), 1-4.

Al-Niamai F, Cox F. Cellulitis and lymphoedema: A vicious cycle. J Lymphoedema, 2009;4(2):38-42.

American Cancer Society, https://www.cancer.org/cancer/endometrial-cancer/causes-risks-prevention/risk-factors.html. (Accessed October 18, 2021)

American Physical Therapy Association. Guide to Physical Therapist Practice. Second Edition. American Physical Therapy Association. Phys Ther. 2001 81(1):9-746.

Angioli R, Plotti F, Cafà EV, et al. Quality of life in patients with endometrial cancer treated with or without systematic lymphadenectomy. Eur J Obstet Gynecol Reprod Biol. 2013;170(2):539-43.

Augustin M, Bross F, Földi E, et al. Development, validation and clinical use of the FLQA-I, a disease-specific quality of life questionnaire for patients with lymphedema. Vasa. 2005;34(1):31-5.

Bakar Y, Tuğral A, Özdemir Ö, et al. Translation and Validation of the Turkish Version of Lymphedema Quality of Life Tool (LYMQOL) in Patients with Breast Cancer Related Lymphedema. Eur J Breast Health. 2017;13(3):123-8.

Bansai N, Yendluri V, Wenham RM. The molecular biology of endometrial cancers and the implications for pathogenesis, classification, and targeted therapies. Cancer Control. 2009;16:8-13.

Beesley VL, Rowlands IJ, Hayes SC, et al. Australian National Endometrial Cancer Study Group. Incidence, risk factors and estimates of a woman's risk of developing secondary lower limb lymphoedema and lymphoedema-specific supportive care needs in women treated for endometrial cancer. Gynecol Oncol. 2015;136(1):87-93.

Bergström A, Pisani P, Tenet V, et al. Overweight as an avoidable cause of cancer in Europe. Int J Cancer. 2001;91(3):421-30. Erratum in: Int J Cancer. 2001;92(6):927.

Biglia N, Librino A, Ottino MC, et al. Lower limb lymphedema and neurological complications after lymphadenectomy for gynecological cancer. Int J Gynecol Cancer. 2015;25(3):521-5.

Biglia N, Zanfagnin V, Daniele A, et al. Lower Body Lymphedema in Patients with Gynecologic Cancer. Anticancer Res. 2017;37(8):4005-15.

Bokhman JV. Two pathogenetic types of endometrial carcinoma. Gynecol Oncol. 1983;15(1):10-7.

Bollinger A, Jäger K, Sgier F, et al. Fluorescence microlymphography. Circulation. 1981;64(6):1195-200. 
Bonnetblanc JM, Bédane C. Erysipelas: recognition and management. Am J Clin Dermatol. 2003;4(3):157-63.

Bonomi, A., Cella, DD, Hahn, EA, et al. Multilingual translation of the Functional Assessment of Cancer Therapy (FACT) quality of life measurement system. Quality of Life Research . 1996; 5: 309-20. (https://www.facit.org/measures/FACT-En)

Bourgeois P. Lymphoscintigraphy and Other Imaging Methods, In: Greene AK, Slavin SA, Brorson H (Eds). Lymphedema. Presentation, Diagnosis, and Treatment. Springer International Publishing, Switzerland, 2015, pp 157-84.

Brorson H. Volume measurements and follow-up., In: Greene AK, Slavin SA, Brorson H (Eds). Lymphedema. Presentation, Diagnosis, and Treatment. Springer International Publishing, Switzerland, 2015, pp 115-22.

Bruna J, Miller AJ, Beninson J. A simple clinical classification of lymphedema. Eur J Plast Surg. 1999;22:404-5.

Burström K, Johannesson M, Diderichsen F. Swedish population health-related quality of life results using the EQ-5D. Qual Life Res. 2001;10(7):621-35.

Calle EE, Rodriguez C, Walker-Thurmond K, et al. Overweight, obesity, and mortality from cancer in a prospectively studied cohort of U.S. adults. N Engl J Med. 2003;348(17):1625-38.

Carter J, Raviv L, Appollo K, et al. A pilot study using the Gynecologic Cancer Lymphedema Questionnaire (GCLQ) as a clinical care tool to identify lower extremity lymphedema in gynecologic cancer survivors. Gynecol Oncol. 2010;117(2):317-23.

Cheville AL, McGarvey CL, Petrek JA, et al. The grading of lymphedema in oncology clinical trials. Semin Radiat Oncol. 2003;13(3): 214-25.

Choi I, Lee S, Hong YK. The new era of the lymphatic system: no longer secondary to the blood vascular system. Cold Spring Harb Perspect Med. 2012;2(4):a006445.

Cornelissen AJM, Kool M, Keuter XHA, et al. Quality of Life Questionnaires in Breast Cancer-Related Lymphedema Patients: Review of the Literature. Lymphat Res Biol. 2018;16(2):134-9.

Cornish B. Bioimpedance analysis: scientific background. Lymphat Res Biol. 2006;4(1):47-50.

Dessources K, Aviki E, Leitao MM Jr. Lower extremity lymphoedema in patients with gynecologic malignancies. Int J Gynecol Cancer. 2020;30(2):252-260.

Deura I, Shimada M, Hirashita K, et al. Incidence and risk factors for lower limb lymphoedema after gynecologic cancer surgery with initiation of periodic complex decongestive physiotherapy. Int J Clin Oncol. 2015;20(3):556-60.

Drummond MF, Sculpher MJ, Claxton K, et al. Methods for the economic evaluation of health care programs. $4^{\text {th }}$ edition. Oxford University Press; Oxford, UK. 2015.

Dunberger G, Lindquist H, Waldenström AC, et al. Lower limb lymphedema in gynecological cancer survivors -effect on daily life functioning. Support Care Cancer. 2013;21(11):306370.

Döderlein A. Carcinoma uteri. In Döderlein A, Krönig B (eds): Operative Gynäkologie, $4^{\text {th }}$ edition. Thieme, Leipzig, Germany. 1921, pp. 574-670. 
Epstein E, Lindqvist PG, Geppert B, et al. A population-based cohort study on sun habits and endometrial cancer. Br J Cancer. 2009;101(3):537-40.

European Organization for Research and Treatment of Cancer Quality of Life Questionnaire: https://qol.eortc.org/questionnaires/. (Accessed September 15, 2021).

Executive Committee of the International Society of Lymphology. The diagnosis and treatment of peripheral lymphedema: 2020. Consensus Document of the International Society of Lymphology. Lymphology. 2020;53(1):3-19.

Fayers PM, Machin D. Quality of life. Assessment Analysis and Interpretation. $2^{\text {nd }}$ edition. John Wiley \& Sons, West Sussex, UK. 2000.

Finnane A, Hayes SC, Obermair A, et al. Quality of life of women with lower-limb lymphedema following gynecological cancer. Expert Rev Pharmacoecon Outcomes Res. 2011;11(3):287-97.

Fleiss JL, Levin B, Paik MC, et al. Statistical Methods for Rates and Proportions, s604. $3^{\text {rd }}$ edition. John Wiley\& Sons Inc. Hoboken, New Jersey, USA. 2003.

Geppert B. Sentinel node biopsy in endometrial cancer. Lund University, Faculty of Medicine. Doctoral Dissertation Series 2018:2. ISBN 978-91-7619-570-3. ISSN 1652-8220

Ghezzi F, Uccella S, Cromi A, et al. Lymphoceles, lymphorrhea, and lymphedema after laparoscopic and open endometrial cancer staging. Ann Surg Oncol. 2012;19(1):259-67.

Goyal P. Conventional Imaging Modalities for the diagnosis of Lymphedema. In: Greene AK, Slavin SA, Brorson H (Eds). Lymphedema. Presentation, Diagnosis, and Treatment. Springer International Publishing, Switzerland, 2015, pp 149-55.

Guermazi A, Brice P, Hennequin C, et al. Lymphography: an old technique retains its usefulness. Radiographics. 2003;23(6):1541-58; discussion 1559-60.

Haaverstad R, Nilsen G, Rinck PA, et al. The use of MRI in the diagnosis of chronic lymphedema of the lower extremity. Int Angiol. 1994;13(2):115-8.

Henderson BE, Casagrande JT, Pike MC, et al. The epidemiology of endometrial cancer in young women. Br J Cancer. 1983;47(6):749-56.

Hidaka T, Kato K, Yonezawa R, et al. Omission of lymphadenectomy is possible for low-risk corpus cancer. Eur J Surg Oncol. 2007;33(1):86-90.

Hidding JT, Viehoff PB, Beurskens CH, et al. Measurement Properties of Instruments for Measuring of Lymphedema: Systematic Review. Phys Ther. 2016;96(12):1965-81.

Hidding JT, Beurskens CHG, van der Wees PJ, et al. Changes in volume and incidence of lymphedema during and after treatment with docetaxel, doxorubicin, and cyclophosphamide (TAC) in patients with breast cancer. Support Care Cancer (2018) 26:1383-92

Hodgkinson K, Butow P, Hunt GE, et al. The development and evaluation of a measure to assess cancer survivors' unmet supportive care needs: the CaSUN (Cancer Survivors' Unmet Needs measure). Psychooncology. 2007;16(9):796-804.

Hussain MM. A proposed model for the assembly of chylomicrons. Atherosclerosis. 2000;148(1):1-15.

International Conference on Harmonisation of technical requirements for registration of pharmaceuticals for human use. ICH E6(R1): Guideline for Good Clinical Practice First 
published:01/07/2002. Available on: https://www.ema.europa.eu/en/documents/scientificguideline/ich-e6-r1-guideline-good-clinical-practice_en.pdf (Accessed September 14, 2021)

Jenkins V, Fallowfield L. Reasons for accepting or declining to participate in randomized clinical trials for cancer therapy. Br J Cancer. 2000;82(11):1783-8.

Kataru RP, Baik JE, Park HJ, et al. Regulation of immune function by lymphatic system in lymphedema. Front Immunol. 2019;10:470.

Keeley V, Crooks S, Locke J et al. A Quality of life measure for limb lymphedema (LYMQOL). J Lymphoedema. 2010;5(1):26-37.

Kim SI, Lim MC, Lee JS, et al. Impact of lower limb lymphedema on quality of life in gynecologic cancer survivors after pelvic lymph node dissection. Eur J Obstet Gynecol Reprod Biol. 2015;192:31-6.

Klernäs P, Johnsson A, Horstmann V, et al. Lymphedema Quality of Life Inventory (LyQLI)Development and investigation of validity and reliability. Qual Life Res. 2015;24(2):427-39.

Klernäs P, Kristjanson L.J, Johansson, K. (2010). Assessment of quality of life in lymphedema patients: Validity and reliability of the Swedish version of the Lymphoedema quality of life inventory (SLQOLI). Lymphology. 2010;43, 135-45.

Konno Y, Todo Y, Minobe S, et al. A retrospective analysis of postoperative complications with or without para-aortic lymphadenectomy in endometrial cancer. Int J Gynecol Cancer. 2011;21(2):385-90.

Kuoppala T, Tomás E, Heinonen PK. Clinical outcome and complications of laparoscopic surgery compared with traditional surgery in women with endometrial cancer. Arch Gynecol Obstet. 2004;270(1):25-30.

Larson DM, Johnson K, Olson KA. Pelvic and para-aortic lymphadenectomy for surgical staging of endometrial cancer: morbidity and mortality. Obstet Gynecol 1992;79(6):998-1001.

Lindqvist E, Wedin M, Fredrikson M, et al. Lymphedema after treatment for endometrial cancer - A review of prevalence and risk factors. Eur J Obstet Gynecol Reprod Biol. 2017;211:112-21.

Liu NF, Wang CG. The role of magnetic resonance imaging in diagnosis of peripheral lymphatic disorders. Lymphology. 1998;31(3):119-27.

Mendivil AA, Rettenmaier MA, Abaid LN, et al. Lower-extremity lymphoedema following management for endometrial and cervical cancer. Surg Oncol. 2016;25(3):200-4.

Mendoza N, Li A, Gill A, et al. Filariasis: diagnosis and treatment. Dermatol Ther. 2009;22(6):475-90.

Mitra D, Catalano PJ, Cimbak N, et al. The risk of lymphedema after postoperative radiation therapy in endometrial cancer. J Gynecol Oncol. 2016 Jan;27(1):e4.

Moffatt CJ, Franks PJ, Doherty DC, et al. Lymphoedema: an underestimated health problem. QJM. 2003;96(10):731-8.

Murali R, Soslow RA, Weigelt B. Classification of endometrial carcinoma: more than two types. Lancet Oncol. 2014;15(7):e268-78.

Natale G, Bocci G, Ribatti D. Scholars and scientists in the history of the lymphatic system. J Anat. 2017;231(3):417-29. 
Odicino F, Pecorelli S, Zigliani L, et al. History of the FIGO cancer staging system. Int J Gynaecol Obstet. 2008;101(2):205-10.

Paramanandam VS, Lee MJ, Kilbreath SL, et al. Self-reported questionnaires for lymphoedema: a systematic review of measurement properties using COSMIN framework. Acta Oncol. 2021;60(3):379-91.

Pavy JJ, Denekamp J, Letschert J. et al. EORTC late effects working group. Late effects toxicity scoring: the SOMA scale. Radiother Oncol. 1995;35(1):11-7. Addendum: LENT SOMA tables. Radiother Oncol. 1995;35(1):17-60.

Pecorelli S. Revised FIGO staging for carcinoma of the vulva, cervix, and endometrium. Int J Gynaecol Obstet. 2009;105(2):103-4. Erratum in: Int J Gynaecol Obstet. 2010;108(2):176.

Pigott A, Obermair A, Janda M, et al. Incidence and risk factors for lower limb lymphoedema associated with endometrial cancer: Results from a prospective, longitudinal cohort study. Gynecol Oncol. 2020;158(2):375-81.

Rabe E, Partch H, Hafner J, et al. Indications for medical compression stockings in venous and lymphatic disorders: An evidence-based consensus statement. Phlebology. 2018;33(3):163-84.

Ridner SH, Bonner CM, Doersam JK, et al. Bioelectrical impedance self-measurement protocol development and daily variation between healthy volunteers and breast cancer survivors with lymphedema. Lymphat Res Biol. 2014;12(1):2-9.

Rowlands IJ, Beesley VL, Janda M, et al. Quality of life of women with lower limb swelling or lymphedema 3-5 years following endometrial cancer. Gynecol Oncol. 2014;133(2):314-18.

Russo S, Walker JL, Carlson JW, et al. Standardization of lower extremity quantitative lymphedema measurements and associated patient-reported outcomes in gynecologic cancers. Gynecol Oncol. 2021;160(2):625-32.

Saito Y, Nakagasmi H, Kaneda Y, et al. Lymphedema and therapeutic lymphangiogenesis. Biomed Res Int. 2013;2013:804675.

Salehi S, Åvall-Lundqvist E, Brandberg Y, et al. Lymphedema, serious adverse events, and imaging 1 year after comprehensive staging for endometrial cancer: results from the RASHEC trial. Int J Gynecol Cancer. 2019;29(1):86-93.

Sitzia J, Sobrido L. Measurement of health-related quality of life of patients receiving conservative treatment for limb lymphoedema using the Nottingham Health Profile. Qual Life Res. 1997;6(5):373-84.

Sitzia J. Volume measurement in lymphedema treatment: examination of formulae. Eur J Cancer Care 1995;4(1):11-16.

Sleigh BC, Manna B. Lymphedema. [Updated 2021 Jun 4]. In: StatPearls [Internet]. Treasure Island (FL): StatPearls Publishing; 2021 Jan-. https://www.ncbi.nlm.nih.gov/books/NBK537239/ Last Update: June 4; 2021. (Accessed September 8, 2021).

Smoot BJ, Wong JF, Dodd MJ. Comparison of diagnostic accuracy of clinical measures of breast cancer-related lymphedema: area under the curve. Arch Phys Med Rehabil. .2011;92(4):603-10. 
SNGEC: Swedish National Guidelines for Endometrial Cancer [In Swedish:

Livmoderkroppcancer (endometrie-/corpuscancer. Nationellt vårdprogram] 2021.

https://kunskapsbanken.cancercentrum.se/globalassets/cancerdiagnoser/gynekologi/livmoderkroppscancer/vardprogram/nationellt-vardprogram-endometriecancer.pdf. (Accessed October 18, 2021).

Socialstyrelsen. Statistikdatabas för cancer [In Swedish]: https://sdb.socialstyrelsen.se/if_can/resultat.aspx. (Accessed October 18, 2021).

Stanton AW, Northfield JW, Holroyd B, et al. Validation of an optoelectronic limb volumeter (Perometer). Lymphology. 1997;30(2):77-97.

Stemmer R. A clinical symptom for the early and differential diagnosis of lymphedema. Vasa. 1976;5(3):261-2.

Stuiver MM, de Rooij JD, Nieweg OE, et al. No evidence of benefit from class-II compression stockings in the prevention of lower-limb lymphedema after inguinal lymph node dissection: results of a randomized controlled trial. Lymphology 2013:46(3):120-31.

Sullivan M, Karlsson J, Ware JE Jr. The Swedish SF-36 Health Survey--I. Evaluation of data quality, scaling assumptions, reliability and construct validity across general populations in Sweden. Soc Sci Med. 1995;41(10):1349-58.

Sun F, Skolny MN, Swaroop MN et al. The need for preoperative baseline arm measurement to accurately quantify breast cancer-related lymphedema. Breast Cancer Res Treat 2016;157(2):229-40.

Swedborg I. Voluminometric estimation of the degree of lymphedema and its therapy by pneumatic compression. Scand J Rehabil Med. 1977;9(3):131-5.

Swedish municipalities and regions (In Swedish: Sveriges Kommuner och regioner): Nationella KPP-principer, version 4. Kostnad-per-Patient. (Released 2020-06-15) https://webbutik.skr.se/sv/artiklar/nationella-kpp-principer-version-4.html (Accessed September 5, 2021)

Swedish Riksbank. Annual average exchange rates (aggregate). https://www.riksbank.se/en$\mathrm{gb} /$ statistics/search-interest--exchange-rates/annual-average-exchange-rates/ (Accessed September 5 2021).

Tanaka T, Ohki N, Kojima A, et al. Radiotherapy negates the effect of retroperitoneal nonclosure for prevention of lymphedema of the legs following pelvic lymphadenectomy for gynecological malignancies: An analysis from a questionnaire survey. Int J Gynecol Cancer 2007;17(2):460-4.

Taylor R, Jayasinghe UW, Koelmeyer $\mathbf{L}$, et al. Reliability and validity of arm volume measurements for assessment of lymphedema. Phys Ther. 2006;86(2):205-14.

The Pharmaceutical Benefits Board. Guidelines for economic evaluations from the Pharmaceutical Benefits Board (LFNAR 2003:2). 2003. https://www.tlv.se/download/18.2e53241415e842ce95514e9/1510316396792/Guidelines-for-economic-evaluationsLFNAR-2003-2.pdf (Accessed October 18, 2021).

Todo Y, Yamazaki H, Takeshita S, et al. Close relationship between removal of circumflex iliac nodes to distal external iliac nodes and postoperative lower-extremity lymphoedema in uterine corpus malignant tumors. Gynecol Oncol. 2015;139(1):160-4. 
Van de Pas CB, Biemans AA, Boonen RS, et al. Validation of the Lymphoedema Quality-ofLife Questionnaire (LYMQOL) in Dutch Patients Diagnosed with Lymphoedema of the Lower Limbs. Phlebology. 2016;31(4):257-63.

Vandenbroucke JP, von Elm E, Altman DG, et al. STROBE Initiative. Strengthening the Reporting of Observational Studies in Epidemiology (STROBE): explanation and elaboration. PLoS Med. 2007 Oct 16;4(10):e297.

Ward L, Winall A, Isenring E, et al. Assessment of bilateral limb lymphedema by bioelectrical impedance spectroscopy. Int J Gynecol Cancer. 2011;21(2):409-18.

Wedin M, Fredrikson M, Ahlner E, et al. Validation of the Lymphoedema Quality of Life Questionnaire (LYMQOL) in Swedish cancer patients. Acta Oncol. 2020;59(3):365-71.

Welter M, Rieger H. Interstitial fluid flow and drug delivery in vascularized tumors: a computational model. PLoS One. 2013 Aug 5;8(8):e70395.

World Health Organization. (1948) Constitution of the World Health Organization. Geneva, WHO Basic Documents. Forthy-fifth edition. Supplement. October 2006. https://www.who.int/governance/eb/who_constitution_en.pdf (Accessed October 18, 2021).

World Health Organization. BMI classification. http://www.euro.who.int/en/health-topics/disease-prevention/nutrition/a-healthy-lifestyle/body-mass-index-bmi. (Accessed October 18, 2021).

World Medical Association. WMA Declaration of Helsinki -Ethical Principles for Medical Research Involving Human Subjects. October 2013.Avaiable at: https://www.wma.net/policiespost/wma-declaration-of-helsinki-ethical-principles-for-medical-research-involving-humansubjects/ (Accessed September 14, 2021)

Yang X, Wang J. The Role of Metabolic Syndrome in Endometrial Cancer: A Review. Front Oncol. 2019 Aug 8;9:744.

Yoshihara M, Shimono R, Tsuru S, et al. Risk factors for late-onset lower limb lymphoedema after gynecological cancer treatment: A multi-institutional retrospective study. Eur J Surg Oncol. 2020;46(7):1334-8.

Yost KJ, Cheville AL, WeaverAL, et al. Development and validation of a self-report lowerextremity lymphedema screening questionnaire in women. Physical Therapy, 2013;93(5):694703.

Yost KJ, Cheville AL, Al-Hilli MM, et al. Lymphoedema after surgery for endometrial cancer: prevalence, risk factors, and quality of life. Obstet Gynecol. 2014;124(2 Pt 1):307-15.

Zikan M, Fischerova D, Pinkavova I, et al. A prospective study examining the incidence of asymptomatic and symptomatic lymphoceles following lymphadenectomy in patients with gynecological cancer. Gynecol Oncol. 2015;137(2):291-8. 


\section{Appendix}

Appendix 1. Case report file (CRF) circumferential measurement of lower limb. In Swedish: Mätning omfång nedre extremitet.

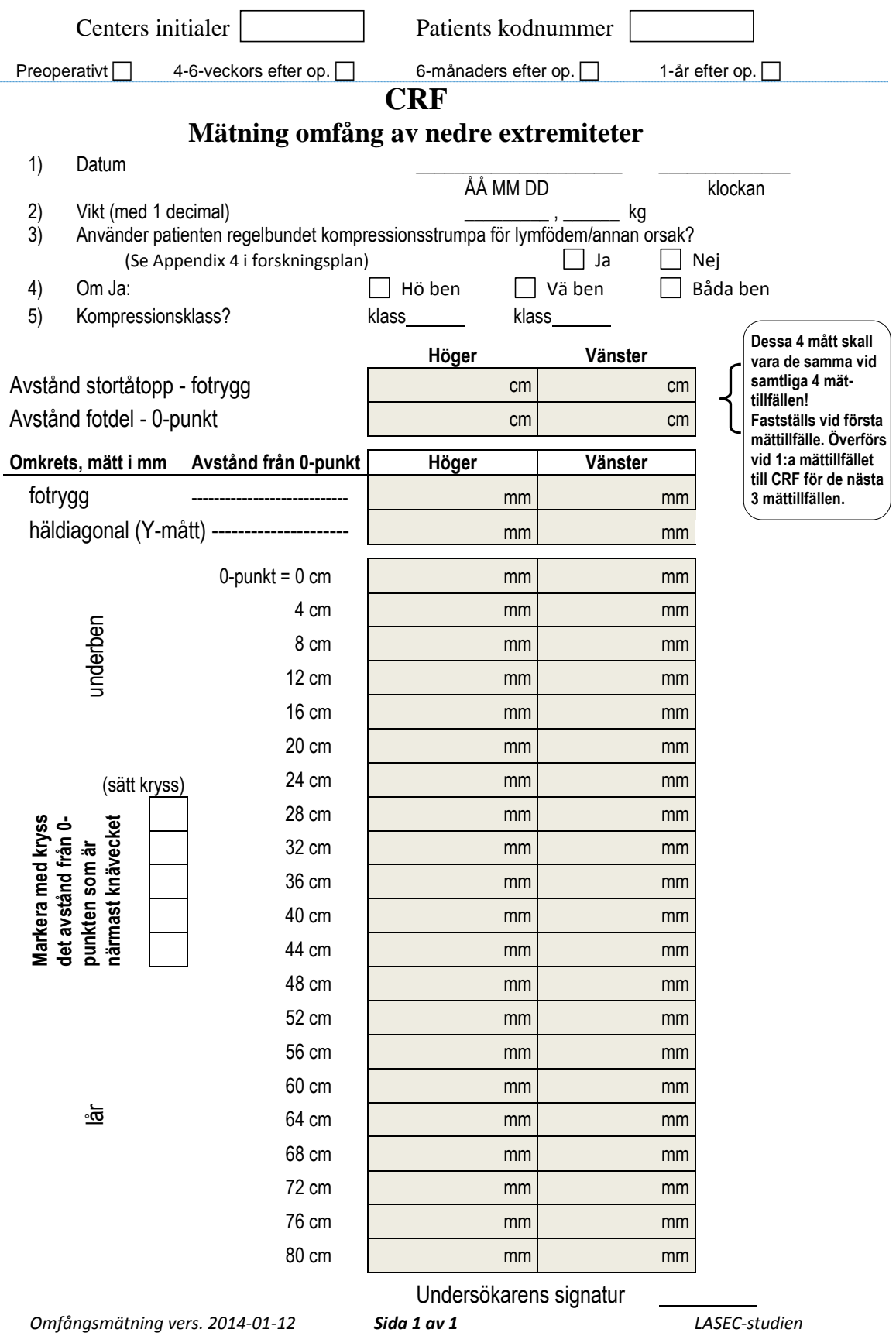


Appendix 2. The Swedish version of the LYMQOL (the leg version).

Datum för ifyllande:

\section{Frågeformulär angående lymfödem av ben och livskvalitet (LYMQOL)}

Instruktion:

I frågeformuläret finns 30 frågor. Vi ber Dig besvara frågorna genom att sätta en ring runt den siffra som Du anser passar bäst in på Dig. Med ben menar vi lår, knä och underben men inte fot.

Om Du vill ändra Ditt svar sätter Du en kryss över ringen:

Inte alls Lite

En hel del Mycket

\section{2}

och fyller sedan i rätta svaret:

(2) 3

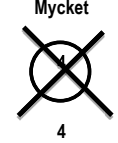

\begin{tabular}{|c|l|c|c|c|c|c|}
\hline Fråga nr & Fråga & Inte alls & Lite & En hel del & Mycket \\
\hline $\boldsymbol{A}$ & Upplever Du att höger ben är svullet? & 1 & 2 & 3 & 4 \\
\hline B & Upplever Du att vänster ben är svullet & 1 & 2 & 3 & 4 \\
\hline
\end{tabular}

Om Du har svarat Inte alls $i$ båda fråga A och B var god gå till Fråga 16. Om Du svarat ja $i$ endera var god försätt med fråga $n r 1$ och vidare

\begin{tabular}{|c|c|c|c|c|c|}
\hline 1 & \multicolumn{5}{|l|}{ Har Ditt / Dina svullna ben påverkat: } \\
\hline $1 a$ & - Din gångförmåga? & 1 & 2 & 3 & 4 \\
\hline $1 b$ & - Din förmåga att böja Dig för att t.ex. knyta skoband eller klippa tånaglar? & 1 & 2 & 3 & 4 \\
\hline 1c & - Din förmåga att stå? & 1 & 2 & 3 & 4 \\
\hline $1 d$ & - Din förmåga att resa Dig ur en stol? & 1 & 2 & 3 & 4 \\
\hline $1 e$ & - Din förmåga att sköta Ditt arbete? & 1 & 2 & 3 & 4 \\
\hline $1 f$ & - Din förmåga att utföra hushållsarbete? & 1 & 2 & 3 & 4 \\
\hline 2 & Påverkar bensvullnaden Dina fritidsaktiviteter/Ditt sociala liv? & 1 & 2 & 3 & 4 \\
\hline $2 a$ & \multicolumn{5}{|l|}{ Om ja, var god ge exempel på detta: } \\
\hline
\end{tabular}

\begin{tabular}{|c|c|c|c|c|c|}
\hline Fràga nr & Frảga & Inte alls & Lite & En hel del & Mycket \\
\hline 3 & I vilken utsträckning är Du beroende av andra människor? & 1 & 2 & 3 & 4 \\
\hline 4 & I vilken utsträckning känner Du att svullnaden påverkar Ditt utseende? & 1 & 2 & 3 & 4 \\
\hline 5 & I vilken utsträckning har Du svårigheter att hitta kläder som passar? & 1 & 2 & 3 & 4 \\
\hline 6 & I vilken utsträckning har Du svårigheter att hitta kläder som Du tycker om att ha på Dig? & 1 & 2 & 3 & 4 \\
\hline 7 & Har Du svårt att hitta sko som passar? & 1 & 2 & 3 & 4 \\
\hline 8 & Har Du svårt att hitta sockar, strumpor eller strumpbyxor som passar? & 1 & 2 & 3 & 4 \\
\hline 9 & Påverkar bensvullnaden Din självkänsla? & 1 & 2 & 3 & 4 \\
\hline 10 & Påverkar bensvullnaden Ditt förhållande till andra människor? & 1 & 2 & 3 & 4 \\
\hline 11 & Orsakar bensvullnaden smärta? & 1 & 2 & 3 & 4 \\
\hline 12 & Har Du domningar i Ditt / Dina svullna ben? & 1 & 2 & 3 & 4 \\
\hline 13 & Har Du stickningar eller pirrningar i Ditt / Dina svullna ben? & 1 & 2 & 3 & 4 \\
\hline 14 & Upplever Du svaghet i Ditt / Dina svullna ben? & 1 & 2 & 3 & 4 \\
\hline 15 & Upplever Du tyngdkänsla i Ditt / Dina svullna ben? & 1 & 2 & 3 & 4 \\
\hline \multicolumn{6}{|c|}{ Vid svar på de näste 7 frảgorna ska Du tänka hur det har varit under senaste veckan } \\
\hline 16 & Har Du haft svårt att sova? & 1 & 2 & 3 & 4 \\
\hline 17 & Har Du haft svårt att koncentrera Dig, t.ex. på att läsa? & 1 & 2 & 3 & 4 \\
\hline 18 & Har Du känt Dig spänd? & 1 & 2 & 3 & 4 \\
\hline 19 & Har Du känt Dig orolig? & 1 & 2 & 3 & 4 \\
\hline 20 & Har Du känt Dig lättretlig? & 1 & 2 & 3 & 4 \\
\hline 21 & Har Du känt Dig nedstämd? & 1 & 2 & 3 & 4 \\
\hline 22 & \multicolumn{5}{|c|}{ Sammantaget, hur skattar Du Din livkvalitet för närvarande? Var god markera med ring på nedanstående skalan. ( 0 = dâlig och 10 = utmärkt). } \\
\hline & 1 & 7 & & 9 & \\
\hline & Dâlig & & & \multicolumn{2}{|c|}{ Utmärkt } \\
\hline
\end{tabular}




\section{Papers}

The papers associated with this thesis have been removed for copyright reasons. For more details about these see:

http://urn.kb.se/resolve?urn=urn:nbn:se:liu:diva-180705 


\section{Department of biomedical and clinical sciences}

Linköping University Medical Dissertation No.1777, 2021

Linköping University

SE-581 83 Linköping, Sweden

www.liu.se 